\title{
Beryl Resources of
}

New Hampshire

GEOLOGIGAL SURVEY PROFESSIONAL PAPER 353

Prepared on behalf of the U.S. Atomic Energy Commission, and in part in cooperation with the New Hampshire State Planning and Development Commission

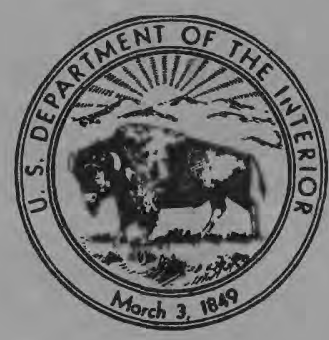




\section{Beryl Resources of \\ New Hampshire}

By JAMES J. PAGE and DAVID M. LARRABEE

GEOLOGICAL SURVEY PROFESSIONAL PAPER 353

Prepared on behalf of the U.S. Atomic Energy Commission, and in part in cooperation with the New Hampshire State Planning and Development Commission

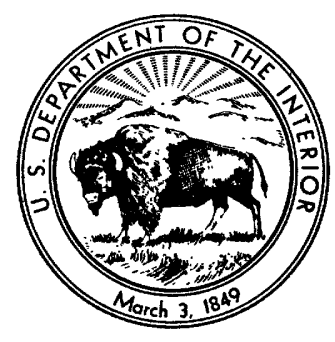

UNITED STATES GOVERNMENT PRINTING OFFICE, WASHINGTON : 1962 


\section{UNITED STATES DEPARTMENT OF THE INTERIOR}

STEWART L. UDALL, Secretary

GEOLOGIGAL SURVEY

Thomas B. Nolan, Director

The U.S. Geological Survey Library has cataloged this publication as follows :

\section{Page, James Jeffers, 1920-}

Beryl resources of New Hampshire, by James J. Page and David M. Larrabee. Washington, U.S. Govt. Print. Off., 1961 .

iii, 49 p. maps (part col,, part in pocket) tables. $31 \mathrm{~cm} . \quad$ (U.S. Geological Survey. Professional paper 353)

Prepared on behalf of the U.S. Atomic Energy Commission, and in part in cooperation with the New Hampshire State Planning and Development Commission.

Bibliography : p. 48-49.

(Continued on next card)

Page, James Jeffers, 1920-

Hampshire. 1961. (Card 2)

Beryl resources of New

1. Beryl. 2. Pegmatites. 3. Mines and mineral resources-New Hampshire. I. Larrabee, David Marcel, 1909- joint author. II. New Hampshire. State Planning and Development Commission. III. Title. (Series)

For sale by the Superintendent of Documents, U.S. Government Printing Office Washington 25, D.C. 


\section{CONTENTS}

Abstract.........

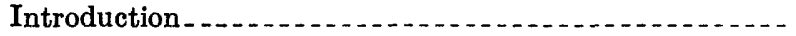

Beryl mining, production, and uses..................

Internal structure and mineralogy of pegmatites........ -

Methods used in estimating resources . . . . . . . . . .

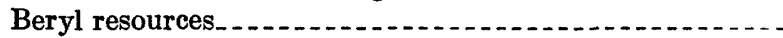

Description of pegmatites_...

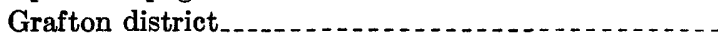

Palermo No. 1 mine............

Keene district.........................

Beryl Mountain mine....................

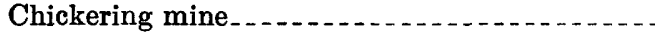

Raymond region...

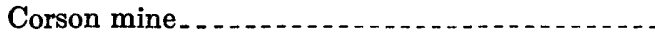

McGall mine

McMullen prospect. .

Vatcher prospect.

Page
1
1
2
3
3
3
10
10
10
13
13
14
16
16
17
18
18

Description of pegmatites-Continued

Raymond district........ 19

General geology $\ldots \ldots \ldots \ldots$

Minor districts ................................ 43

Millard Chandler mine.................. 43

Parker Mountain mine................... 44

Reconnaissance of other areas................ 45

Alton quadrangle............ 45

Gorham quadrangle............ 45

Mount Pawtuckaway quadrangle........... 46

Mount Washington quadrangle............ 47

Plymouth quadrangle...................... 48

Literature cited.

\section{ILLUSTRATIONS}

[Plates are in pocket]

Plate 1. Geologic map and sections of the Palermo No. 1 mine, Groton, Grafton County, N.H.

2. Geologic map and sections of the Beryl Mountain mine, Acworth, Sullivan County, N.H.

3. Geologic map and section of the Chickering mine, Walpole, Cheshire County, N.H.

4. Geologic map of the Corson mine, Nottingham, Rockingham County, N.H.

5. Geologic map of the McGall mine, Raymond, Rockingham County, N.H.

6. Geologic map and section of the Vatcher prospect, Raymond, Rockingham County, N.H.

7. Geologic map and sections of the Chandler mine (pegmatite 7), Raymond, Rockingham County, N.H.

8. Geologic map and section of the Smith No. 1 mine (pegmatites 9 and 10), Raymond, Rockingham County, N.H.

9. Geologic map of pegmatite 37, Raymond, Rockingham County, N.H.

10. Geologic map of the Smith No. 3 prospect (pegmatite 49), Raymond, Rockingham County, N.H.

11. Geologic map of the Blake mine (Mafera mine or pegmatite 56), Raymond, Rockingham County, N.H.

12. Geologic map and sections of the Welch mine (pegmatite 62), Raymond, Rockingham County, N.H.

13. Geologic map of pegmatites $69,70,71,72$, and 73, Raymond, Rockingham County, N.H.

14. Geologic map and section of the Hurley prospect (pegmatites 84, 85, and 86), Raymond, Rockingham County, N.H.

15. Geologic map and section of the Millard Chandler mine, Chatham, Carroll County, N.H.

16. Geologic map and generalized section of the Parker Mountain mine, Strafford, Strafford County, N.H.

Fraure 1. Index map showing locations of principal pegmatites described in this report

2. Sketch map of workings at the Palermo mine, Groton, Grafton County, N.H

3. Geologic map of the Raymond district, Rockingham County, N.H., showing locations of pegmatite exposures studied. 


\section{TABLES}

TABLE 1. Beryl in New Hampshire pegmatites

2. Size of pegmatites, and distribution of minerals therein, Raymond district, N.H.

3. Mineral assemblages in zoned pegmatites of the Raymond district, Rockingham County, N.H 


\title{
BERYL RESOURGES OF NEW HAMPSHIRE
}

\author{
By James J. Page and David M. Larrabete
}

\begin{abstract}
In the course of this study, more than 200 pegmatites were examined either in reconnaissance fashion or in detail, and the most important actual or potential sources of beryl were carefully studied. These included the Palermo No. 1, Beryl Mountain, Blake, Chickering, Smith No. 1, Corson, McGall, Chandler, Millard Chandler, Welch, and Parker Mountain mines, and the Vatcher, Hurley, and Smith No. 3 prospects.

The pegmatites of the Raymond district received special attention, for these previously have received little study and there was a need for knowledge of any beryl resources present. These resources are of no great magnitude, but resources of millinggrade feldspar are of interest. The Palermo No. 1 and Beryl Mountain pegmatites were restudied following development after World War II; these pegmatites are of special interest as both have been known for many years as important sources of beryl.

The relation of beryl to other minerals of the zones, the $\mathrm{BeO}$ content of the beryl, where determined, and the grade of the ore are indicated in the report and in tables 1 to 3 . Some of these data were obtained by the U.S. Geological Survey during World War II, but much new and more detailed information has resulted from this study.

The total estimated resources of beryl in New Hampshire are 1,780 tons, of which about 1,200 tons are probably in crystals at least 1 inch in diameter, and therefore hand-cobbable at 1957 prices. Most of this beryl is so scattered throughout the pegmatites that it represents less than 0.10 percent of the containing rock, and it is recoverable only as a byproduct from feldspar and mica mining activities. Large deposits containing fine-grained, nearly indistinguishable white beryl are unknown in the State, but there has been little if any attempt to search for them. In 1957, any such resources would be classed as "potential ore," but could be of great significance in the future. Search for such ore, and research on beneficiation methods, are recommended.
\end{abstract}

\section{INTRODUCTION}

Beryl occurs sparingly in many pegmatites scattered throughout the southern two-thirds of New Hampshire. The deposits of most economic importance are in the Grafton and Keene districts (fig. 1) in the westcentral and southwestern parts of the State, respectively. The Raymond district (figs. 1 and 3) in the southeastern part of the State may be the third most important, although it has yielded little beryl to 1957 .

Although the pegmatites occur in schists, gneisses, quartz monzonites, and granites, most of the economically important pegmatites are in schist of the Littleton

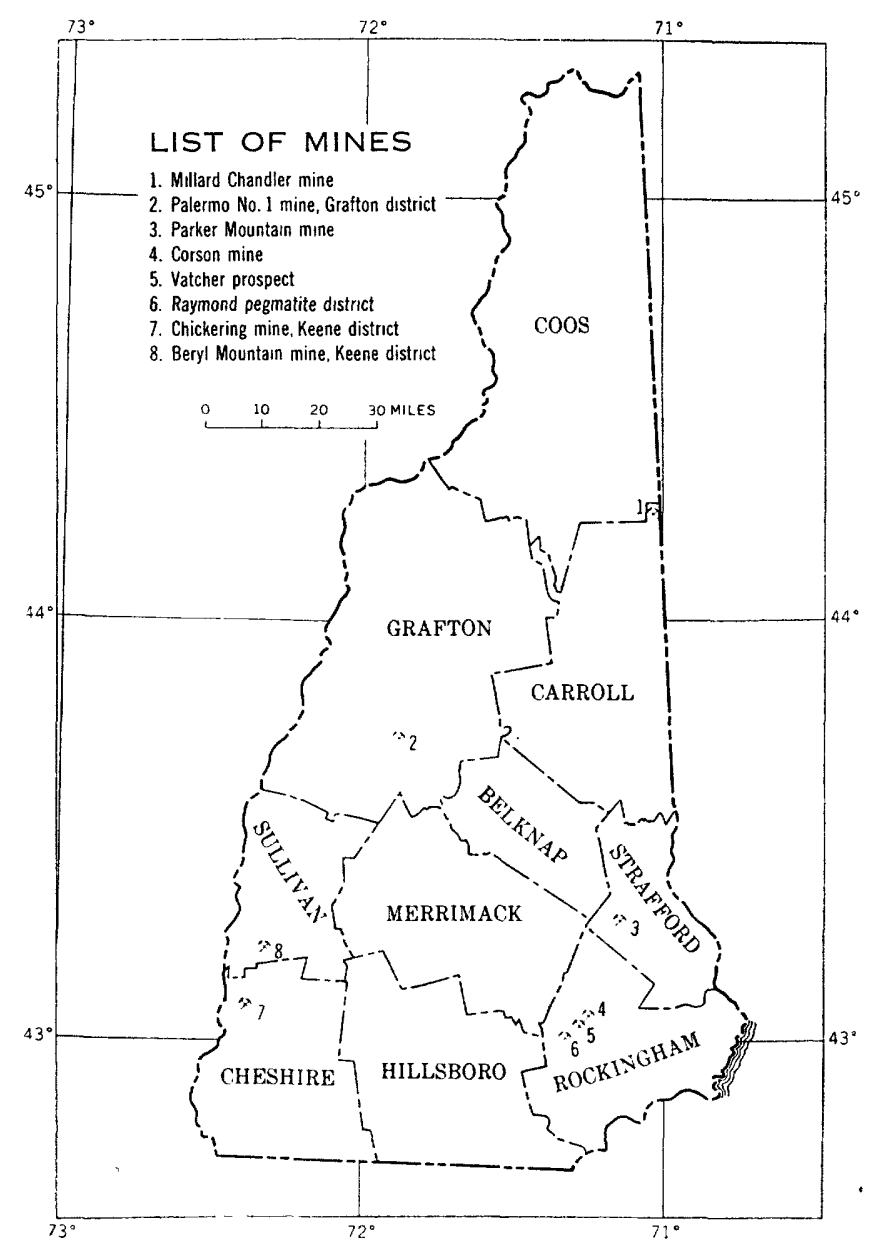

Frgurn 1.-Index map showing locations of principal pegmatites de-

formation of Devonian age. This formation consists chiefly of mica-quartz or quartz-mica schist, in places containing appreciable amounts of sillimanite, actinolite, or andalusite. Some parts are quartzitic, conglomeratic, or include lime-silicate rocks. Relations of the pegmatites to wallrocks and to major structures have been described by Cameron (Cameron and others, 1954, p. 15-19, 22-24).

The pegmatite deposits of New Hampshire have been investigated by members of the U.S. Geological Survey intermittently since 1914. A comprehensive account of the detailed work completed during $1942-45$ is given by. 
Cameron and others (1954), and their report also contains a summary of studies before World War II. Field studies in 1947 led to a report by Olson (1950) on the feldspar in the pegmatites. This phase of the investigations was conducted in behalf of the New Hampshire State Planning and Development Commission.

The purpose of this report is to summarize and bring up to date the information on beryl gained in the pegmatite investigations of $1942-45$, to examine in detail certain beryl-bearing pegmatites discovered in recent years, and to study other pegmatites known or suspected to contain beryl. Fieldwork was started by J. C. Olson and J. W. Adams in 1947, and was continued by J. J. Page in 1948-50. This work was done on behalf of the Division of Raw Materials of the U.S. Atomic Energy Commission and in cooperation with the New Hampshire State Planning and Development Commission. Field assistance in 1948 and 1949 was provided by L. F. Delwig, and in 1949 by P. K. Brown, Jr., and for 1 week by Frederick Stugard, Jr. L. R. Page and D. M. Larrabee briefly restudied the Beryl Mountain mine in 1955. Mapping was done by planetable and telescopic alidade, except where otherwise stated. The descriptions of individual pegmatite deposits (except the Beryl Mountain pegmatites) and tables 2 and 3 were prepared in draft form by J. J. Page. Larrabee revised this draft and tables, wrote the rest of the report, and completed preparation of the maps and tables. The writers are indebted to mine owners and operators for their cooperation and to members of the U.S. Geological Survey who furnished active field assistance and other valuable service.

The two most important beryl-bearing pegmatites are the Palermo No. 1, in Groton, and Beryl Mountain, in Acworth, both of which were mined extensively after World War II. The small area southwest of Raymond village, referred to as the Raymond district, contains 87 pegmatites that were studied in detail. Other pegmatites that have been mined or prospected and mapped in detail are: the Corson mine, Nottingham; the Chickering mine, Walpole; the Millard Chandler mine, Chatham; the Parker Mountain mine, Strafford; and the Vatcher prospect, Raymond. Reconnaissance studies were made elsewhere in the State, notably in the vicinity of Raymond outside the Raymond district, in Strafford, in the general vicinity of Gorham and the Presidential Range of the White Mountains, and east of the productive Grafton district.

\section{BERYL MINING, PRODUCTION, AND USES}

Only rarely in New Hampshire has it been economically feasible to mine a pegmatite over an extended period solely for one mineral, and this probably will be so in the future. The economics of pegmatite mining have been described by Bannerman (1943), and Bannerman and Cameron (1946). During World War II, under subsidy prices for strategic mica and beryl, some deposits were operated profitably for mica, but not for long periods. Mines were operated for mica and for beryl during the Korean emergency, again under Government-sponsored subsidy programs that were continued in 1957.

According to data in the Minerals Yearbooks of the U.S. Bureau of Mines, beryl production in New Hampshire since 1939 was as follows:

\begin{tabular}{|c|c|c|c|}
\hline Year & Tons & Year & \\
\hline 1939 & ${ }^{(1)}$ & 1948 & \\
\hline 1940 & --- & 1949 & \\
\hline 1941 & $-\left({ }^{3}\right)$ & 1950 & \\
\hline 1942 & 16 & 1951 & \\
\hline 1943 & 42 & 1952 & \\
\hline 1944 & $-\left({ }^{1}\right)$ & 1953 & \\
\hline 1945 & 1 & 1954 & \\
\hline 1946 & 5 & 1955 & \\
\hline
\end{tabular}

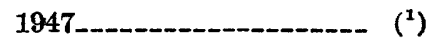

1 Not listed separately. However, production generally was very small.

Beryl has an ideal composition of $\mathrm{Be}_{3} \mathrm{Al}_{2} \mathrm{Si}_{6} \mathrm{O}_{18}$. This formula indicates a content of 14.0 percent $\mathrm{BeO}$ or 5 percent $\mathrm{Be}$ (Fleischer and Cameron, 1946). Commercial beryl concentrates have a lower $\mathrm{BeO}$ content partly because other elements substitute for $\mathrm{Be}$ in the mineral structure and also because the concentrates contain other minerals. These minerals may be small inclusions or alteration products in the beryl. More commonly, however, the contaminants are minerals from the matrix surrounding the beryl, chiefly quartz, feldspar, and mica. Many beryl crystals are euhedral, and where surrounded by quartz they break clean on crystal faces; thus a clean product can be produced by hand-cobbing. Other beryl crystals are intergrown with the minerals of the matrix, especially feldspar, and the cobbed concentrate is therefore impure.

Mining has been by small-scale methods, mostly in open pits from which the beryl was concentrated by hand-cobbing. Recently some beryl has been sold to the General Services Administration and some to private companies. In 1957 the Government paid a flat rate of $\$ 0.20$ per pound or $\$ 400$ per ton for beryl accepted on visual inspection. The price of analyzed beryl is based on the content of $\mathrm{BeO}$. Beryl containing 8.0 to 8.9 percent $\mathrm{BeO}$ is bought at $\$ 40$ per unit, 9.0 to 9.9 percent $\mathrm{BeO}$ at $\$ 45$ per unit, 10.0 to 11.9 percent $\mathrm{BeO}$ at $\$ 50$ per unit, and 12 percent or more at $\$ 55$ per unit. As an example, beryl having 12 percent $\mathrm{BeO}$ is worth $\$ 660$ per ton. For comparison, in the late 1920 's and early 1930's, beryl sold for $\$ 35$ per ton.

Beryl is the only known economic source of beryllium, 
which has been used primarily in beryllium-copper alloys for special types of springs and bushings; it has many other uses. New applications of beryllium of great importance are in the atomic-energy field as a moderator and reflector of neutrons. The uses and technology of beryllium have been discussed by Reno (1956) in "Mineral Facts and Problems," published by the U.S. Bureau of Mines. A more complete compendium on beryllium is contained in "Materials Survey, Beryllium," compiled by the U.S. Bureau of Mines (1953) with the cooperation of the U.S. Geological Survey in behalf of the National Security Resources Board.

\section{INTERNAL STRUCTURE AND MINERALOGY OF PEGMATITES}

The internal structure and mineralogy of granitic pegmatites have been described many times in recent years (Bannerman, 1943; Cameron and others, 1949, 1954; Jahns, 1955; Page and others, 1953), and the details are outlined only briefly here.

Pegmatites that can be mined economically ordinarily show some degree of systematic arrangement of the constituent minerals into two or more lithologic units or zones, and the mineral to be extracted is more abundant in some units than in others. Boundaries between units are marked by changes in mineralogy, proportions of minerals, or texture. In many pegmatites these boundaries are gradational, in others they are sharp and easily distinguished. The names of the units are formed by hyphenating the names of the chief mineral constituents, the names of the minerals appearing in order of abundance.

Zones are defined as continuous or discontinuous shells or units that in many pegmatites have the same shape as the entire body. Zones are classified as follows, in order from the outside; border zone, wall zone, intermediate zones, and core.

Border zones are commonly less than 6 inches thick, and are made up chiefly of quartz, muscovite, and plagioclase. Wall zones are much thicker; they also consist of quartz, muscovite, and plagioclase, but some contain perthite. Intermediate zones have more perthite and less plagioclase than outer units. The cores are commonly quartz and perthite, or quartz alone.

Fracture fillings are commonly tabular bodies that fill fractures in previously consolidated pegmatite. Replacement bodies are formed along boundaries between pegmatite units, along fractures, at the contact of pegmatite and wallrock, or along other structural features within the pegmatite. Many replacement bodies are controlled by fractures.

In a general way, grain sizes referred to in the text may be described as follows:
Fine Less than 1 inch Medium 1 to 4 inches
Coarse 4 to 12 inches
Very coarse Greater than 12 inches

\section{METHODS USED IN ESTIMATING RESOURCES}

To eliminate the confusion arising from the common use of the terms "reserves" and "resources" interchangeably in past work, the definitions of Blondel and Lasky (1956) are used in this report. Reserves refer to minerals exploitable under present economic and technologic conditions; potential ores are those awaiting more favorable conditions; resources are the sum of the reserves and potential ores.

The percentage of beryl in a pegmatite may be determined by several methods: (a) by measuring the area of all beryl crystals on representative exposures of each unit; (b) measuring the length of crystals along equally spaced traverses, as in the Rosiwal petrographic method; (c) measurement of crystals intersected in core drilling; or (d) by analyses of representative samples of the beryl-bearing pegmatite. Visual estimates, although used at times, are much less accurate and commonly misleading. The tendency is to greatly over estimate the amount of beryl present.

The volume of the beryl-bearing unit is determined by projection along strike, dip, and plunge. Where more than one structural interpretation of the berylbearing unit can be made on the basis of available data, it is necessary to acquire more information by field exploration. The determination of grade and reserves of pegmatite minerals is treated by Norton and Page (1956).

The $\mathrm{BeO}$ content of the beryl is determined by measuring the omega index of refraction of the crystal, as this index varies with the $\mathrm{BeO}$ content. This method was developed by W. T. Schaller and R. E. Stevens (Norton and others, 1958).

\section{BERYL RESOURCES}

The resources of beryl in known pegmatites of New Hampshire may be 1,634 tons in the indicated and inferred category. In the Raymond district an additional 146 tons of potential ore may be present, making a total of 1,780 tons. Of this quantity about 1,200 tons are in crystals at least 1 inch in diameter and therefore recoverable by hand-cobbing. Most of the beryl in New Hampshire is so scattered throughout any given zone or zones in a pegmatite that it can be recovered only as a byproduct from mining for other minerals, such as feldspar or mica. The beryl content of the different zones ranges from a trace to an average of 9.6 percent in one pegmatite, but in most it is less than 0.10 percent. Only a very minute part of the beryl listed in table 1 is suitable for gems. 
TABLE 1.-Beryl in

[Many data are from Cameron and others (1954)]whose fieldwork was done in 1942-45;

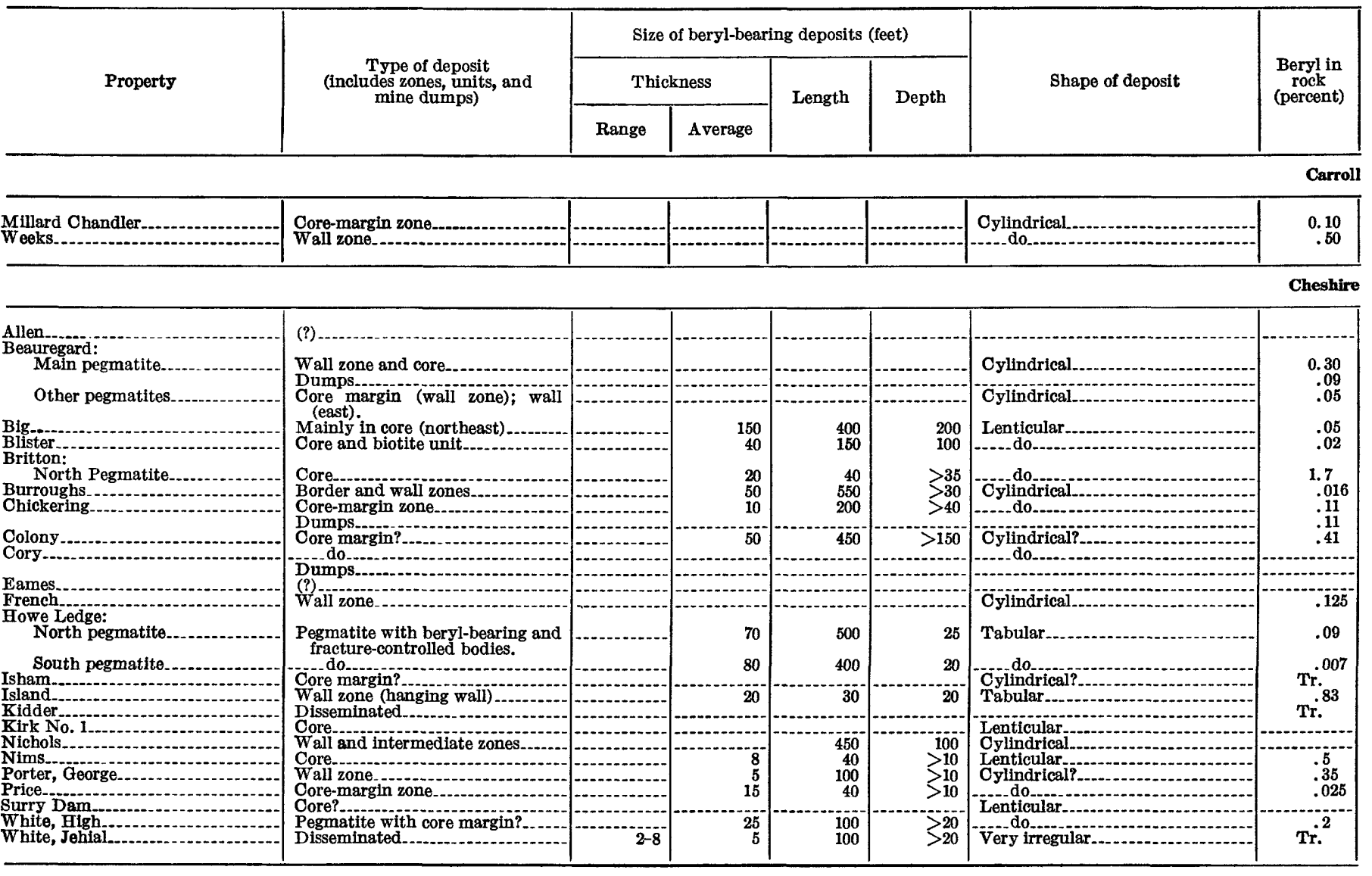

See footnotes at end of table. 
New Hampshire pegmatites

the rest are from fieldwork done in 1948-50, except for that on Beryl Mountain, done in 1955]

\begin{tabular}{|c|c|c|c|c|c|}
\hline \multirow[b]{2}{*}{ Basis } & \multicolumn{2}{|c|}{ Size of crystals } & \multirow{2}{*}{$\begin{array}{c}\text { Percent } 1 \\
\text { hand- } \\
\text { cobbable } \\
\text { beryl }\end{array}$} & \multirow{2}{*}{$\begin{array}{c}\text { Percent } \\
\text { BeO in } \\
\text { beryl }\end{array}$} & \multirow{2}{*}{$\begin{array}{l}\text { Associated industrial minerals } \\
\text { (not in order of abundance) }\end{array}$} \\
\hline & $\begin{array}{l}\text { A verage } \\
\text { (square } \\
\text { inches) }\end{array}$ & $\underset{\text { (inches) }}{\text { Maximum }}$ & & & \\
\hline
\end{tabular}

\section{County}

\begin{tabular}{|l|r|r|r|r|r|r}
\hline $\begin{array}{l}\text { Mineral measurements. } \\
\text { Production data }\end{array}$ & 7.37 & 80 & $13.5-13.7$ & $\begin{array}{l}\text { Potassic and sodic feldspar, scrap mica. } \\
\text { Potassic and sodic feldspar, scrap mica, columbite. }\end{array}$ \\
\hline
\end{tabular}

County

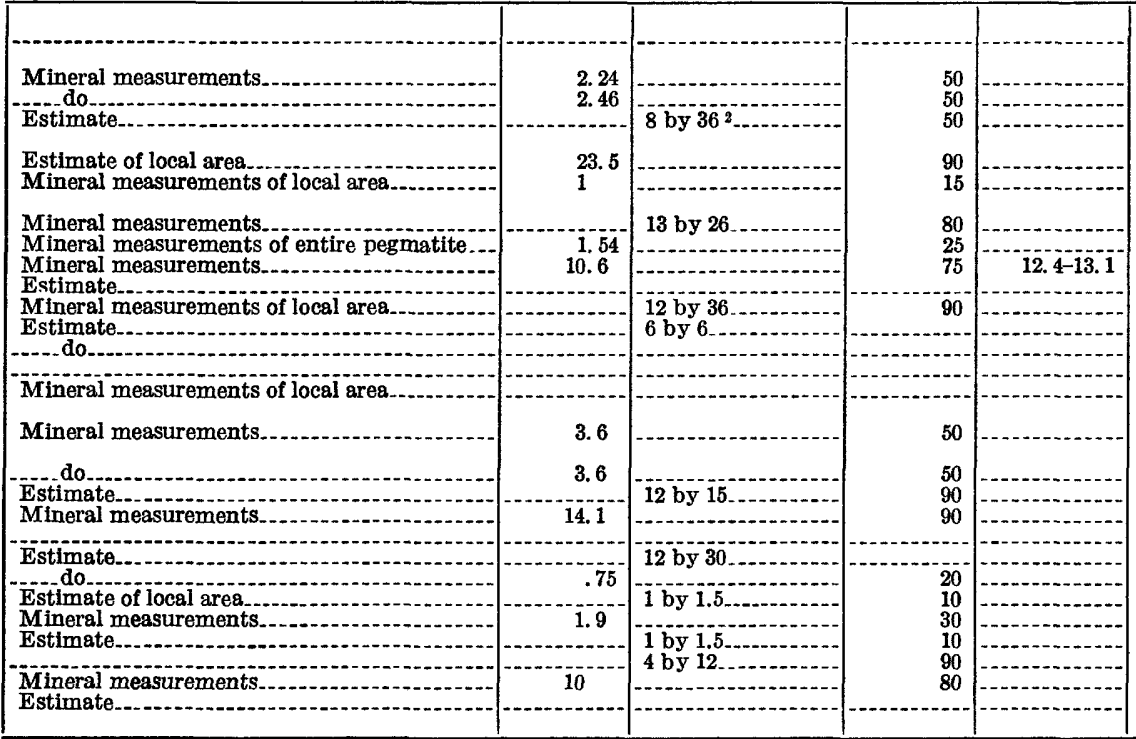

Potassic and sodic feldspar, scrap mica.

Potassic and sodic feldspar, scrap and sheet mica.

Do.

Potassic and sodic feldspar, scrap mica.

Do.

Lithium minerals (minor)

Potassic and sodic feldspar, scrap mica.

Potassic and sodic feldspar, scrap and sheet mica.

Potassic and sodic feldspar, scrap mica.

Potassic and sodic feldspar, scrap and sheet mica.

Potassic and sodic feldspar, scrap mica.

Potassic and sodic feldspar, scrap and sheet mica.

Sodic feldspar, scrap and sheet mica.

Potassic and sodic feldsdar, scrap and sheet mica.

Do.

Potassic and sodic feldspar, scrap mica.

Sodic feldspar, scrap and sheet mica, tantalite reported.

Potassic and sodic feldspar, scrap and meet mica.

Sodic feldspar, scrap and meet mica.

Potassic and sodic feldspar, scrap mic

Potassic and sodic feldspar, scrap and sheet mica. 
TABLE 1.-Beryl in

[Many data are from Cameron and others (1954) whose feldwork was done in 1942-45;

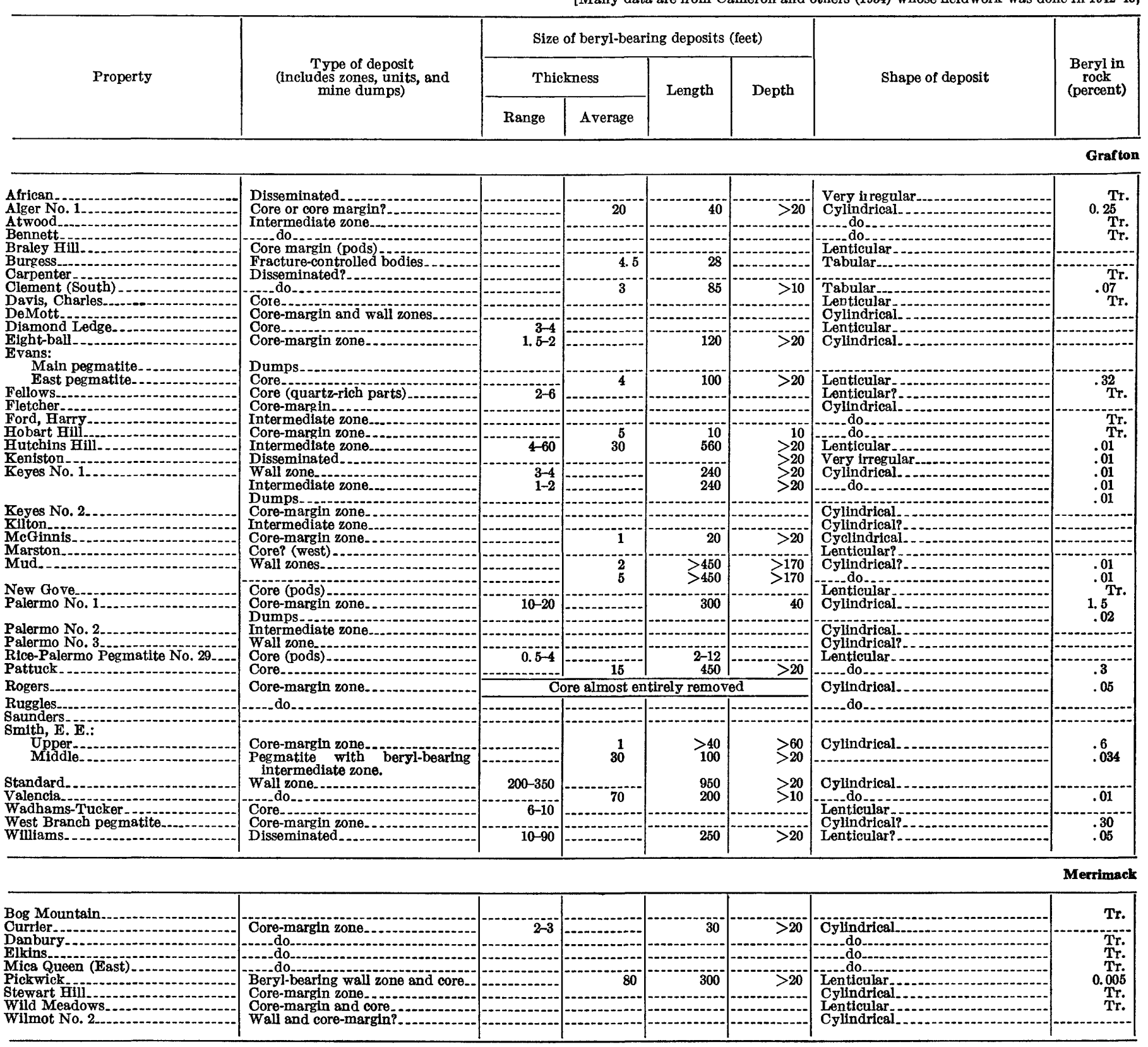

See footnotes at end of table. 
New Hampshire pegmatites-Continued

the rest are from fieldwork done in 1948-50, except for that on Beryl Mountain, done in 1955]

\begin{tabular}{|l|c|c|c|c|c|}
\hline \multirow{2}{*}{ Basis } & \multicolumn{2}{|c|}{ Size of crystals } & $\begin{array}{c}\text { Percent 1 } \\
\text { hand- } \\
\text { cobbable } \\
\text { beryl }\end{array}$ & $\begin{array}{c}\text { Percent } \\
\text { BeO in } \\
\text { beryl }\end{array}$ & $\begin{array}{c}\text { Associated industrial minerals } \\
\text { (not in order of abundance) }\end{array}$ \\
\cline { 1 - 5 } & $\begin{array}{c}\text { Average } \\
\text { (square } \\
\text { inches) }\end{array}$ & $\begin{array}{c}\text { Maximum } \\
\text { (inches) }\end{array}$ & \\
\hline
\end{tabular}

\section{County}

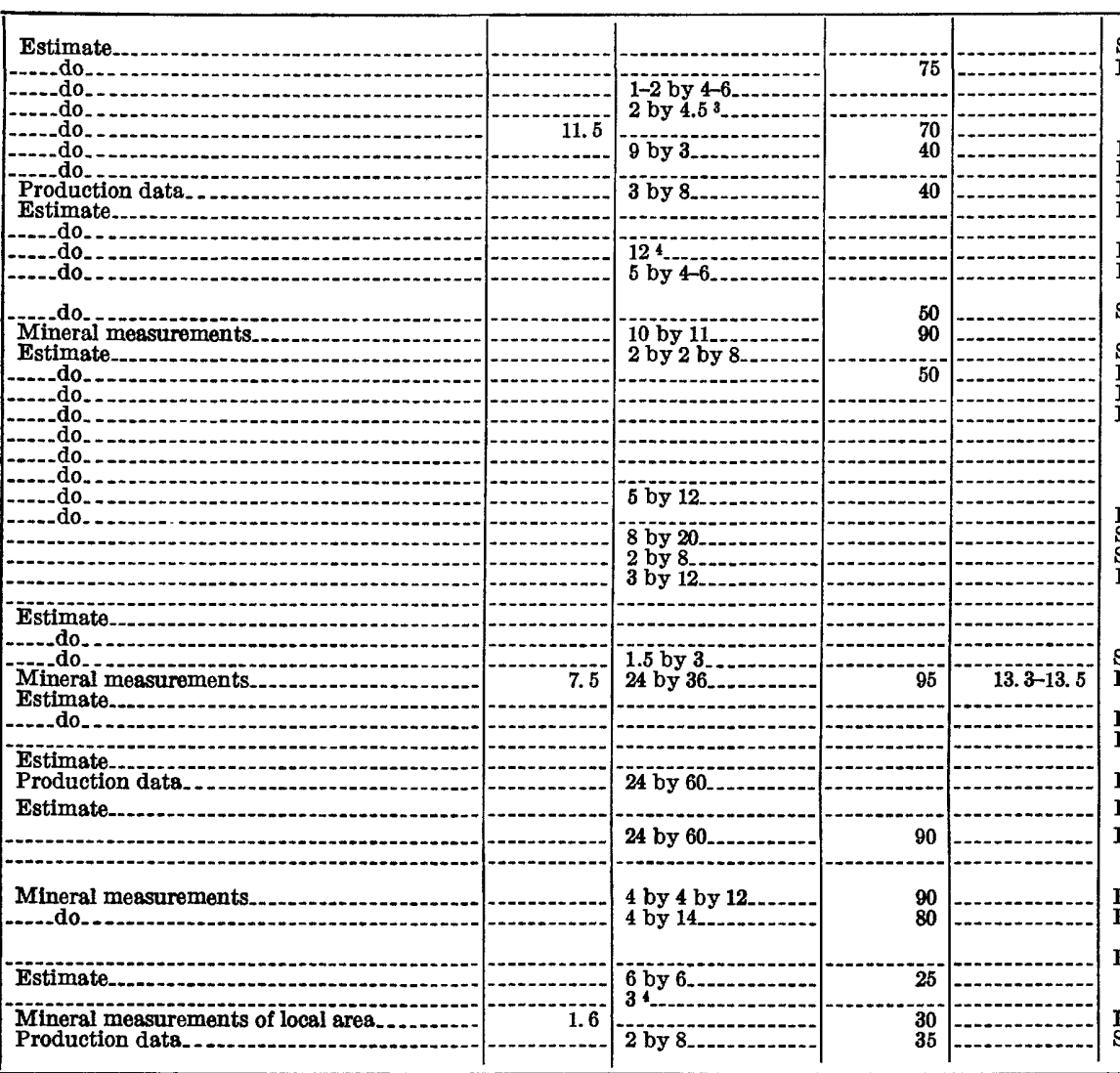

Scrap and sheet mica.

Potassic and sodic feldspar, scrap and sheet mica.

Do.

Do.

Potassic and sodic feldspar, scrap mica.

Potassic and sodic feldspar, scrap and sheet mica.

Potassic feldspar scrap and sheet mice

Potassic and sodic feldspar, scrap and sheet mica.

Do.
Dassic

Potassic and sodic feldspar, scrap and sheet mica.

Sodic feldspar, scrap mica.

Do.
Sodic feldspar, scrap and sheet mica.

Potassic and sodic feldspar, scrap and sheet mica. Potassic and sodic feldspar, scrap mica, spodumene (minor). Potassic and sodic feldspar, scrap and sheet mica.

Do.

Do.

Potassic and sodic feldspar, scrap mica.

Sodic feldspar, scrap mica.

Potassic and sodic feldspar, scrap and sheet mica.

Do.

Do.

Scrap mica.

Potassic and sodic feldspar, scrap and sheet mica, phosphates.

Potassic feldspar, scrap and sheet mica.

Potassic and sodic feldspar, scrap and sheet mica.

Do.
Potassic and sodic feldspar, sheet and scrap mica, columbite.

Potassic and sodic feldspar, scrap mica.

Potassic and sodic feldspar, sheet and scrap mica. Do.

Potassic and sodic feldspar, scrap and sheet mica, columbite. Potassic and sodic feldspar, scrap mica.

Potassic and sodic feldspar, scrap and sheet mica.

Do.

Potassic and sodic feldspar, scrap mica.

Sodic feldspar, scrap and sheet mica.

\section{County}

\begin{tabular}{|c|c|}
\hline Estimate............ & \\
\hline $\begin{array}{l}\text { Estimate do } \\
\text { Mineral measurements } \\
\text { Estimate_do }\end{array}$ & 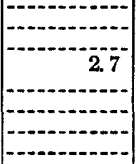 \\
\hline
\end{tabular}

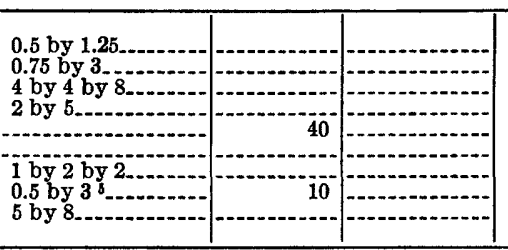

Scrap mica.

Potassic and sodic feldspar, scrap mica Potassic and sodic feldspar, scrap and sheet mica. Do. Do.

Potassic and sodic feldspar, scrap mica.

Potassic and sodic feldspar, scrap and sheet mica. 
TABLE 1.-Beryl in

[Many data are from Cameron and others (1954) whose fieldwork was done in 1942-45;

\begin{tabular}{|c|c|c|c|c|c|c|c|}
\hline \multirow[b]{2}{*}{ Property } & \multirow{2}{*}{$\begin{array}{l}\text { Type of deposit } \\
\text { (includes zones, units, and } \\
\text { mine dumps) }\end{array}$} & \multicolumn{4}{|c|}{ Size of beryl-bearing deposits (feet) } & \multirow[b]{2}{*}{ Shape of deposit } & \multirow{2}{*}{$\begin{array}{c}\text { Beryl in } \\
\text { rock } \\
\text { (percent) }\end{array}$} \\
\hline & & \multicolumn{2}{|c|}{ Thlckness } & Length & Depth & & \\
\hline
\end{tabular}

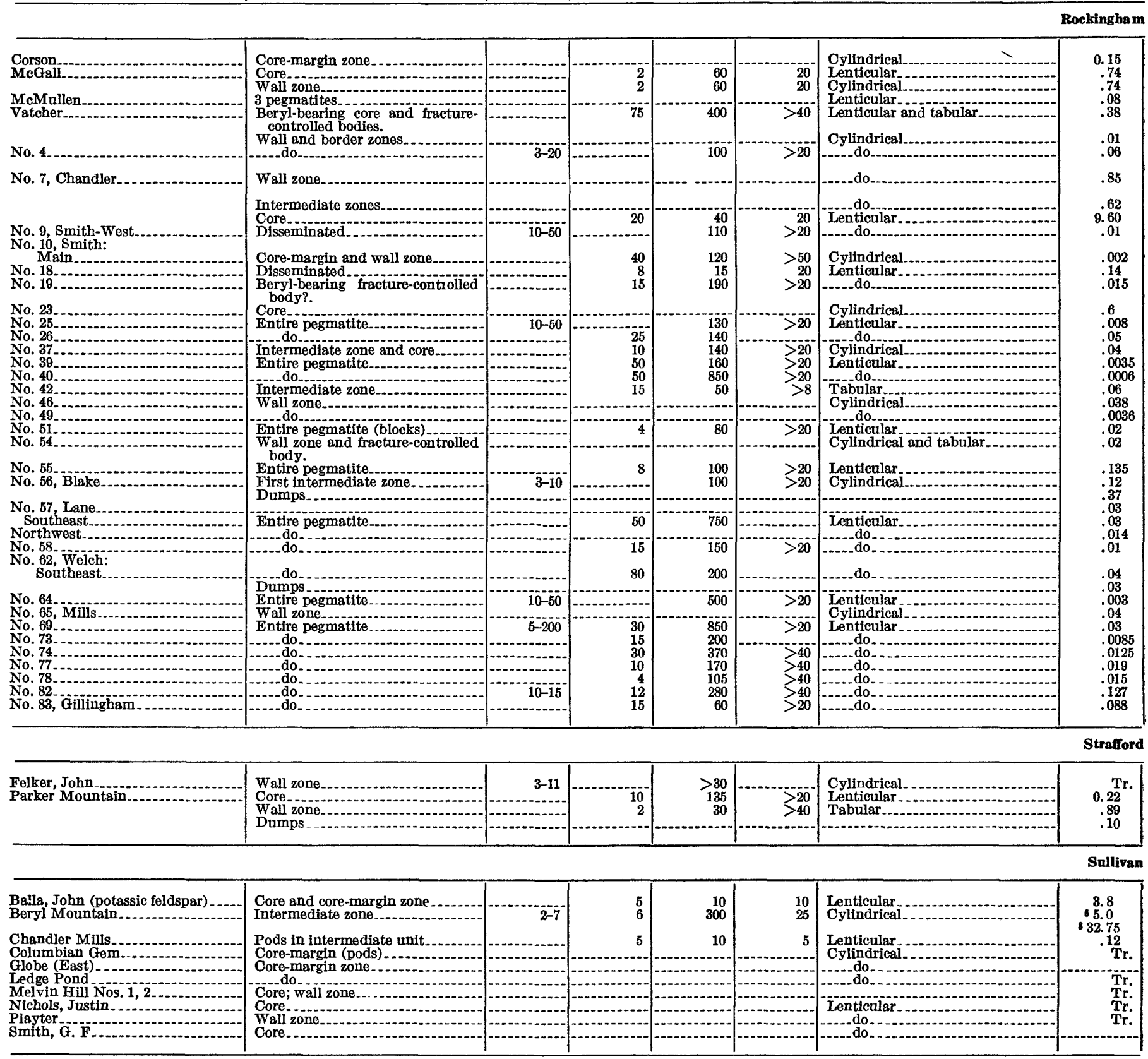

\footnotetext{
3 One crystal.

3 One crysta
In length.

In lengt.

- Av corage.

Approximately.

- Maximum average.
}

1 Crystals larger than 1 inch in diameter. 
New Hampshire pegmatites-Continued

the rest are from fieldwork done in 1948-50, except for that on Beryl Mountain, done in 1955]

\begin{tabular}{|c|c|c|c|c|c|}
\hline \multirow[b]{2}{*}{ Basis } & \multicolumn{2}{|c|}{ Size of crystals } & \multirow{2}{*}{$\begin{array}{l}\text { Percent } 1 \\
\text { hand- } \\
\text { cobbable } \\
\text { beryl }\end{array}$} & \multirow[b]{2}{*}{$\begin{array}{c}\text { Percent } \\
\text { BeO in } \\
\text { beryl }\end{array}$} & \multirow{2}{*}{$\begin{array}{l}\text { Associated industrial minerals } \\
\text { (not in order of abundance) }\end{array}$} \\
\hline & $\begin{array}{l}\text { A verage } \\
\text { (square } \\
\text { inches) }\end{array}$ & $\underset{\text { (inches) }}{\text { Maximum }}$ & & & \\
\hline
\end{tabular}

\section{County}

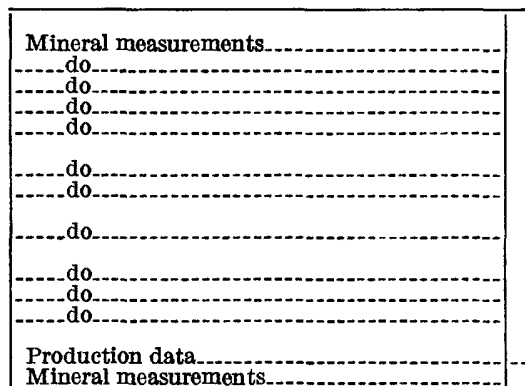

Mineral measurements.

[-do do

- do do

- do

-

Mineral measurements of entire pegmatite..

Mineral measurements........

Production data.

Mineral measurements......

-..-do.-

-

-.-do do

-

-

-.--do do.

-

Production data

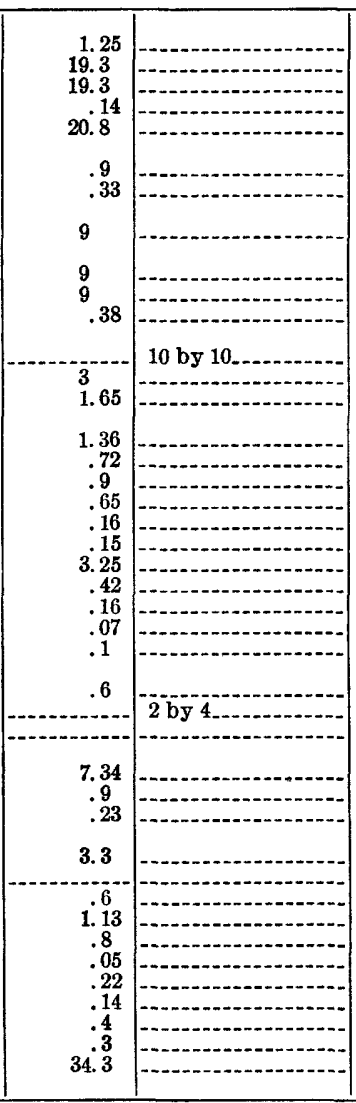

Potassic and sodic feldspar, scrap mica.

Potassic and sodic feldspar, scrap mica, spodumene, columbite

otassic and sodic feldspar, scrap mica,

Potassic and sodic feldspar, scrap mica, columbite.

Potassic feldspar, scrap mica.

13.0

Potassic and sodic feldspa
lepidolite, phosphates.

$12.5-12.6$

Potassic and sodic feldspar, scrap mica, columbite.

Potassic and sodic feldspar, scrap mica.

Potassic feldspar.

13. 1 Potassic feldspar, scrap mica.

0 Scrap and sheet mica, columbite.

13. 0-13. 1 Potassic feldspar, scrap mica, columbite.

Potassic feldspar, scrap mica, columbite.

Potassic feldspar, scrap mica.

12. 8-13.2
Do.

12. 9-13.1 Potassic feldspar, scrap and sheet mica.

Potassic feldspar, scrap and shee
Potassic feldspar, scrap mica.

Potassic
Do.

13.1-13. 2 Potassic feldspar, scrap mica.

13.0 Do.

Potassic feldspar, scrap and sheet mica, columbite.

Potassic feldspar, serap mica.

12. 8-13.2 Do.

Potassic feldspar, scrap mica, columbite.

Potassic feldspar, scrap mics.

12. $9-13.0$

Do.

Do.

Potassic feldspar.

Potassic feldspar, scrap mica, columbite.

Potassic feldspar, scrap mica,
Potassic feldspar, scrap mica.

\section{County}

\section{Estimate}

Mineral measurements.-

Estimate

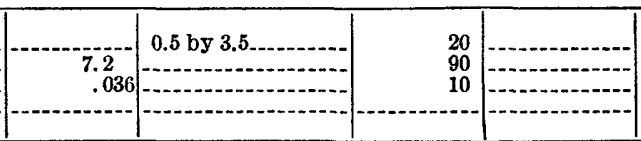

Scrap and sheet mica.

Scrap and sheet mica.
Potassic and sodic feldspar, scrap and sheet mica, columbite.

\section{County}

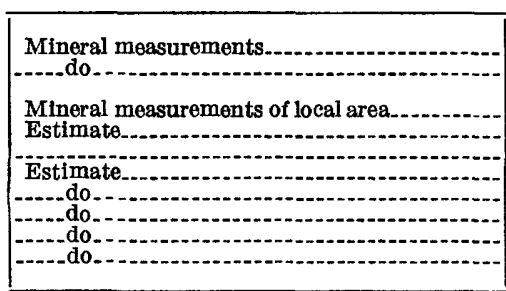

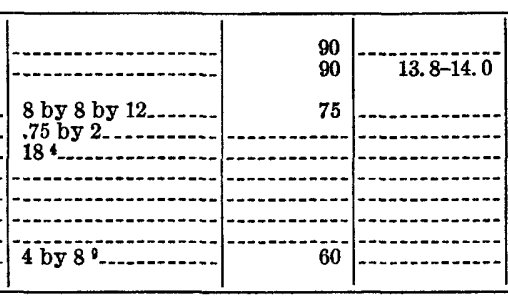

Potassic and sodic feldspar, scrap mica.

Potassic and sodic feldspar, scrap mica, quartz.

Potassic and sodic feldspar, scrap and sheet mica.

Do.

Do.

Do.
Potassic and sodic feldspar, scrap mica.

Sodic feldspar, scrap and sheet mica. 
Some pegmatites may contain additional beryl that has not been recognized in the field because it is extremely fine grained and white. During World War II, such beryl was not looked for, generally, as it was not recoverable. Such beryl can be recovered only by milling, and suitable methods have not yet been developed. Although the estimated tonnage of hand-cobbable beryl in New Hampshire is small there are few areas in the United States that contain more. If a domestic supply of beryllium is urgently needed, more sound research in milling and beneficiation of finegrained beryl is needed.

\section{DESCRIPTION OF PEGMATITES}

\section{GRAFTON DISTRICT}

PALERMO NO. 1 MINE

Although many pegmatites have been mined in the Grafton district, the Palermo No. 1 mine not only has been the sole significant source of beryl but also has yielded the largest production of beryl in New Hampshire during World War II. Production since 1945 has greatly exceeded that of former years as a result of much higher selling prices. This mine (pl. 1) is 1 mile S. $61^{\circ} \mathrm{W}$. of the village of North Groton, Grafton County, and about 2 miles by State, town, and mineaccess roads from that village. The Palermo mine is one of the best known localities for collecting pegmatite minerals in New Hampshire (Sterrett, 1915, 1923; Berman, 1927; Verrow, 1940, 1941; Frondel, 1941; Frondel and Lindberg, 1948).

The mine was opened for sheet mica in 1863 and most of the underground work was done before 1900 . In 1914, the mine was purchased by the General Electric Co., Schenectady, N.Y. In 1914-15, General Electric operated the mine for mica, mostly above the level of the lower opencut, and sometime after 1920 the small opencuts on top of the outcrop were made for feldspar. In 1942-43 this company again mined for mica and beryl near the top of the pegmatite, but some of their mica production during this period was from the dumps. Following these operations, H. A. Ashley (later as the Ashley Mining Corp.) mined mica, feldspar, scrap mica, and beryl until late 1949.

Sterrett (1923, p. 131-132) visited the mine in October 1914, and described the underground workings shown in figure 2 in the following fashion (numbers refer to features shown on fig. 2):

At the (north) end of the lower, or southern, open cut [1] there is a large tunnel or room [2] 50 feet long with deep inclined stopes [7] extending from it to the northeast and east and a drift with stopes extending upward to the north; an upraise [3] connects with workings from the outcrop about 50 feet higher and to the west, where an open cut [4] 30 feet long

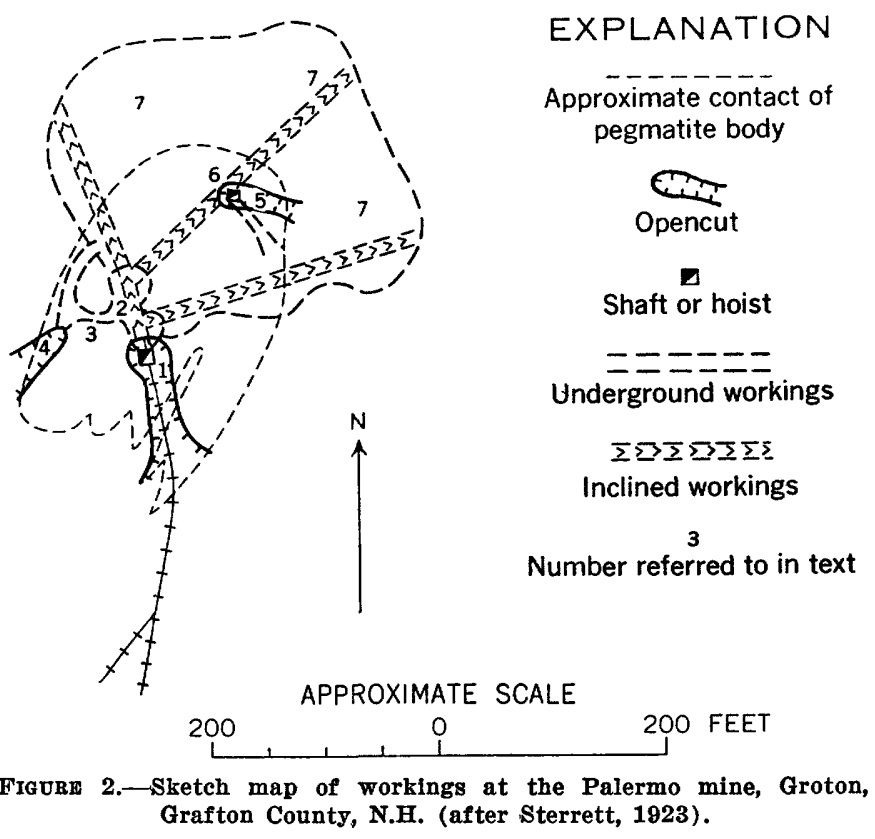

had been made with drifts and stopes carried underground from it. Another open cut [5] 40 feet long and 35 feet deep had been made northeast of the main lower open cut and about 40 feet higher. From this open cut [5] an inclined shaft [6] was sunk that connected with the main stopes [7] at a depth of 4 feet below the bottom of the main open cut [1].

In $1948-49$ the accessible workings consisted of the lower open cut (1), that part of the tunnel or room (2) still accessible above water level, the raise (3), the opencut (4) and some of the drifts and stopes from it, and possibly part of the opencut (5) and inclined shaft (6). The large stopes (7) are filled with water. Small opencuts were made on top of the outcrop north of the older workings before 1944, and by November 1949 an opencut 140 feet long, 110 feet wide, and 40 feet deep had been developed.

The mine has been mapped and studied by the following members of the U.S. Geological Survey from 1944 to 1949 : J. B. Hadley, F. H. Main, and A. H. McNair in 1944-45 (Cameron and others, 1954, p. 215217) ; J. C. Olson and J. W. Adams in 1947 (Olson, 1950) ; and J. J. Page, L. F. Dellwig, Frederick Stugard, Jr., and P. K. Brown, Jr. in 1948-49 (pl. 1).

The pegmatite is roughly tadpole shaped with a blunt northeast end that thins rapidly south of the main opencut (pl. 1). It is at least 280 feet long and as much as 140 feet wide. The average strike seems to be nearly $\mathrm{N}$. $45^{\circ} \mathrm{E}$. and the dip is variable to the southeast. The hanging wall dips from $40^{\circ} \mathrm{SE}$. to vertical. The footwall dips steeply southeast near the surface, flattens slightly a short distance below the surface, and apparently steepens again to include the older water-filled stopes reached from the old lower opencut. The aver- 
age dip of the footwall is about $50^{\circ} \mathrm{SE}$. The pegmatite appears to plunge $20^{\circ}$ northeastward under the overlying schist. It is mostly concordant with the wallrock which is quartz-mica-sillimanite schist. Sillimanite needles and larger crystals as much as one-half by 2 inches are commonly altered to sericite. The wallrock on the footwall side of the pegmatite south of the opencut has been injected by pegmatitic material.

There are six pegmatite units at the Palermo mine: a quartz-muscovite-plagioclase border zone; a plagioclase-quartz-muscovite wall zone containing sheet mica; a plagioclase-quartz-perthite intermediate zone containing sheet mica ; a quartz-plagioclase-perthite intermediate zone; plagioclase-quartz-muscovite-perthite intermediate (core-margin) zone containing beryl, phosphates, and uranium minerals; and a quartz-perthite core. Five of these are shown on plate 1; the border zone is too thin to be shown at the scale used.

The border zone is very fine grained quartzmuscovite-plagioclase pegmatite. It is exposed at the north and east (hanging-wall) contacts of the pegmatite and schist, and is ordinarily less than 4 inches thick. At the footwall contact, the schist has been injected by pegmatitic material, and the contact between wallrock and the wall zone of the pegmatite is too gradational to permit separation of a border-zone unit. The unit consist of 40-50 percent quartz, 30-40 percent muscovite, and 10-20 percent plagioclase $\left(\mathrm{An}_{12}\right)$. Biotite, probably from the wallrock, is a minor accessory mineral.

The medium-grained plagioclase-quartz-muscovite wall zone was the source of most of the sheet mica produced at the Palermo mine. This unit is most continuous and probably thickest near the north and east contacts of the pegmatite, where it is exposed along the hanging wall. Where exposed, the unit does not exceed 5 feet in thickness. It seems to be the unit mined in the old underground workings described by Sterrett (1923, p. 131-132). The average composition of the unit is 50 percent plagioclase $\left(\mathrm{An}_{4-7}\right), 35$ percent quartz, and 15 percent muscovite. Biotite and black tourmaline are minor accessory minerals.

The first intermediate zone is medium- to coarsegrained plagioclase-quartz-perthite pegmatite containing sheet muscovite. This zone is exposed in and near the old workings at the south and southwest sides of the pegmatite. It is as much as 25 feet thick and part of it was the unit mined for sheet mica in these workings. This unit, and the second intermediate zone, exposed in and around the main opencut to the north, are so similar in position, texture, and location in relation to the other units that they could be considered the same unit, but they are sufficiently different in composition to show them on the map as separate units. The average composition is 45 percent plagioclase $\left(\mathrm{An}_{4-7}\right), 25$ percent quartz, 25 percent perthite, and 5 percent muscovite. The proportions of these minerals vary greatly in the zone. Black tourmaline and biotite are the most common accessory minerals, biotite commonly occurring in strips intergrown with muscovite. Other minerals are apatite, lazulite, pyrite, and chalcopyrite.

The second intermediate zone is medium- to coarsegrained quartz-plagioclase-perthite pegmatite. It is as much as 40 feet thick on the east side of the pegmatite but thins at depth on the west side. The unit is absent in some of the accessible underground workings. Its shape suggests that it may have originally formed a hood over the top of the pegmatite that extended farther downdip on the hanging-wall side than on the footwall. The average composition is 35 percent quartz, 35 percent plagioclase $\left(\mathrm{An}_{4-7}\right)$, and 30 percent perthite. This zone is variable in composition, and any 1 of the 3 major constituents locally may comprise as much as 75 percent of the unit. Perthite was mined from this unit before 1942.

The third intermediate (core-margin) zone is fine- to coarse-grained pegmatite consisting of plagioclase, quartz, muscovite, and perthite, with accessory beryl and phosphate minerals. This unit is thickest, possibly 30 feet thick, on the footwall side of the core; only discontinuous lenses of the unit are found on the hanging-wall side. Mapping in 1944 (Cameron and others, 1954) showed a small exposure of beryl-bearing pegmatite on top of the outcrop near the present center of the opencut, suggesting that the core-margin zone completely surrounded the core.

The composition of the unit is variable; the average is 30 percent plagioclase $\left(A n_{2-4}\right), 25$ percent quartz, 25 percent muscovite, and 20 percent perthite. The plagioclase is cleavelandite that occurs in oval aggregates as much as 10 feet long and 5 feet wide bordered by rims of greenish-yellow muscovite. Equally large aggregates of medium-grained muscovite and quartz separate the cleavelandite aggregates. Quartz is commonly massive and similar to that of the core. Large crystals of beryl are most abundant near the inner edge of the unit adjacent to massive quartz of the core, but smaller crystals are found in the muscovite aggregates. Lenses of phosphate-rich minerals are present near the core. Uranium minerals are in the muscovite masses.

This unit contains most of the rare minerals reported at the Palermo mine. A list of some of the minerals found at the mine by Frondel (1941, p. 145), Verrow (1941, p. 208-211), and Frondel and Lindberg (1948, p. 135-141) is given below : 


$\begin{array}{ll}\text { Amblygonite } & \text { Ludlamite } \\ \text { Apatite } & \text { Manganite } \\ \text { Autunite } & \text { Melanterite } \\ \text { Brazilianite } & \text { Messelite(?) } \\ \text { Cyrtolite } & \text { Psilomelane } \\ \text { Dufrenite } & \text { Pyrite } \\ \text { Eosphorite-childrenite } & \text { Rhodochrosite } \\ \text { Fairfieldite } & \text { Siderite } \\ \text { Ferri-sicklerite } & \text { Triphylite } \\ \text { Graftonite } & \text { Triploidite } \\ \text { Gummite } & \text { Uranophane } \\ \text { Heterosite } & \text { Vivianite } \\ \text { Lazulite } & \text { Whitlockite } \\ \text { Limonite } & \text { Zeolite } \\ \text { Lollingite } & \end{array}$

The core-margin zone includes the minerals and features attributed to replacement bodies in and adjacent to the core during earlier studies of the Palermo pegmatite (Cameron and others, 1954). During the 1948-49 investigations, further study of the relation of this unit to the adjacent units indicated that it could be described best as a true zone and that the replacement features could be explained without requiring a separate replacement body of later age. The best evidence of the zonal characteristics of this unit is its spatial relation to other units of the pegmatite. It has a definite and predictable location in the sequence of units, and although it is discontinuous on the hangingwall side of the core, so also are many zones, whereas replacement units commonly show crosscutting relation to surrounding units. Similar units have been mapped as zones in other pegmatites such as the Hyatt Beryl pegmatite, Larimer County, Colo., and the Bob Ingersol Dike No. 2 pegmatite, Keystone, S. Dak. (Page, 1950, p. 28). Replacement textures, such as those produced by the corrosion of earlier formed crystals, have been used to indicate that this unit was a "replacement body," but these textures are as easily explained by the action of the residual pegmatite liquid on earlier formed crystals during the normal sequence of pegmatite crystallization.

The core consists of very coarse grained quartzperthite pegmatite occurring in the thickest part of the body. Massive quartz (60 percent) surrounds large subhedra of perthite ( 40 percent); some perthite crystals are as much as 30 feet long and 10 to 15 feet in cross section. Plagioclase is a minor accessory mineral, commonly occurring as thin rims of sugary-textured albite $\left(\mathrm{An}_{4}\right)$ between perthite and quartz.

The Palermo pegmatite has yielded large quantities of sheet and scrap mica, potassic feldspar, and beryl. Reserves of these minerals are unknown, but probably are much less than the past production. Large parts of the core and core-margin zones have been mined out, and the great extent of underground workings indicate that sheet-mica-bearing units have been largely removed.

Beryl is concentrated near the inner edge of the coremargin zone. The discontinuous lenses of this zone on the hanging-wall side of the core contained the largest crystals of beryl. The largest seen measured 2 feet in diameter and 6 feet in length but larger ones were recovered according to operators and mineral collectors. Blue-green beryl is on the hanging-wall side of the core, where it is ordinarily associated with quartz. In places it approaches aquamarine in quality, and some gem stock was recovered in 1942-45. The $\mathrm{BeO}$ content ranges from 13.3 to 13.5 percent. Most beryl on the footwall side of the core is dull blue or green and is associated with plagioclase and quartz. Small glassy green beryl crystals occur in the scrap-mica masses, and orange to golden crystals are found near uranium minerals. The $\mathrm{BeO}$ content of beryl in the scrap-mica masses is 13.1 to 13.4 percent. Beryl adjacent to lenses of phosphate minerals is gray to brown and, except for its crystal form, difficult to distinguish from alteration products of the phosphate minerals. The $\mathrm{BeO}$ content, however, is similar to other beryl in the unit, about 13.4 percent.

The beryl content of the core-margin zone on the footwall side of the core was determined by mineral measurements to be 1.5 percent. On the hanging-wall side of the core, the crystals are larger and, because they have been almost completely removed during mining operations, mineral measurements in these discontinuous lenses are of little value. During operations by the Ashley Mining Corp., most visible chips of beryl were saved, and an estimated 95-percent recovery was made by hand-cobbing.

Potassic feldspar has been mined from the core and the second intermediate zone. The best feldspar was from the large perthite subhedra in the core. Some of these probably contained as much as 350 tons of highquality potassic feldspar free of waste. In November 1949 , that part of the core of the pegmatite still unmined was thickest in the central part of the main opencut, and was thinner to the northeast and south. Additional potassic feldspar has been recovered from the second intermediate zone. Commercial grade potassic feldspar in this unit must be separated from quartz and plagioclase by hand-cobbing.

Sheet mica has beèn recovered in large quantities, but the most promising and easily accessible areas have been worked out and even the dumps have been reworked. The percentage of sheet mica originally in the wall zone is unknown; all rock exposed in 1949 was not mined in earlier operations because the sheet-mica content was too low, and therefore the exposures were 
not representative of that part of the zone formerly mined. The sheet-mica content of the first intermediate zone is variable, but about 1 percent of the muscovite present seems to be of sheet quality. The sheet mica is hard, rum to ruby, and free splitting. Books seen in the wall zone and first intermediate zone are no larger than 3 inches long by 2 inches wide by 1 inch thick, but all outcrops observed are low-grade areas left during mining operations. Sterrett (1923, p. 133) reported one book of mica 4 feet 2 inches long and 28 inches wide and another 2 feet in diameter and 2 feet thick. Scrap mica can be recovered from the coremargin zone by hand-cobbing from aggregates having a very high muscovite content. Muscovite of scrap quality is a constituent of all units in the pegmatite except the core, but it could be recovered from most of these units only by milling methods.

A small tonnage of phosphate minerals, mostly triphylite from lenses in the core-margin zone, may have been used for experimental work on a process to recover lithium. There is no published record of the result of these investigations.

Secondary uranium minerals are present in extremely small quantities at places in the core-margin zone. These are in scrap-mica masses and commonly are associated with golden beryl and dark-gray quartz.

\section{KEENE DISTRICT}

Many pegmatites of the Keene district have long been of economic importance. They have been an intermittent but important source of sheet mica and feldspar since about 1810 when the Big mine was first opened. Some beryl has been recovered as a byproduct of feldspar and mica mining since the late 1930's, but before that time there was little demand for it. Most mines in this district were studied in detail in 1942-45; for the purpose of this report, the Chickering mine and the Beryl Mountain mine were examined.

\section{BERYL MOUNTAIN MINE}

Beryl Mountain (pl. 2) is in the town of Acworth, 0.8 mile S. $32^{\circ} \mathrm{W}$. of South Acworth village, Sullivan County. One of the two pegmatites present is a wellknown mineral collecting ground, and many descriptions of the minerals have been reported (Shepard, 1830, p. 353-360; Teschemacher, 1844, p. 191-192; 1847, p. 87-89; Holden, 1918, p. 199-200). The beryl-bearing pegmatite was first mined by a Mr. Bowers before 1844 (Jackson, 1844, p. 59, 182) and has been operated intermittently since that time. It was not operated during World War II, despite the increased demand for beryl at that time. In May 1949, H. A. Ashley bought the mine from Miss Sadie A. Cohen, long-time owner, and began operations that resulted in the production of a large but unrecorded tonnage of easily handcobbed beryl. Although the date he ceased mining is not known, it probably was about 1953.

The pegmatites were studied by H. M. Bannerman in 1942 (Cameron and others, 1954, p. 276), when much of the beryl-bearing pegmatite was mapped by him and J. B. Headley, Jr. In 1943, the Bureau of Mines cleared the floor of the largest opencut and drove a 50-foot exploratory adit beneath the floor. S. B. Levin, who was in charge of the project, mapped and studied part of the pegmatite (Levin, 1948).

The two large pegmatites were mapped in 1948 by $\mathrm{J}$. J. Page and L. F. Dellwig. Details of the rich beryl deposit exposed at that time are shown on plate 2. After the mine was reopened in 1949 by H. A. Ashley, the mine was remapped by Page and P. K. Brown, Jr. (pl. 2). In June 1955, probably about 2 years after Ashley ceased operations, the map of the mine was brought up to date during a 2-day field study by L. R. Page and D. M. Larrabee (pl. 2).

The mine is an opencut about 140 feet long, from 20 to 40 feet wide, and as much as 40 feet deep. Small underground workings extend westward from the opencut. The pegmatite also has been exposed in two shallow trenches near the northeast end, and in several shallow pits near the hilltop south of the main working.

The pegmatites on Beryl Mountain are discordant to the enclosing biotite gneiss and amphibolite. Amphibolite has been altered to a granulitic rock extending as much as 3 feet from the contact. The attitude of foliation varies greatly, as shown on plate 2 . The average strike is northeast, and the dip is commonly to the east or southeast. The plunge of minor folds generally is $10^{\circ}$ to $15^{\circ} \mathrm{NE}$.

The pegmatite west of the mine is about 700 feet long, and its outcrop width is about 50 feet. It strikes northeast and dips steeply southeastward. A small shallow opencut has been made in the northeastern part of this pegmatite. This body consists of a thin border zone, a wall zone of plagioclase-quartz-perthite pegmatite, and an apparent core of perthite-quartz-plagioclase pegmatite.

The main beryl-bearing pegmatite spanning the summit of Beryl Mountain trends northeast, dips steeply southeast, probably has a length of more than 1,100 feet, and is exposed over a maximum width of about 180 feet.

The pegmatite probably plunges $10^{\circ}$ to $15^{\circ} \mathrm{N} .30^{\circ} \mathrm{E}$., parallel to rolls in the pegmatite contact and to the arches in the bottom of the quartz core as shown in sections $C-C^{\prime}$ to $G-G^{\prime}$ (pl. 2). The estimated maximum depth of the bottom of the pegmatite is about 100 feet. 
A very narrow border zone, absent in places, surrounds a thick wall zone of plagioclase-quartz-perthite pegmatite. This latter zone consists of about 60 percent plagioclase, 30 percent quartz, 10 percent perthite, and minute quantities of muscovite books less than 2 inches in diameter and black tourmaline crystals less than 4 inches long.

Plagioclase-muscovite-quartz-perthite-beryl pegmatite comprises the intermediate zone, which has an average thickness of about 2 feet but is as much as 7 feet thick near the hilltop south of the mine face. The most distinctive characteristic of this zone is the large quantity of muscovite in wedge-shaped crystals. The composition of the zone is about 35 percent plagioclase, 30 percent muscovite, 25 percent quartz, 5 percent perthite, and 5 percent beryl (13.8 to 14.0 percent $\mathrm{BeO}$ ). Locally the zone may be much richer in any single constituent, as for example: 90 percent plagioclase, 80 percent muscovite, 90 percent quartz, 20 percent perthite, or 30 percent beryl. Grain sizes vary greatly; the largest sizes observed are: plagioclase aggregates, 2 by 6 feet; muscovite books, 1.5 feet in diameter; quartz aggregates, 5 feet in diameter; perthite crystals, 5 feet in diameter; and beryl crystals, 1.5 by 6 feet.

The core consists of white granular quartz containing irregular streaks of pale-rose quartz. The quartz grains are less than one-eighth inch in diameter. The outer part of the core in places contains perthite crystals as much as 20 feet long. Locally, fracture fillings of quartz from the core invade the intermediate zone. Where the perthite-rich parts of the core are absent and the mica-rich intermediate zone is in contact with the core, beryl crystals extend into the core as much as 7 feet. The core has a length of 500 feet and a maximum thickness of about 60 feet; the average thickness is about 25 feet.

A unit of perthite-quartz-plagioclase lithologically similar to the apparent core of the western pegmatite occurs south of the main opencut and along the east side of the pegmatite. In some places this is within the wall zone but in others it is between the wall zone and eastern, hanging-wall contact.

In the south face of the opencut, the quartz core arches over the wall zone, the axis of the arch plunging $10^{\circ}$ to $15^{\circ} \mathrm{N} .30^{\circ} \mathrm{E}$. This is a remnant of the quartz saddle so well exposed in earlier operations. Here the wall zone on the southeast side of the cut pinches out to the northeast, the end plunging $15^{\circ} \mathrm{N} .30^{\circ} \mathrm{E}$., as shown by rolls in the quartz and wall-zone surfaces. To the southeast this sliver of quartz core and intermediate zone pinches out.

Most beryl of the intermediate zone is blue green, but some is olive to brown and some nearly golden (pl. 2). The beryl is coarse grained, euhedral, and although in places rimmed with plagioclase, nearly all of it can be broken free by hand-cobbing. Crystal measurements made in 1955, after the most accessible beryl had been removed by mining, indicated the following beryl content in the intermediate zone and outer part of the core:

\begin{tabular}{l|r|r}
\hline \multicolumn{1}{c|}{ Location } & Percent & $\begin{array}{r}\text { Area of rock } \\
\text { measured } \\
\text { (square feet) }\end{array}$ \\
\hline $\begin{array}{l}\text { West side of high point } \\
\text { North end of main cut. }\end{array}$ & $\begin{array}{r}4.5 \\
\text { Roof of underground working on main } \\
\text { floor of cut_... }\end{array}$ & 216 \\
\hline
\end{tabular}

Thus the average beryl content is about 5 percent.

The intermediate zone is about 300 feet long; it has an average thickness of 2 feet, and probably has an average depth of 25 feet where unmined. In most places this zone is in contact with the quartz core. Thus, the total thickness of the beryl-bearing pegmatite is about 6 feet. Recovery of most of this beryl will require underground mining methods; the present opencut cannot be expanded economically.

Most of the potassic feldspar of the outer part of the core has been removed during past operations but some hand-cobbable material remains southwest of the large opencut. Scrap mica could be recovered by hand-cobbing as a coproduct with beryl of the intermediate zone. Much clean quartz remains east of the exploration adit and south of the opencut; samples of especially pure material analyzed for the New Hampshire State Planning and Development Commission (Meyers, 1941) had a content of 99.38 percent $\mathrm{SiO}_{2}, 0.30$ percent $\mathrm{Al}_{2} \mathrm{O}_{3}$, and 0.016 percent $\mathrm{Fe}_{2} \mathrm{O}_{3}$.

\section{CHICKTERING MINE}

The Chickering feldspar mine is 2.3 miles N. $83^{\circ} \mathrm{E}$. of Walpole village, in the town of Walpole, Cheshire County. The mine was last worked for potassic feldspar in about 1925 by the Whitehall Co., Inc. The irregular opencut is 80 feet long and as much as 70 feet wide. The highest point on the rim of the cut is about 40 feet above the floor. The cut is now used to store water for fire protection, and the water ranges from 5 to 20 feet in depth depending on the rainfall. A prospect pit 20 feet long, 10 feet wide, and as much as 15 feet deep is 50 feet south-southeast of the main cut.

The size of the Chickering pegmatite can only be estimated because the eastern (hanging-wall) contact and the northern and southern ends are not exposed (pl. 3). The pegmatite can be traced for 350 feet 
N. $20^{\circ}$ W., which probably is the average strike of the body. It is at least 80 feet thick and dips eastward about $50^{\circ}$. The plunge of linear elements in quartzmica-staurolite schist of the wallrock is $10^{\circ}$ to $12^{\circ} \mathrm{SE}$., but small rolls on the footwall contact of the pegmatite plunge $5^{\circ}$ to $10^{\circ} \mathrm{N} .20^{\circ} \mathrm{W}$. The south end of a smaller pegmatite crops out 75 feet west of the opencut. It trends N. $20^{\circ}$ W. and is at least 130 feet long and 18 feet wide. Its dip is unknown.

Five units have been mapped in the Chickering pegmatite. One of these contains spodumene, lepidolite, and beryl. This is the only pegmatite in the Keene district where these minerals are known to be constituents of a single unit. The border zone consists of very fine grained quartz-muscovite-plagioclase pegmatite. The zone is commonly only a few inches thick, and can be shown on the map (pl. 3) only on a dip slope at the west side of section $A-A^{\prime}$. The plagioclase is $\mathrm{An}_{2-4}$.

The wall zone is fine- to medium-grained plagioclasequartz-perthite pegmatite. Plagioclase $\left(\mathrm{An}_{2-3}\right)$, including cleavelandite, is about equal in abundance to quartz, and each is nearly twice as abundant as perthite. Muscovite is an accessory mineral. The smaller pegmatite body consists entirely of material similar to the border and wall zones of the main pegmatite.

The first intermediate zone is medium- to coarsegrained quartz-cleavelandite-perthite pegmatite. The average composition is 45 percent quartz, 30 percent cleavelandite $\left(\mathrm{An}_{1-3}\right)$, and 20 percent perthite. Muscovite is the chief accessory mineral, and black, blue, and green tourmaline and apatite are minor accessory minerals. Cleavelandite occurs as veinlets cutting the coarser grained perthite and also forms rims around perthite. Quartz and muscovite comprise the finer grained matrix between the perthite-cleavelandite masses.

The second intermediate zone consists of the same essential minerals as the first intermediate zone but with the addition of accessory spodumene, lepidolite, beryl, columbite, and several phosphate minerals; the texture is also similar. This zone is discontinuous and on the footwall side of the pegmatite, its average thickness is 2 feet; on the hanging-wall side, it is as much as 10 feet thick, but its average thickness is much less. The small isolated patches of the unit shown on plate 3 are either at the margin of the core or in a position that could have been marginal to the core before its removal by erosion or mining.

Crystals of spodumene are more abundant than crystals of other accessory minerals, but nearly all the spodumene has been completely altered to a very fine grained aggregate of muscovite and quartz. Locally 15 to 20 percent of the pegmatite of this zone consists of spodumene crystals as much as 2 feet long, 6 inches wide, and 4 inches thick. Lepidolite is much less abundant than altered spodumene. It is commonly gray and occurs in small, very fine grained irregular aggregates. Beryl (12.4 to 13.1 percent $\mathrm{BeO}$ ) is white, and difficult to distinguish from some of the feldspar, quartz, and amblygonite. A few small plates of columbite are present. Spodumene and lepidolite are most abundant in the inner half of the zone, whereas beryl is most abundant in the outer half; in a few places, these minerals occur together.

Phosphate minerals, commonly triphylite but also less abundant amblygonite and apatite, occur in isolated exposures of quartz-cleavelandite-perthite pegmatite. Sulfides and carbonates, probably mostly siderite, are commonly associated with the phosphates. The approximate outline of the phosphate- and carbonatebearing parts of the zone are commonly indicated by brown- to black-stained areas colored by iron and manganese oxides derived from the weathering of these minerals.

The core is medium- to coarse-grained perthitequartz-plagioclase pegmatite in which the perthite content exceeds 50 percent. Quartz is almost twice as abundant as plagioclase.

Beryl occurs only in the second intermediate zone, where it is most abundant in the outer half. The beryl is white and very difficult to distinguish. The size of the crystals is such that a recovery of 75 percent might be obtained by hand-cobbing if the workers were skillful in recognizing the beryl. Mineral measurements indicate that the average beryl content of the zone is 0.11 percent. The beryl contains 12.4 to 13.1 percent $\mathrm{BeO}$.

The largest potassic feldspar resources are in the core, where the crystals are sufficiently large to permit recovery by hand-cobbing. The perthite in other units could be recovered only by milling. Much of the perthite in the opencut is heavily stained by iron and manganese oxides from the phosphate-carbonate-sulfide aggregates of the second intermediate zone; this staining may disappear a few feet below the surface, but the iron- and manganese-bearing minerals are sufficiently abundant in this unit to require their separation in concentrating potassic feldspar.

Sodic feldspar is present in all units, but the grain size is too small to permit an economic recovery by hand-cobbing. By the use of milling methods, sodic feldspar could be recovered with potassic feldspar.

No sheet mica was seen at the Chickering mine. Scrap mica could be recovered from all units except the core by milling. Most of the muscovite occurs in books and flakes too small to be recovered by handcobbing. 


\section{RAYMOND REGION}

Many pegmatites are in the general vicinity of Raymond village, and four of the most important ones are described in this section. These are all northeast of the smaller Raymond district (p. 19). Several have been prospected or mined for feldspar and associated minerals. Nearly all such activity was by the Whitehall Co., Inc., after World War II.

\section{CORSON MINE}

The Corson feldspar mine is in one of the most important pegmatites in the Raymond region. It is in the town of Nottingham, Rockingham County, 3.9 miles N. $45^{\circ}$ E. of Raymond village. The mine was operated by the Whitehall Co., Inc., during their postwar activity in the Raymond region, and until operations ceased in 1948, the mine supplied feed for the mill at the Chandler mine, 3 miles southwest of Raymond. Workings consist of an opencut 70 feet long, 25 to 40 feet wide, and 10 feet deep, and two small prospect pits.

Two pegmatite bodies, perhaps connected below the surface, crop out at the mine (pl.4). The northeastern body, containing the main opencut, is the larger and better exposed. The main part of this pegmatite is 100 feet long and 65 feet wide, but an offshoot as much as 30 feet thick extends 80 feet farther to the south. Contacts of this irregularly shaped pegmatite are generally discordant to bedding in the interbedded micaquartz schist and lime-silicate country rocks. The dip is probably nearly vertical, but there are many variations in the attitudes of the contact. The plunge is unknown, but the pegmatite may parallel a minor fold in schist that plunges $60^{\circ} \mathrm{S} .25^{\circ} \mathrm{W}$. The second pegmatite, 50 feet southwest of the opencut, is nearly circular, with a diameter of about 50 feet. The attitude of this body is unknown.

Four pegmatite units have been mapped at the Corson mine, and two others, a thin border zone and a late fracture filling, are not shown on plate 4 . The second intermediate zone, consisting of quartz-cleavelanditemuscovite pegmatite, crops out only in and near the opencut, but the other zones are present in both pegmatites.

The border zone consists of very fine grained quartzmuscovite pegmatite with accessory plagioclase. The unit is from one-quarter to 2 inches thick.

The wall zone is fine- to medium-grained plagioclasequartz-perthite pegmatite with accessory muscovite and minor accessory biotite and garnet. The average composition is 55 percent plagioclase, 30 percent quartz,
10 percent perthite, and 5 percent accessory minerals. About one-fourth of the plagioclase is cleavelandite. Muscovite constitutes as much as 5 percent of the unit, but the average content is 1 percent. Very thin radiating strips of biotite 2 to 3 inches long and 1 inch wide are exposed in small areas within the unit. The thickness ranges from 6 inches to 30 feet in the offshoot from the main pegmatite.

The first intermediate zone is medium- to coarsegrained plagioclase-perthite-quartz pegmatite with accessory muscovite. The average composition is 55 percent plagioclase, 30 percent perthite (including some graphic granite), 10 percent quartz, and 5 percent accessory minerals. About one-fourth of the plagioclase is cleavelandite.

The second intermediate zone is medium-grained quartz-cleavelandite-muscovite pegmatite forming a discontinuous unit between the first intermediate zone and the core. Its average composition is 75 percent quartz, 10 percent cleavelandite, 10 percent muscovite, and 5 percent accessory minerals including perthite and beryl. This is the only zone containing beryl.

A 2-inch fracture filling of quartz-beryl pegmatite cuts the second intermediate zone. It contains many small yellow beryl crystals arranged normal to its walls; one crystal extends almost completely across the unit.

The core consists of coarse-grained quartz-perthite pegmatite with accessory muscovite and plagioclase. The average composition is 75 percent quartz, 20 percent perthite, and 5 percent accessory minerals. Perthite is in euhedral to subhedral blocks in the gray quartz. In the southwest pegmatite, a small exposure of similar rock is surrounded by the wall zone rather than being within the first intermediate zone.

The beryl content of the second intermediate zone is 0.15 percent, and most of it could be recovered only by milling. Most beryl crystals are less than 1 inch long, but a few are as much as 8 inches long. They are yellow, yellow-green, or golden. Columbite plates as much as 1 inch long, 1 inch wide, and one-half inch thick are rare in the second intermediate zone.

Potassic feldspar can be recovered from the core by hand cobbing, and a small amount of the perthite in the first intermediate zone can be recovered. These units would not support mining operations under the economic conditions of 1950, and the resources of both potassic and sodic feldspar could be more efficiently recovered by milling methods. The pegmatite is too small to support a mill that is not also supplied by other nearby pegmatites. No sheet mica was seen at the mine, and the scrap mica could be recovered only by milling. 


\section{MCGALL MINE}

The McGall feldspar mine is in the town of Raymond, Rockingham County, 1.0 mile S. $5^{\circ}$ E. of Raymond village. The mine was opened by the Whitehall Co., Inc. in September 1948 and was worked until March 1949 when all mining activity ceased. Workings consist of an opencut 100 feet long, 35 to 80 feet wide, and as much as 25 feet deep, and three small prospect pits.

Two large and three small pegmatites crop out at the mine (pl. 5). The opencut was developed in an ovaloid pegmatite, 110 feet long and as much as 70 feet wide, that strikes about N. $20^{\circ} \mathrm{W}$. The contacts dip outward at angles ranging from $55^{\circ}$ to $75^{\circ}$ except on the east side where the dip is $70^{\circ}$ inward. The pegmatite is generally discordant to the bedding in the quartzmica schist wallrocks, but in places it is parallel to an induced foliation present in the wallrock within a few feet of the contact. The plunge of minor folds and lineation in the wallrock adjacent to the pegmatite ranges from $15^{\circ}$ to $40^{\circ} \mathrm{SW}$.

The largest pegmatite is a lenticular body 320 feet long and as much as 60 feet wide. It is generally discordant, trends due east, and dips $55^{\circ}$ to $65^{\circ} \mathrm{S}$. at the east end, and $65^{\circ}$ to $75^{\circ} \mathrm{N}$. at the west end. A roll in the north contact 100 feet east of the west end of the pegmatite plunges $40^{\circ} \mathrm{NE}$. This is the only feature indicating a possible plunge of the body.

A smaller pegmatite southwest of the larger opencut, having no exposed contacts with wallrock, is known only from outcrops. A pegmatite 1 foot thick and at least 10 feet long is exposed in the east wall of the opencut, 7 feet south of the probable contact of the main pegmatite. It strikes about east and dips $50^{\circ} \mathrm{S}$. Another small pegmatite crops out 30 feet north of the east end of the largest pegmatite. No contacts are exposed, but the two small outcrops trend S. $70^{\circ} \mathrm{W}$.

Five pegmatite zones have been distinguished at the McGall mine, and all except the border zone are shown on plate 5. Fracture fillings also have been recognized.

The border zone consists of very fine grained quartzmuscovite-plagioclase pegmatite. Although commonly less than one-half inch thick, in places it is as much as 6 inches thick.

The wall zone is fine-grained plagioclase-quartzmuscovite pegmatite with accessory perthite and minor accessory garnet, apatite, beryl, and columbite. The average composition of the zone is 60 percent plagioclase, 20 percent quartz, 10 percent muscovite, and 10 percent accessory minerals. In exposures near the entrance to the main opencut, most of the plagioclase is clevelandite, but elsewhere in the unit cleavelandite is only in isolated patches. This zone is 2 to 3 feet thick along the outer margins of the larger pegmatites, and is the sole constituent of the smaller pegmatites.

The first intermediate zone is medium- to coarsegrained perthite-plagioclase-quartz pegmatite with accessory muscovite and minor accessory beryl, garnet sphalerite, and pyrite. The average composition is 45 percent perthite, 35 percent plagioclase, 15 percent quartz, and 5 percent accessory minerals. Perthite is commonly coarse grained, and set in a matrix of plagioclase, quartz, and muscovite. Part of the perthite is in graphic granite. Cleavelandite and normal plagioclase are about equally abundant. The first intermediate zone is the largest unit exposed in the two main pegmatites.

The second intermediate zone is medium-grained quartz - muscovite - perthite - spodumene - cleavelandite pegmatite. The average composition is 40 percent quartz, 20 percent muscovite, 15 percent perthite, 15 percent spodumene, and 10 percent cleavelandite. This zone is exposed only in the opencut where it surrounds the northwestern exposure of the core of the pegmatite. It is 2 feet thick.

The core is medium- to coarse-grained quartzspodumene pegmatite. Grain measurements in the core give an average composition of 86 percent quartz, 13 percent spodumene, and 0.74 percent beryl. Columbite and triphylite are minor accessory minerals. Two segments of the core are in the opencut, one on the northwest wall of the cut and the other on the south and southeast walls. These segments are not now connected although they are reported by the operator to have formed a continuous unit across the cut at one stage of mining operations. The core has an average thickness of 2 feet.

The large pegmatite has a central unit of quartz pegmatite, 25 feet long and 2 feet thick, near its east end. Although spodumene is a minor accessory mineral, this unit is otherwise similar to the core of the pegmatite in the opencut. Quartz pegmatite also occurs as pods or fracture fillings in the prospect pit near the north contact.

A few tabular fracture-controlled units of quartzrich pegmatite cut the first intermediate zone in the opencut. Beryl and muscovite are minor accessory minerals. Small vugs at the ends of these units are lined with crystals of plagioclase and quartz.

Beryl is most abundant in the core, and possibly extends into the second intermediate zone. It is also present as a minor accessory mineral in the wall and first intermediate zones, and in fracture fillings. In the core, beryl is yellow to yellow-green. The average surface area of individual crystals is about 20 square inches, and most crystals could be recovered by hand- 
cobbing. Grain measurements indicate that the grade is 0.74 percent. Crystals of light-green beryl as large as 7 by 7 inches occur in the wall zone, but most crystals are less than 1 inch in diameter and are widely scattered throughout the unit. This fine-grained beryl could be recovered only by milling methods. The major resources of beryl depend on the size of the cores of the two main pegmatites at depth; reports from miners indicate that the core segments in the opencut decreased in size with depth. There is no evidence of a possible increase in size of the core of tha larger pegmatite.

Potassic feldspar resources at the McGall mine are in the first intermediate zone. The coarsest grained perthite is in the walls of the opencut, but it is neither sufficiently abundant nor large enough to warrant its recovery by hand-cobbing under economic conditions of 1949. Most of the feldspar was trucked to the mill at the Chandler mine, crushed, and separated from waste rock on picking belts. Potassic and sodic feldspar, with scrap muscovite as a byproduct, might be recovered by milling.

Sodic feldspar, present in all units of the pegmatites, is most abundant in the wall zone. The grain size of plagioclase in the pegmatites is too small to permit hand-cobbing, and recovery would be possible only by milling.

No sheet mica was seen at the mine. The wall zone contains a greater percentage of scrap mica than other units, but the largest resources are in pegmatite of the first intermediate zone, because of its greater size.

Spodumene is present in the core and second intermediate zones, and resources, like those of beryl, depend on an increase in the size of the two inner units at depth. Spodumene in the core is hard and fresh where cnclosed by quartz but is soft and altered to muscovite where enclosed by feldspar. The spodumene content of the core is 13 percent.

Columbite is a very minor accessory mineral of the core and wall zones. The grains are very small and could not be recovered by hand-cobbing.

\section{MCMULLEN PROSPECT}

The McMullen feldspar prospect consists of three pegmatites 1.0 mile S. $12^{\circ} \mathrm{W}$. of Raymond village, and about 0.3 mile west of the McGall mine. The prospect was worked by the Whitehall Co., Inc., for a few weeks in September and October 1948. A shallow opencut is 100 feet long, 10 to 75 feet wide, and has a maximum depth of about 10 feet. The northeast ends of the northern and central pegmatites were mined.

The three pegmatites are parallel, but arranged en echelon so that the southern pegmatite extends farther east than the others. The bodies are lenticular, concordant, 220 to 260 feet long, and 2 to 40 feet thick.
They strike N. $70^{\circ} \mathrm{E}$., dip vertically or steeply southward, and probably plunge $1^{\circ}$ to $15^{\circ} \mathrm{SW}$. The wallrock is quartz-mica schist. A concordant mafic dike 10 feet thick is between the central and southern pegmatites.

Most of the mining has been in the central pegmatite, which consists of two poorly defined zones. An irregular core of quartz-perthite pegmatite in the center is surrounded by fine- to medium-grained plagioclasequartz-perthite pegmatite containing accessory muscovite and minor accessory beryl. The average composition is 45 percent plagioclase, 40 percent quartz, and 15 percent perthite. On the south wall of the cut, small irregular areas of very fine grained aplitic material occur in the matrix between perthite blocks. This matrix consists of plagioclase $\left(\mathrm{An}_{8}\right)$, quartz, and garnet, and is separated from perthite by a thin layer of cleavelandite $\left(\mathrm{An}_{2}\right)$. About two-thirds of the plagioclase in this unit is cleavelandite. Measurements of beryl grains across the west wall of the opencut indicate a grade of 0.08 percent. Most of the beryl is in crystals less than 1 inch in diameter although 1 crystal, possibly from the core, may have been 1 foot in diameter.

Production of pegmatite minerals from the McMullen prospect will depend on the use of milling methods. Perthite is not sufficiently abundant for hand-cobbing, and plagioclase, scrap mica, and beryl are too fine grained to be recovered economically by hand methods.

\section{VATCHER PROSPECT}

The Vatcher feldspar prospect is 2.5 miles N. $50^{\circ} \mathrm{E}$. of Raymond village. In 1947, the Whitehall Co., Inc., removed the overburden from much of the pegmatite and opened two small prospect pits in search of potassic feldspar (pl. 6).

The pegmatite is at least 400 feet long and 90 feet in outcrop width. The strike of the hanging-wall contact, the only one visible, is about $\mathrm{N} .60^{\circ} \mathrm{E}$., and the dip is $30^{\circ}$ to $60^{\circ} \mathrm{SE}$. The pegmatite is concordant with bedding in the mica-quartz schist. The plunge of the pegmatite appears to be about $20^{\circ}$ in an easterly direction. The footwall contact is not exposed nor is the extension of the pegmatite southwestward from the area mapped. A very fine grained, highly altered mafic dike 7 inches thick strikes N. $45^{\circ} \mathrm{W}$. across the pegmatite and dips $30^{\circ} \mathrm{SW}$.

A thin border zone of very fine grained quartzmuscovite-plagioclase pegmatite is present along the hanging-wall contact. It is less than 6 inches thick, and locally is less than 1 inch thick. The exposures shown on the map (pl. 6) have been exaggerated in order to be shown. The average composition is 55 percent quartz, 20 percent muscovite, 20 percent plagio- 
clase, and 5 percent accessory minerals including cleavelandite, beryl, and garnet.

The wall zone consists of fine- to medium-grained plagioclase-quartz-perthite pegmatite with accessory muscovite, biotite, and cleavelandite, and minor accessory black tourmaline, garnet, beryl, columbite, and sulfides. The average composition is 40 percent plagioclase, 30 percent quartz, 25 percent perthite, and 5 percent accessory minerals. The relative abundance of the essential minerals in the zone varies widely. The thickness of the zone is unknown, but in many exposures it seems to be a thin cap over the core.

The core is medium- to coarse-grained perthitequartz-cleavelandite pegmatite. It also contains muscovite, blocky plagioclase, and minor accessory beryl, columbite, and garnet. The average composition is 45 percent perthite, 40 percent quartz, and 10 percent cleavelandite. The quartz is gray, pink, and white. Perthite in massive quartz is euhedral, but elsewhere it is in subhedral blocks with a matrix of finer grained quartz and cleavelandite.

The core has been exposed only locally by erosion of the wall-zone cap. The core probably extends the entire length of the pegmatite (pl. 6, section $A-A^{\prime}$ ). Pegmatitic material with a composition similar to that of the core is exposed in roughly tabular fracture-filled bodies extending from the central part of the pegmatite across the wall and border zones to the hangingwall schist. At one place the contact is offset slightly at its junction with the fracture filling.

An irregularly shaped unit of cleavelandite-perthitemuscovite pegmatite near the center of the northeastern part of the pegmatite probably was formed by the replacement of earlier pegmatite, and its composition varies greatly. The pegmatite is fine grained to medium grained, and contains an average of 45 percent cleavelandite, 40 percent perthite, and 10 percent finegrained greenish muscovite. Other minerals include quartz, blocky plagioclase, and minor quantities of garnet and sulfides. The perthite is corroded and veined by cleavelandite. The most noticeable difference in composition between pegmatite of this unit and of the zones is the markedly lower quartz content of the replacement unit.

Southwest of the road, this unit is very irregular, and seems to be later than the pegmatite of the adjacent fracture filling. A few perthite crystals in the fracture filling have been completely replaced by cleavelandite; others are rimmed by cleavelandite. The composition here is about 60 percent cleavelandite, 20 percent perthite, and 15 percent fine-grained greenish muscovite.
Economic possibilities at the Vatcher prospect depend on the size of the core, which contains most of the economically important minerals. If it extends most of the length of the pegmatite, as shown on plate 6 , section $A-A^{\prime}$, the resources of these minerals would be suffciently great to warrant future operations.

Beryl forms 0.38 percent of the core, as determined by mineral measurements. The beryl content of the wall and border zones is 0.01 percent. About 75 percent of the beryl in the core could be recovered by hand cobbing. Virtually no beryl could be recovered from the wall and border zones. The beryl is light green in the outer units and very pale green to white in the core.

The average perthite content of the core is 45 percent, although the fracture fillings may contain only 20 to 30 percent. Although recovery of potassic feldspar by hand-cobbing might be a marginal operation, milling of the entire pegmatite to yield a combined product of perthite and plagioclase might be an economically promising method of recovery. Biotite and garnet, although most abundant in the wall zone, are also present in other pegmatite units, and would be the major contaminants of a feldspar product. The average feldspar content of the entire pegmatite, including both perthite and albite, is about 60 percent.

No sheet mica was seen in the Vatcher pegmatite, but muscovite of scrap quality could be recovered by milling, especially from the replacement unit. A few masses of columbite as much as 2 inches across occur in the core, but the estimated content is less than 0.001 percent of the richest exposure of this unit.

\section{RAYMOND DISTRICT}

The group of pegmatites, called the Raymond pegmatite district in this report (fig. 3) are in the southwest corner of the Raymond region, Rockingham County. The district is about 1.25 miles long and 1 mile wide. All but one of the pegmatites investigated are in the town of Raymond although the area mapped extends southward into the town of Chester. Threequarters of the district is in the southwest corner of the Mount Pawtuckaway quadrangle, and one-quarter is in the northwest corner of the Hampstead quadrangle. The Raymond Road, mostly graveled but partly paved, is near the north edge of the area mapped; a graveled road parallel to the Raymond Road but about 1 mile south of it forms the southern boundary. Two abandoned dirt roads are the approximate east and west boundaries; the one on the west is passable in dry weather, but nearly half the length of the one on the east side is overgrown and impassable. Mine-access 


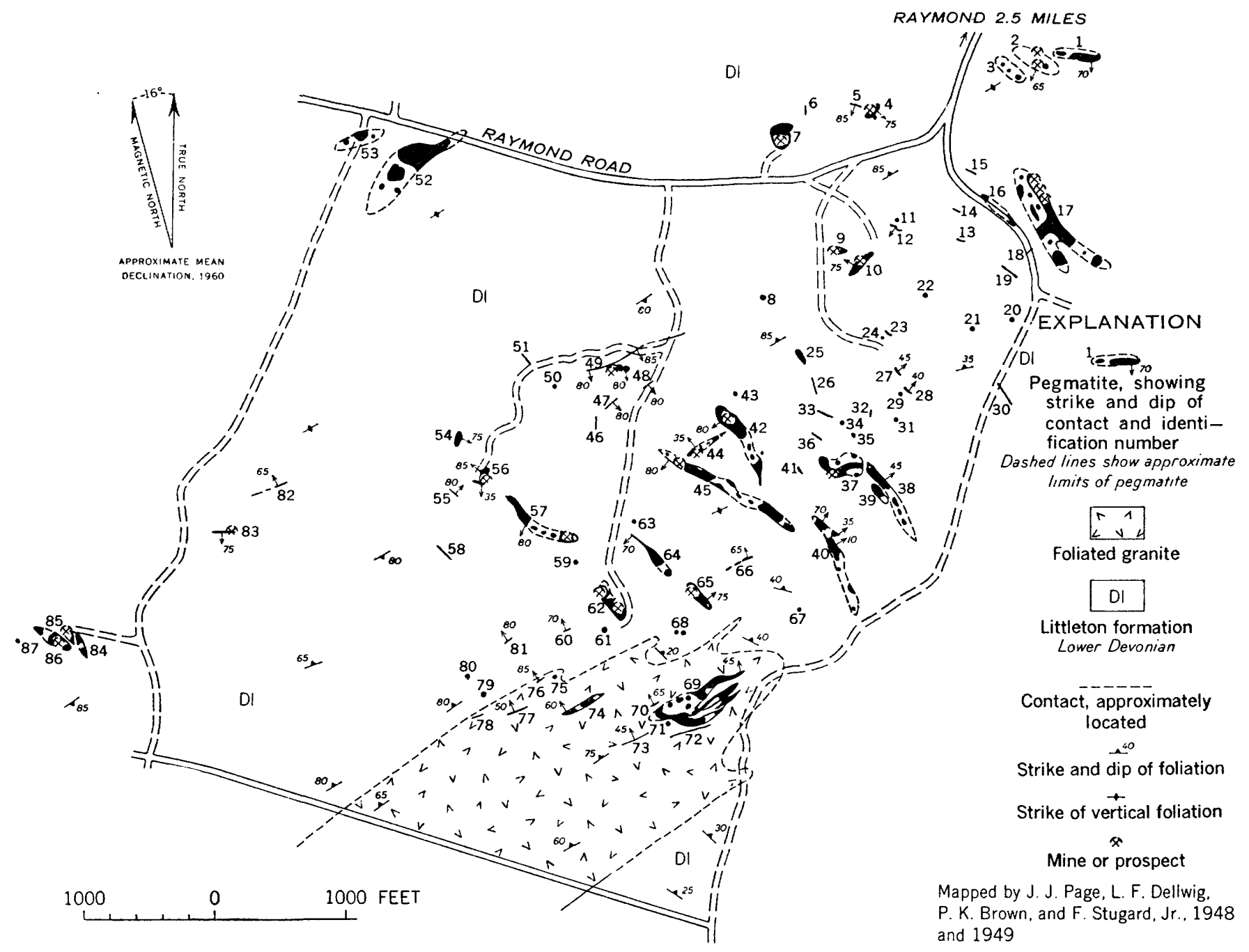

FIGURE 3.-Geologic map of the Raymond district, Rockingham County, N.H., showing locations of pegmatite exposures studied.

roads extend southward from the Raymond Road to mines and prospects that have been operated recently.

The pegmatites of the Raymond district have been known for many years, and a few small prospect pits had been opened before 1942. When further fruitless prospecting was done in search of sheet mica-bearing pegmatites during World War II, the possibility of producing feldspar from these pegmatites was recognized. The Whitehall Co., Inc., through its office in Keene, N. H., began operations in the area during the war, and an extensive prospecting program was carried out after the war in search of commercial deposits of potassic feldspar. Overburden was stripped from several pegmatites, and small prospect pits were opened. Most of the work was done at 4 mines (Chandler, Smith No. 1, Welch, and Blake mines) and at 2 prospects (Smith No. 3, and Hurley prospects). A small mill was established at the Chandler mine, and the coarsely crushed feldspar was separated from waste rock on picking belts. Mining activity in the Raymond district ended in September 1948, but the mill continued to operate until early 1949 using ore from the McGall mine, about 2 miles northeast of the Chandler.

Detailed mapping was done in June July, and August 1948 by the senior author with the assistance of L. F. Dellwig. The larger mines and pegmatites were studied at different times between September 1948 and July 1949. Frederick Stugard, Jr., assisted in the work for 1 week in September 1948, and L. F. Dellwig and P. K. Brown, Jr., assisted in 1949. Mapping was done by pace and compass, and almost every outcrop within the Raymond district was visited. The southwestern part shown on the topographic map of the Mount Pawtuckaway quadrangle was enlarged to a scale of $1: 12,000$ for use as a base map. Selected pegmatites were mapped by planetable and alidade. 


\section{GENERAL GEOLOGY}

The geology of the Mount Pawtuckaway quadrangle has been mapped and studied by Jacob Freedman (1950), who kindly permitted the use of his geologic map before publication. The following brief summary of the general geology of the Mount Pawtuckaway quadrangle in the vicinity of the Raymond district is modified from his work. The district is underlain by metamorphic rocks of the Littleton formation (Lower Devonian). These are metamorphosed sedimentary rocks, consisting largely of mica-quartz schists containing some sillimanite, with interbedded impure quartzite and lime-silicate rocks. The quartzite and lime-silicate rocks probably constitute less than 10 percent of the formation and are commonly in beds less than 1 foot thick. Foliation and bedding in the schists are about parallel. The average strike is $\mathrm{N} .55^{\circ} \mathrm{E}$., parallel to the regional trend of the formation, and the dip is commonly almost vertical.

The south-central part of the district, in the Hampstead quadrangle, is underlain by a fine- to mediumgrained, strongly foliated granitic rock unlike any seen in the Mount Pawtuckaway quadrangle. This gneissic granite consists of feldspar, quartz, and muscovite. Potassic feldspar is almost twice as abundant as plagioclase $\left(\mathrm{An}_{11}\right)$, and together they constitute about 50 percent of the rock. About 30 percent of the rock is quartz, 20 percent is muscovite, and biotite is a minor accessory mineral. Quartz commonly occurs as flat plates, and these, together with flakes of muscovite and biotite, give the rock its foliation.

The schists seem to wrap around the northeast end of the granite body. The strike of bedding in the schists ranges from the regional trend, $\mathrm{N} .55^{\circ} \mathrm{E}$., through north to almost west parallel to the contact between the granite and the schist. In detail, this contact is not concordant to bedding, and apophyses of the granite extend into the schists. Foliation in the granite is parallel to the regional strike, but the dip is consistently $50^{\circ}$ to $80^{\circ} \mathrm{NW}$, in contrast to the steeper dip of the schist.

The location of 87 pegmatite exposures or groups of exposures in the Raymond district are shown in figure 3 , where they are identified by number. Most are in the east half of the area, where outcrops are most abundant.

The pegmatites are exposed along their strike from 2 to 1,200 feet, and are from a few inches to as much as 250 feet thick (table 2). Many of the larger pegmatites are discordant to bedding in the wallrock, although a few are concordant or nearly so.

Most of the pegmatites are lenticular, tabular, or pipelike, but several are so irregular that they cannot be classified under any of these terms. The lenticular and tabular bodies are both concordant and discordant to the structure of the wallrock. Many of the lenticular bodies are so long and thin that they approach a tabular form. The only pegmatite consisting of a series of interconnected lenses is the one at the Smith No. 3 prospect (pl. 10). Apophyses of this pegmatite are good examples of the tabular shape; one apophysis extends more than 500 feet northeastward parallel to bedding, and has a nearly constant thickness for this entire distance. The Chandler pegmatite (pl. 7) is the best example of a pipelike body.

Nearly half of the pegmatites in the Raymond district are concordant to foliation of the enclosing wallrock. All the pegmatites in the gneissic granite are concordant; the average strike is $\mathrm{N} .65^{\circ} \mathrm{E}$., and the $\operatorname{dip} 50^{\circ} \mathrm{NW}$. The average strike of concordant pegmatites in schist is $\mathrm{N}$. $55^{\circ} \mathrm{E}$., and the average dip steeply northwestward. The discordant pegmatites commonly strike N. $40^{\circ}$ to $60^{\circ}$ W., and dip steeply northeastward. In the east-central part of the area, pegmatites of similar strike are generally concordant to bedding that wraps around the northeast end of the gneissic granite body. Pegmatite Nos. 37, 38, 39, and 40 are concordant, northwestward-striking bodies. They dip at angles ranging from $10^{\circ}$ to $70^{\circ} \mathrm{NE}$.

The pegmatites contain varying proportions of plagioclase, perthite, quartz, muscovite, and accessory minerals such as biotite, black tourmaline, garnet, beryl, columbite, spodumene, lepidolite, löllingite, sulfides, and phosphates. Differences in the proportions of the major constituent minerals and differences in texture permit zones to be distinguished in 38 of the pegmatites. Table 3 gives the sequence of mineral assemblages inward from the contact in each of the zoned pegmatites.

Forty-nine pegmatites are not known to be zoned. In most of these the exposures are inadequate for recognition of zones. About half of these pegmatites consist of varying proportions of plagioclase, quartz, and perthite, and in most, plagioclase is more abundant than perthite. Fracture-controlled units were noted in eight pegmatites. These generally consisted of quartz, muscovite, perthite, and plagioclase (commonly cleavelandite). In three pegmatites, these units are zoned.

Beryl from pegmatites in the Raymond district could be a major byproduct of feldspar milling if special equipment were installed to permit its recovery. Most of the crystals are too small for hand-cobbing, although a few tons of beryl could be recovered in this way from the core of the Chandler and a few other pegmatites. Very fine grained beryl was observed in pegmatite 74, and other pegmatites may contain crystals of equal or oven smaller size that have been overlooked. This very 


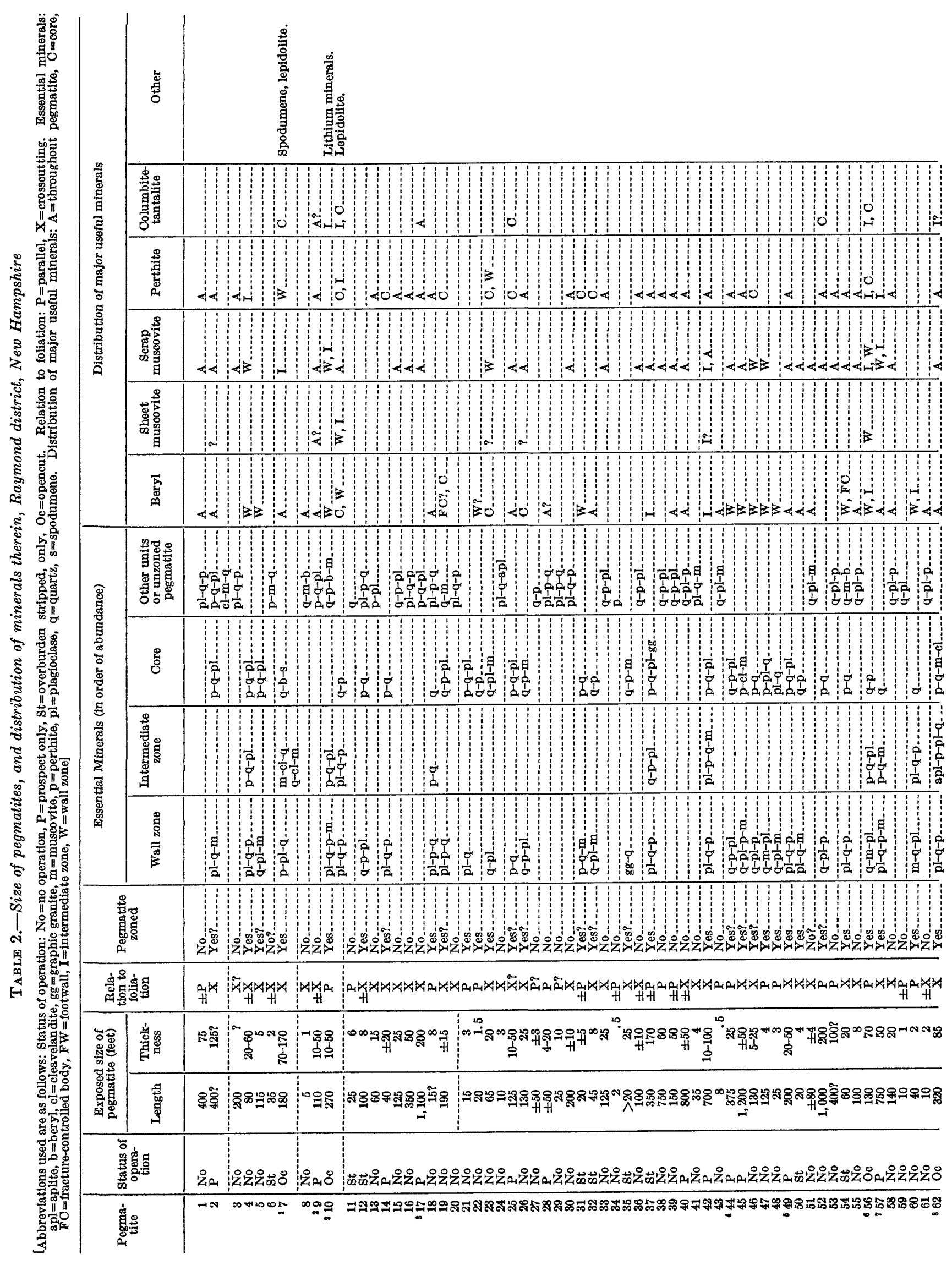




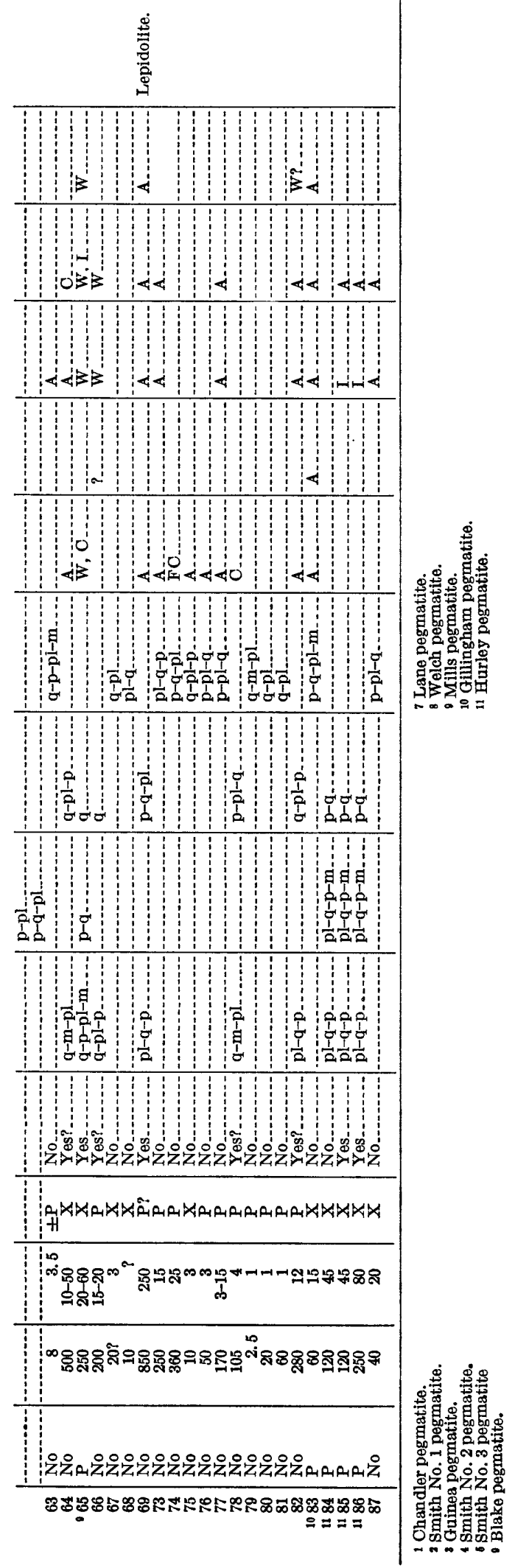


TABLE 3.-Mineral assemblages in zoned pegmatites

[Sequence inward

\begin{tabular}{|c|c|c|c|c|c|c|c|c|c|c|c|c|c|c|c|c|}
\hline & Mineral assemblage & \multicolumn{15}{|c|}{ Pegmatite number } \\
\hline 1 & Plagioclase-quartz-muscovite. & & & & & & & & & & & & & & & \\
\hline 2 & tz-perthite.... & $x$ & $\mid--1$ & -......... & $x$ & 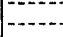 & $x$ & $\cdots$ & & -- & $\cdots$ & $\ldots$ & $\cdots$ & $\cdots$ & $\cdots$ & 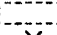 \\
\hline $\begin{array}{l}3 \\
4\end{array}$ & $\begin{array}{l}\text { Quartz-plagioclase-muscovite.-- } \\
\text { Perthite-plagioclase-quartz }\end{array}$ & $-\cdots$ & $x$ & $-x^{--1}$ & & $\mid-\ldots$ & 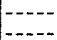 & $\cdots$ & 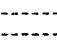 & $\cdots$ & 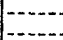 & (n... & $-\ldots . .$. & $-\cdots$ & ( n & $x$ \\
\hline 8 & Plagioclase-quartz.............................. & $\cdots$ & $-\cdots$ & 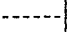 & 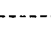 & $-\cdots \cdot-$ & $\cdots-\cdot$ & & 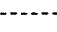 & $\times$ & $-\cdots$ & - & . & $-\cdots+-$ & $\cdots$ & $\cdots$ \\
\hline 10 & $\begin{array}{l}\text { Quartz-plagiociase- } \\
\text { Perthite-quartz-plagioclase-aplite-.. }\end{array}$ & $\ldots$ & $\cdots$ & $\cdots$ & $\ldots$ & $\cdots$ & $\cdots \cdot \cdot-\cdot$ & $\cdots$ & -...- & $\cdots .$. & $\cdots$ & $x$ & $\ddot{x}$ & $\cdots \cdots$ & $\cdots$ & $\cdots$ \\
\hline 11 & Perthite-quartz-muscovite- & - & & & & & & $\cdots$ & $\cdots$ & $\cdots$ & $\cdots$ & $\ldots$ & & $\cdots+\cdots$ & $x$ & \\
\hline 12 & $\begin{array}{l}\text { Quartz } 1 \text { - } \\
\text { Opart-nlagiolasenerthite-muscovite }\end{array}$ & $\cdots$ & $-\cdots$ & 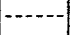 & -.-- & $-\cdots \cdot$ & $\cdots$ & & $\cdots . .$. & $\cdots-\cdots+$ & $\cdots$ & $\cdots$ & $\cdots-\cdots$ & 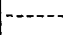 & $-\cdots$ & \\
\hline 13 & $\begin{array}{l}\text { Quartz-plagioclase-perthite-muscovite. } \\
\text { Onartz-olagioclase-nerthite }\end{array}$ & 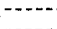 & 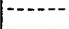 & 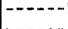 & -..- & $\cdots+\cdots$ & $\cdots+\cdots$ & $\cdots+\cdots$ & -...-. & $-\cdots$ & $\cdots$ & & & $\cdots+\cdots$ & $\cdots+-$ & \\
\hline 15 & 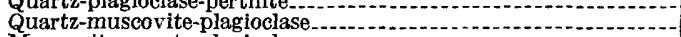 & & 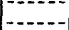 & $\cdots$ & $\cdots . .$. & . & & $\cdots$ & ..... & 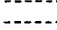 & $\ldots . .$. & $\cdots$ & ..... & 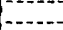 & $\cdots$ & 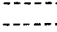 \\
\hline 16 & Musco & & & & & & & & -...-. & & $-\ldots$ & & 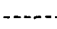 & $\ldots . .$. & 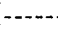 & \\
\hline 17 & Quartz-perthite-plagioclase-muscovite_- & & & & & & & & & & & & & & & \\
\hline
\end{tabular}

Intermedia te zone(s)

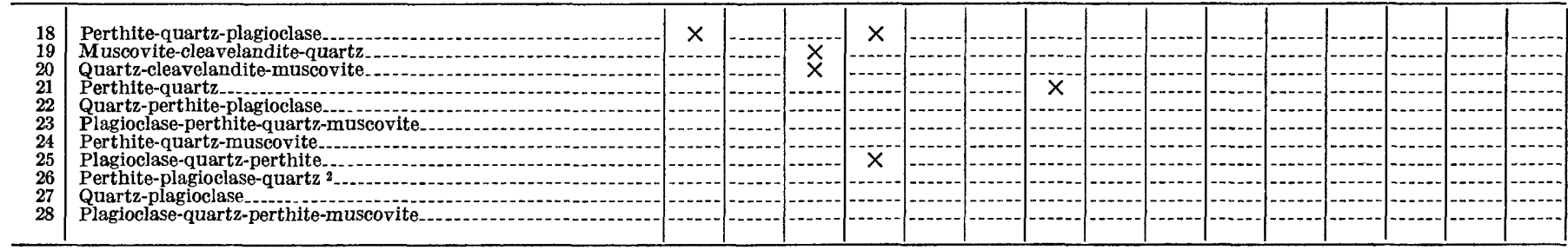

Core

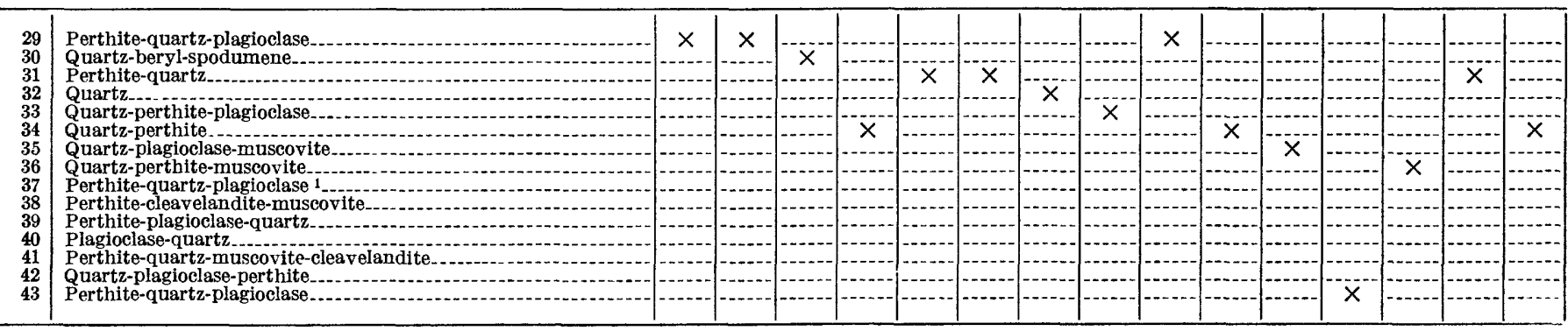

1 In graphic granite. $\quad 2$ In aplite.

fine grained beryl would be recoverable only if a milling method was developed. The composition of the beryl ranges from about 11.6 to 13.5 percent $\mathrm{BeO}$ and averages about 13.0 percent. In 50 pegmatites in the Raymond district, beryl was noted in a total of 56 zones and in some it was present throughout the entire pegmatite. The distribution of beryl-containing units as follows: Wall zone, 15; intermediate zone, 4 ; core, 6 ; fracture-controlled bodies, 3 ; entire pegmatite, 28.

Potassic feldspar was the major product recovered during recent mining activity in the Raymond district and it would be the major product of any future operations under the 1947-50 demand for pegmatite minerals. Perthite is an essential mineral of every large pegmatite in the area. Its grain size, however, is ordinarily too small to permit recovery by hand-cobbing methods. A few pegmatites scattered throughout the area contain coarse-grained, perthite-rich units, but most of these units are so small that they could be mined only by removing large tonnages of finer grained pegmatite in the adjacent units. Resources in any one of these units are at most only a few hundred tons of potassic feldspar.

Beneficiation methods in which potassic and sodic feldspar are recovered by flotation or other means seem to be the only solution for future production. The district is at an economic disadvantage compared with others in New Hampshire because of the small average size of the individual pegmatites and the lack of a resident supply of labor with a knowledge of mining. It is favored, however, by the fairly uniform average composition of the pegmatites, the high feldspar content, and the small and uniform content of iron-bearing accessory minerals which are especially harmful in any feldspar product. The establishment of a mill that is easily accessible from all parts of the area, the use 
of the Raymond District, Rockingham County, N.H.

from the contact]

\begin{tabular}{|l|l|l|l|l|l|l|l|l|l|l|l|l|l|l|l|l|l|l|l|l|l|l|l|l}
\hline \multicolumn{10}{c}{ Pegmatite number-Contiuued } \\
\hline 35 & 37 & 42 & 44 & 45 & 46 & 47 & 48 & 49 & 50 & 52 & 54 & 56 & 57 & 60 & 62 & 64 & 65 & 66 & 69 & 78 & 82 & 85 & 86 & \\
\hline
\end{tabular}
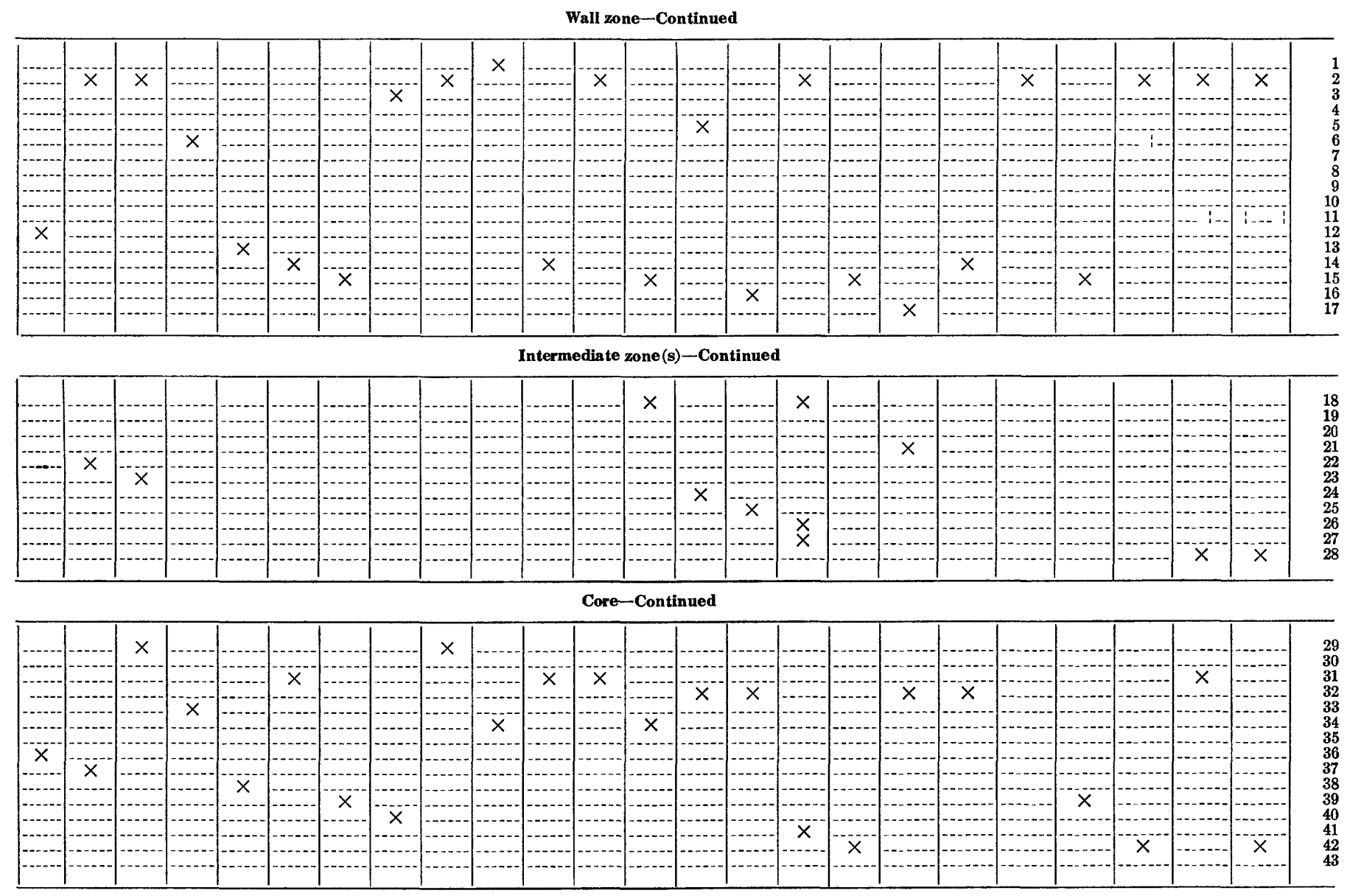

of mining equipment that could be moved easily from one location to another as individual deposits were mined out, and the use of equipment and methods that would permit low-cost mining of large tonnages of rock all would be necessary to insure economic recovery of feldspar.

Sodic feldspar could be recovered only through milling methods, which would yield a product combined with potassic feldspar. The grain size of the plagioclase is too small to permit its recovery by hand-cobbing, and only a small recovery could be obtained by the use of crushing plants and picking belts.

The possibility of recovering muscovite of sheet quality from pegmatites of the Raymond district is very poor. No pegmatite units were seen that would support mining operations solely for sheet mica under prices similar to those in 1942-45. Crude mica books yielding small sheets are present at a few places, but in only one pegmatite (the Blake, pegmatite 56) is there a sufficient concentration to permit economic recovery. Scrap mica can be recovered at 1 or 2 places by hand-cobbing, but most of the muscovite in the pegmatites is too small to be recovered except through milling methods. Muscovite occurs in almost every pegmatite, and the average content probably ranges from 2 to 5 percent. Its recovery as a byproduct of feldspar milling offers the best possibility for future production.

Columbite is most abundant in the core of the Chandler pegmatite where most of it can be recovered by hand-cobbing. In other pegmatites, it is a minor accessory mineral and only a few small plates can be seen. Recovery during feldspar milling could be made by simple gravity methods.

The Chandler pegmatite also contains spodumene and lepidolite in the core, and spodumene in what is 
probably an inner intermediate zone. Much of the spodumene has been altered to muscovite, and present exposures do not indicate sufficient resources to warrant its recovery. Lepidolite resources in the core are also very small. Other pegmatites in the area may contain lithium minerals, but none have been observed.

\section{PEgMatite 1}

Pegmatite 1 is poorly exposed and crops out in an area 75 feet wide and 400 feet long. This body strikes east and dips $70^{\circ} \mathrm{S}$. at the one place where a contact is exposed, and it is generally concordant. It is unzoned fine- to medium-grained plagioclase-quartz-perthite pegmatite. Beryl (12.8 percent $\mathrm{BeO}$ ) is a minor accessory mineral. Possible products are milling-grade feldspar and scrap mica.

\section{PEGMATITE 2}

Pegmatite 2, also poorly exposed, crops out in an area 125 by 400 feet. Two small prospect pits were opened for feldspar near the contacts by the Whitehall Company, Inc. The pegmatite strikes N. $65^{\circ} \mathrm{W}$., dips $65^{\circ}$ SW., and is discordant. It has at least two zones: a wall zone of plagioclase $\left(\mathrm{An}_{12}\right)$-quartz-muscovite pegmatite and a core of medium-grained perthite-quartzplagioclase pegmatite. A small unit in the north pit, apparently not a zone, consists of medium-grained cleavelandite $\left(A n_{1}\right)$, muscovite, and quartz; it contains as much as 30 percent muscovite of scrap quality. Green tourmaline is associated with cleavelandite; "watermelon" tourmaline also has been reported from this pegmatite. Possible products are milling-grade feldspar and scrap mica.

\section{PEgMatite 3}

Pegmatite 3 is represented by several small exposures in an area that extends N. $50^{\circ} \mathrm{W}$. for 200 feet; some may be boulders. The rock is unzoned fine- to mediumgrained plagioclase-quartz-perthite pegmatite. Possible products are milling-grade feldspar and scrap mica.

\section{PEgMatite 4}

Pegmatite 4 is a poorly exposed, very irregular, discordant pegmatite that crops out in an area 50 by 80 feet. The strike is variable, averaging north, and the dip is $55^{\circ} \mathrm{E}$. to vertical. The zoning consists of a thin border zone of very fine grained plagioclase $\left(A n_{10}\right)$ quartz pegmatite, a wall zone from 3 to 25 feet thick of fine- to medium-grained plagioclase $\left(\mathrm{An}_{4}\right)$-quartzperthite pegmatite, and a core of medium- to coarsegrained perthite-quartz-plagioclase pegmatite. The beryl in the border zone, seen only under a microscope, contains 12.95 percent $\mathrm{BeO}$; beryl in the wall zone contains 13.2 to 13.4 percent BeO. Mineral measurements indicate that the wall zone contains 0.06 percent beryl. Possible products are hand-cobbed perthite from the core, and feldspar and scrap mica of milling grade.

\section{PEgMatite 5}

Pegmatite 5 is discordant, poorly exposed, and from $11 / 2$ to 5 feet thick; it is at least 115 feet long, and strikes N. $70^{\circ} \mathrm{W}$. and dips $85^{\circ} \mathrm{SW}$. It consists of a wall zone of medium-grained quartz-plagioclase-muscovite pegmatite and a core of medium-grained perthite-quartzplagioclase pegmatite; the plagioclase of the wall zone is of slightly different composition on the hanging-wall $\left(\mathrm{An}_{4}\right)$ and footwall $\left(\mathrm{An}_{7-8}\right)$ sides of the pegmatite. Beryl is a minor accessory mineral in the wall zone.

\section{PEGMATITE 6}

Pegmatite 6, an irregular body, is exposed in an area 2 by 35 feet. It is a discordant intrusive mass that trends N. $20^{\circ} \mathrm{W}$. and dips $70^{\circ} \mathrm{W}$. It consists of fine- to medium-grained perthite-muscovite-quartz pegmatite that contains small masses of very fine grained plagioclase $\left(\mathrm{An}_{7}\right)$ and quartz.

\section{PEGMATITE 7, CHANDLER MINE}

The Chandler feldspar mine is 2.9 miles S. $52^{\circ} \mathrm{W}$. of the village of Raymond, near the north edge of the Raymond pegmatite district. It was opened in 1946 by the Whitehall Co., Inc., and was operated by them until September 1948. A small crushing plant was built northwest of the mine workings, and the crushed product was passed over picking belts on which feldspar and waste rock were separated. After the closing of the Chandler mine, the plant was operated on material from the McMullen prospect and the McGall mine until the company suspended operations in the Raymond region in early 1949.

The mine was studied by J. C. Olson and J. W. Adams (written communication, 1948) of the Geological Survey in October 1947 and May 1948, respectively, and part of the following description is based on their investigation.

The workings consist of an irregular opencut. The earliest development was a cut 100 feet long, 70 feet wide, and as much as 30 feet deep, which was driven northeastward into a steep hillside. Later work extended this cut southeastward for about 120 feet from the southwest end of the earlier working. It is about 50 feet wide and 20 feet deep and is nearly filled with water.

The pegmatite is irregularly fan shaped (pl. 7) causing the width of exposure to range from 50 feet at the south end to 180 feet at the north end; the northsouth dimension is about 180 feet. The pegmatite is an irregular pipelike body that probably plunges $55^{\circ}$ 
to $60^{\circ} \mathrm{W}$. The contact with mica-quartz schist is commonly discordant, and wide variations in strike and dip were recorded. Several thin schist septa between pegmatite lobes were partly responsible for discontinuing northeastward development of the earlier cut into the hillside.

A dike of fine-grained mafic rock cutting the pegmatite is exposed in the floor and walls of the pit. It strikes N. $60^{\circ} \mathrm{W}$., dips $35^{\circ} \mathrm{NE}$., and is as much as 12 feet thick. This rock weathers much more rapidly than the pegmatite or schist, and a depression has been formed along the strike of the dike. During excavation of the lower pit, 10 to 15 feet of sand and gravel were removed from this depression.

Seven internal structural units have been distinguished in the Chandler pegmatite, but only four are shown in plate 7. The border zone is too thin to map, and two intermediate zones have been mined out. The border zone is very fine grained quartz-muscoviteplagioclase pegmatite. It is a discontinuous zone, rarely more than 1 inch thick.

The wall zone consists of medium- to coarse-grained perthite-plagioclase-quartz pegmatite with accessory cleavelandite and muscovite and small quantites of black tourmaline, beryl, apatite, garnet, and columbite. The composition varies but the average is 45 percent perthite, 30 percent plagioclase, 20 percent quartz, and 5 percent accessory minerals. Plagioclase is most abundant within a fow feet of the wallrock. Blocky plagioclase is predominant near the outer contact and cleavelandite predominates in the inner part of the zone. Irregular bodies of coarse-grained quartz and graphic granite form much of this zone. Small masses of altered spodumene, altered black tourmaline, and lepidolite may have been introduced after consolidation of the wall zone. The roughly tabular shape of some of the lepidolite aggregates and their crosscutting relations to sporadic large perthite crystals indicate that they formed along fractures. The wall zone, at least 30 feet thick, forms most of the exposures at the mine.

The first intermediate zone is a discontinuous unit of medium-grained muscovite-cleavelandite-quartz pegmatite that is exposed only in the southwestern part of the lower opencut. The chief accessory minerals are plagioclase and beryl, but there also are minor black tourmaline and apatite. The average composition is 45 percent muscovite, 30 percent cleavelandite, 15 percent quartz, and 10 percent accessory minerals. The zone is about 5 feet thick.

The second intermediate zone consists of fine- to medium-grained quartz-cleavelandite-muscovite pegmatite with minor accessory beryl, plagioclase, and black tourmaline. The average composition is prob- ably 60 percent quartz, 25 percent cleavelandite, and 15 percent muscovite. Cleavelandite is interstitial to the coarser grained quartz. Muscovite occurs as flakes, small flat books, and as small hemispherical books. The zone is a discontinuous unit with a maximum exposed thickness of 30 feet.

J. W. Adams (written communication, 1947) noted a coarse-grained microcline-rich unit on the northwest and southeast sides of the core in the lower opencut. This unit, the third(?) intermediate zone, was mined out by July 1948. It reportedly consisted mainly of blocky cream-colored microcline. The extent of this unit and its exact position in the zonal sequence are unknown.

The fourth(?) intermediate zone, also mined out, is medium-grained quartz-spodumene-muscovite pegmatite recognizable only from blocks on the dump. In composition it seems to be a transitional unit between the second intermediate zone and the core. The average composition of blocks is 45 percent quartz, 35 percent spodumene and its alteration products, and 20 percent muscovite. About half of the spodumene has been altered to a silvery muscovite, and crystals in all stages of alteration have been found. The extent and position of this unit in the zonal sequence are unknown.

The core is coarse-grained, quartz-beryl-spodumene pegmatite. Its average composition, as determined from mineral measurements, is 80 percent quartz, 10 percent anhedral pink beryl, 5 percent altered spodumene, 3 percent lepidolite, 1.5 percent phosphates, and 0.5 percent columbite. The core is exposed for 50 feet along the southwest wall of the lower opencut. Beryl is most abundant in the central and higher parts of the core, and altered spodumene is mostly in the outer and lower parts. Lepidolite is most common at the edge of the beryl-rich part of the core.

Beryl is present in each of the pegmatite units shown on plate 7. Mineral measurements indicate that the grade of the wall zone is 0.85 percent. The composition of this beryl ranges from 12.6 to 13.0 percent $\mathrm{BeO}$, and most of the specimens are near the higher end of the range. It is light green to white and is too small to be recovered by hand-cobbing.

Beryl occurs in large crystals in the first and second intermediate zones. Much of the beryl is in skeletal crystals with roughly concentric layers of light-yellowgreen beryl, quartz, and cleavelandite parallel to the crystal outlines. Although about 50 percent of the beryl could be recovered by hand cobbing, the $\mathrm{BeO}$ content of the concentrate would be reduced by the impurities in the shells. The average content of beryl in these zones is 0.62 percent, but the grade ranges from 
BERYL RESOURCES OF NEW HAMPSHIRE

10 percent in certain areas of the first intermediate zone to 0.5 percent in the second intermediate zone. The average $\mathrm{BeO}$ content is about 12.5 percent, somewhat lower than that of beryl from the wall zone.

The richest beryl reserves are in the core. Mineral measurements show that the grade is 9.6 percent, nearly all of which could be recovered by hand-cobbing. Pink anhedral masses of beryl, as much as 11 by 18 inches in size, are surrounded by quartz. The $\mathrm{BeO}$ content of this beryl is lower than that in the wall or intermediate zones, ranging from 12.3 to 12.5 percent, thus indicating an increase in the alkali content from zone to zone toward the center of the pegmatite.

Reserves of potassic feldspar at the Chandler mine are only in the wall zone. Although most of the production of hand-cobbed feldspar was from the microcline-rich intermediate unit, this unit was completely mined out, and there are no indications that similar material is at depth. Perthite was recovered from the wall zone by the use of crushers and picking belts for several months prior to September 1948 when the mine was closed. The average perthite content of the wallzone pegmatite is 45 percent, but a satisfactory recovery could be made only by milling and beneficiation.

Sodic feldspar resources are largest in the wall zone, but smaller tonnages could be recovered from pegmatite of the first and second intermediate zones which contain 30 percent and 25 percent cleavelandite, respectively. The grain size of the sodic feldspar in these units is so small (seldom greater than 2 inches in diameter) that these resources could be recovered only by milling in conjunction with the recovery of potassic feldspar.

Muscovite of scrap quality is most abundant in the first intermediate zone, where the average content is 45 percent. About 75 percent of this could be recovered by hand-cobbing. An occasional book might yield a small quantity of sheet mica, but recovery would be limited to a few pounds from each ton of crude mica. The greenish-rum muscovite in this unit is soft, badly cracked, and contains many mineral inclusions. The second intermediate zone contains 15 percent muscovite, and the wall zone contains about 2 percent; scrap mica could be recovered from these only by milling.

Columbite occurs in the core, where mineral measurements indicate the average content is 0.65 percent. The irregular masses are as much as 3 by 5 inches, and most could be recovered by hand-cobbing. Small plates of columbite occur with beryl in the wall zone but could be recovered only by milling; the grade is estimated to be less than 0.001 percent.

Spodumene occurred in the fourth intermediate zone, which is now mined out; the only spodumene remain- ing is in the greatly altered crystals forming about 5 percent of the core. These are as much as 2 feet long, 8 inches wide, and 3 inches thick. Color ranges from white to lilac to olive green.

Lepidolite occurs in very fine grained irregular aggregates that are purple, gray, or green. It constitutes 3 percent of the core, about half of which could be recovered by hand-cobbing.

\section{PEGMATITE 8}

Pegmatite 8 is a discordant, 8 - to 12 -inch-thick body that is exposed for only 5 feet. It strikes N. $60^{\circ} \mathrm{W}$. and dips $80^{\circ} \mathrm{NE}$. It is a quartz-muscovite-beryl pegmatite containing accessory plagioclase. The beryl contains 13.2 percent $\mathrm{BeO}$.

\section{PEGMATITES 9 AND 10, SMITH NO. 1 MINE}

The Smith No. 1 feldspar mine (pl. 8) is 2.95 miles S. $47^{\circ} \mathrm{W}$. of the village of Raymond. The pegmatite was prospected by Cyrus G. Smith of Raymond in 1942, but the major operations for feldspar were begun by the Whitehall Co., Inc., in 1946 and continued into 1947.

The main opencut in pegmatite 10 is 120 feet long, as much as 40 feet wide, and probably about 40 feet deep. A small prospect pit 50 feet southwest of the main opencut is 20 feet long, 10 feet wide, and 5 feet deep. At the southwest end of the pegmatite, an opencut has been driven 50 feet northeastward; it is 20 feet wide and as much as 10 feet deep. This was to have been developed into an incline extending to the bottom of the main cut, but was not completed. An opencut 20 feet wide, 25 feet long, and 10 feet deep, and a small prospect pit were opened in pegmatite 9,200 feet west of the main cut.

Pegmatite 9 is at least 100 feet long and from 10 to at least 50 feet wide. The contact is exposed at only two places, where the strike is N. $5^{\circ} \mathrm{W}$. and N. $40^{\circ} \mathrm{E}$. However, the general trend of the exposures is almost east, discordant to the wallrock. The dip is $55^{\circ}$ to $60^{\circ} \mathrm{W}$. and the plunge of a roll on the contact is $40^{\circ} \mathrm{N} .30^{\circ} \mathrm{W}$. This pegmatite has no known connection with pegmatite 10 .

Pegmatite 10, the main pegmatite, is 270 feet long and as much as 50 feet thick. It pinches out in the southwest opencut and apparently also pinches out a few feet beyond the northeasternmost exposure. It is concordant and strikes N. $40^{\circ}$ E. The dip was measured as $55^{\circ} \mathrm{SE}$. at the southwest end, and $75^{\circ} \mathrm{NW}$. along the northwest wall of the opencut, and it continues to steepen to the north. The average dip is probably about $75^{\circ} \mathrm{NW}$. The plunge of the pegmatite probably is to the northeast, parallel to a roll in the contact that plunges $65^{\circ} \mathrm{N} .25^{\circ} \mathrm{E}$. The bottom, or keel, 
of the pegmatite lens is exposed in the southwest opencut. The outcrop northeast of the main cut has one large schist septum that extends nearly across the pegmatite; this may be a roof pendant near the crest of the lens.

A fault of small but unknown displacement is exposed along the southeast wall of the main opencut and continues as far as the southwest end of the pegmatite. It strikes N. $40^{\circ}$ E., dips $75^{\circ} \mathrm{SE}$.

Six zones have been mapped, and there may be additional unexposed units. The sequence of the exposed units in the pegmatite is obscure because the relations were not distinguishable when they were mapped. The only evidence of fracture-controlled replacement units is the presence on the dump of specimens showing very fine grained lepidolite aggregates similar to those at the Chandler mine. The border zone consists of very fine grained quartz-muscovite-plagioclase pegmatite. It is commonly less than one-half inch thick, therefore it is not shown on plate 8 .

The wall zone is fine- to medium-grained plagioclasequartz-perthite-muscovite pegmatite. The average composition is 45 percent plagioclase, 35 percent quartz, 10 percent perthite, and 10 percent muscovite. Black tourmaline, garnet, apatite, and beryl are minor accessory minerals. It is a discontinuous unit exposed only along the southeast contact of the main pegmatite, where it is as much as 4 feet thick.

The first intermediate zone consists of medium- to coarse-grained perthite-quartz-plagioclase pegmatite. The average composition is 50 percent perthite, 25 percent quartz, and 25 percent plagioclase. Black tourmaline, garnet, apatite, and muscovite are accessory minerals. Perthite crystals as large as 1 by 2 feet are separated by a medium-grained matrix of quartz and plagioclase. This unit is exposed only at the ends of pegmatite 10 , and it is the only mappable unit in pegmatite 9.

A medium-grained unit of plagioclase-quartz-perthite pegmatite, probably the second intermediate zone, is exposed along the northwest wall of the large opencut and extends for a short distance southwest of the cut. The average composition is 40 percent plagioclase, 35 percent quartz, and 25 percent perthite. Muscovite is an accessory mineral, and garnet and apatite are minor accessory minerals. In most exposures, the unit is in contact with the wallrock.

Medium-grained plagioclase-quartz-muscovite pegmatite, probably the third intermediate zone, is exposed in the northwest wall of the opencut, where it is 2 to 4 feet thick. The average composition is 60 percent plagioclase, 35 percent quartz, and 5 percent muscovite. Garnet and apatite are minor accessory minerals.
A unit that seems to be the fourth intermediate zone in the sequence consists of medium- to coarse-grained quartz-perthite-biotite-muscovite pegmatite. The average composition is 50 percent quartz, 30 percent perthite, 10 percent biotite, and 10 percent muscovite. Black tourmaline is an accessory mineral and garnet and columbite are minor accessory minerals. This unit is exposed only at the ends and southeast side of the main opencut, although it is reported by the operator to have formed a hood over the perthite-quartz pegmatite of the core. The hood extended somewhat farther downdip on the southeast side than on the northwest side of the core. On the southeast wall it is between the core and the wall zone, but its relative position to other units on the northwest wall is unknown.

The core is coarse-grained quartz-perthite pegmatite. Most exposures were inaccessible, but the average composition seemed to be about 65 percent perthite and 35 percent quartz. Muscovite, plagioclase, and tiny flakes of autunite and torbernite are accessory minerals. Columbite and beryl may have been recovered from this unit.

The only visible beryl is in the wall and border zones; the grade of the entire pegmatite is probably less than 0.002 percent. Most of the production was probably from the core, where the percentage recovered by handcobbing must have been high, as indicated by the $a b$ sence of fragments or small crystals on the dumps.

The major source of potassic feldspar at the Smith No. 1 mine has been perthite from the core, where recovery was by hand-cobbing. Most exposures of this unit are no longer accessible, but men who worked at the mine stated that potassic feldspar was abundant in the floor of the opencut. Perthite in the vicinity of the fault is stained by iron oxides, but, as plate 8, section $A-A^{\prime}$ shows, the fault dips southward out of the core. Small resources of perthite are present in all other units except the third intermediate zone, but recovery could be only by milling. The common impurities are the iron-bearing minerals that are most abundant in the fourth intermediate zone, which probably does not extend below the level of the present workings.

Sodic feldspar would be recovered with the potassic feldspar in any milling operation using present methods of recovery. The intermediate and wall zones of pegmatites 9 and 10 have the largest resources, but none of these units contains hand-cobbable sodic feldspar.

Muscovite, although present in all units, is abundant only in the wall zone and the third and fourth intermediate zones. About one-half of the mica might be recovered by hand-cobbing, but the remainder could 
be obtained only by milling. The muscovite is almost entirely of scrap quality.

Small crystals of columbite are scattered throughout quartz-rich portions of the biotite-bearing hood, and larger crystals may have been recovered from the core. The grade of the entire pegmatite is only a fraction of a pound per ton.

\section{PEgMatite 11}

Pegmatite 11, a concordant quartz-rich pegmatite 6 feet thick, is exposed for 25 feet N. $80^{\circ} \mathrm{E}$. along its strike. It dips $80^{\circ} \mathrm{N}$. to vertical. It contains schist inclusions and scattered small biotite flakes where schist has been reworked. Perthite is a minor accessory mineral.

\section{PEgMatite 12}

Pegmatite 12 is an irregular, generally discordant pegmatite 100 feet long and from 5 to 10 feet thick. It strikes from west to northwest and dips $75^{\circ}$ to $80^{\circ}$ S. to SW. The deposit consists of a poorly developed wall zone of fine- to medium-grained quartz-perthiteplagioclase pegmatite surrounding a core of mediumgrained perthite-quartz pegmatite containing some graphic granite.

\section{PEGMATITE 13}

Pegmatite 13 is exposed over an area of 15 by 60 feet, and trends $\mathrm{N} .70^{\circ} \mathrm{W}$. It is a discordant body consisting of medium- to coarse-grained pegmatite containing virtually no exposed quartz and less than 1 percent muscovite. Perthite is the predominant mineral. Garnet is a minor accessory mineral. Potassic feldspar could be recovered by hand-cobbing. Further exploration should be done to determine the size of this pegmatite and the extent of the feldspar-rich unit.

PEgMatite 14

Pegmatite 14 is a small body that crops out in an area 20 by 40 feet. No contacts were visible, but the outcrop trends $\mathrm{N}$. $50^{\circ} \mathrm{W}$. and seems to be discordant. A small prospect pit for feldspar is 5 by 15 feet. The pegmatite has a wall zone of fine- to medium-grained plagioclase-quartz-perthite pegmatite and a core of medium- to coarse-grained perthite-quartz pegmatite. Possible products are milling-grade feldspar and a small quantity of potassic feldspar recoverable by hand-cobbing.

PEGMATITE 15

Pegmatite 15 is exposed in an outcrop as much as 20 feet wide and 125 feet long, and trends N. $65^{\circ} \mathrm{W}$. No contacts are visible, but it seems to be discordant. It is an unzoned fine- to medium-grained quartz-perthiteplagioclase pegmatite with accessory muscovite. Pos- sible products are milling-grade feldspar and scrap mica.

\section{PEGMATITE 16}

Pegmatite 16 is poorly exposed in an area 50 by 350 feet. It appears to strike approximately northwest, but the dip is unknown. It is a discordant unzoned body consisting of fine- to medium-grained plagioclasequartz-perthite pegmatite containing accessory muscovite, garnet, and black tourmaline. Possible products are milling-grade feldspar and scrap mica.

\section{PEGMATITE 17, GUINEA PROSPECTS}

The Guinea prospects are three small pits near the northwest end of a large discordant unzoned pegmatite. Its maximum exposed length is about 1,100 feet, and its width is as much as 200 feet. It forks at the southeast end. The average strike is $\mathrm{N} .30^{\circ} \mathrm{W}$., but the dip is unknown. The body consists of fine- to mediumgrained perthite-quartz-plagioclase pegmatite with muscovite and minor quantities of black tourmaline, garnet, biotite, beryl, and columbite. Two small beryl crystals each contain 12.7 percent $\mathrm{BeO}$. Most columbite plates are less than 1 inch across. Possible products are milling-grade feldspar and scrap mica.

\section{PEGMATITE 18}

Pegmatite 18 is exposed in the road bounding the east edge of the district. The length is unknown and the width is 5 to 8 feet. It is probably concordant, striking about $\mathrm{N} .40^{\circ} \mathrm{E}$. and dipping almost vertically. Zones are poorly developed. They include a wall zone of fine- to medium-grained plagioclase-perthite-quartz pegmatite, a thin intermediate zone of perthite-quartz pegmatite, and quartz pods representing segments of the core. A beryl crystal from the core contains 13.1 percent $\mathrm{BeO}$. The beryl content of the entire pegmatite is 0.14 percent.

\section{PEgMatite 19}

Pegmatite 19 is a poorly exposed discordant pegmatite, probably less than 20 feet thick, that trends N. $55^{\circ}$ W. for at least 190 feet. The dip is unknown. Although poorly zoned, it contains a wall zone of fine- to medium-grained plagioclase-perthite-quartz pegmatite and a core of quartz-perthite-plagioclase pegmatite. A fracture-controlled unit about 1 foot thick, striking $\mathrm{N}$. $70^{\circ} \mathrm{W}$., contains quartz and accessory muscovite. Beryl (13.1 percent $\mathrm{BeO}$ ) is a minor accessory mineral in the core and in the fracture-controlled body. The beryl content of the entire pegmatite is 0.015 percent. Possible products are milling-grade feldspar and scrap mica. 


\section{PEGMATITE 20}

Pegmatite 20 consists of three poorly exposed stringers ranging from 6 inches to 4 feet in thickness that crop out for less than 5 feet along their strikes. Two strike N. $60^{\circ} \mathrm{W}$. and the other strikes N. $60^{\circ} \mathrm{E}$.; the dips are vertical. The bodies consist of unzoned finegrained plagioclase-quartz-perthite pegmatite.

\section{PEgMatite 21}

Pegmatite 21, a concordant pegmatite 2 to 3 feet thick, is exposed for 15 feet along its strike, N. $70^{\circ} \mathrm{E}$. It contains a wall zone of fine-grained plagioclasequartz pegmatite and a core of fine- to medium-grained perthite-quartz-plagioclase pegmatite.

\section{PEGMATITE 22}

Pegmatite 22 is a concordant pegmatite $11 / 2$ feet thick and 20 feet long that strikes N. $60^{\circ}$ E. It consists of a thin border zone of very fine grained quartz-muscovite-plagioclase pegmatite and a core of fine- to medium-grained quartz-perthite pegmatite.

\section{PEGMATITE 23}

Pegmatite 23 is a curved, discordant pegmatite 65 feet long and 20 feet wide. It strikes about N. $70^{\circ} \mathrm{W}$.; but the dip is unknown. The pegmatite consists of a wall zone of fine- to medium-grained quartz-plagioclase pegmatite and a core of medium-grained quartz-plagioclase $\left(\mathrm{An}_{1-5}\right)$-muscovite pegmatite. Perthite is an accessory mineral in both zones, and muscovite is an accessory mineral in the wall zone. Beryl (13.0 percent $\mathrm{BeO}$ ) and columbite are minor accessory minerals in the core. The beryl content of the core is 0.6 percent. Possible products are milling-grade feldspar and scrap mica.

\section{PEGMATITE 24}

Pegmatite 24, a small, unzoned, discordant body, is 10 feet long and 3 feet thick. It strikes N. $80^{\circ} \mathrm{E}$., and the dip is vertical. It consists of plagioclase-quartz pegmatite, but also contains 15 percent of aplitic quartzplagioclase $\left(\mathrm{An}_{9-10}\right)$ aggregates scattered irregularly throughout the exposure.

\section{PEGMATITE 25}

Pegmatite 25 is represented by blocks and outcrops in an area 125 feet long and as much as 50 feet on the crest and sides of a low ridge. No contacts were seen, but the trend of the exposures is N. $60^{\circ} \mathrm{W}$., and the pegmatite probably is discordant. Two units are present: medium- to coarse-grained perthite-quartz pegmatite and fine- to medium-grained perthite-quartzplagioclase pegmatite containing small irregular masses of very fine grained aplitic material. Muscovite, beryl (13.1 percent $\mathrm{BeO}$ ), and columbite are minor accessory minerals in the coarser grained unit. Muscovite, biotite, and beryl (13.0 percent $\mathrm{BeO})$ are accessory minerals in the finer grained unit. Plagioclase $\left(\mathrm{An}_{2-3}\right)$ is an accessory mineral in the coarser unit. The beryl content of the entire pegmatite is 0.008 percent. Possible products are milling-grade feldspar and scrap mica.

\section{PEGMATITE 26}

Pegmatite 26 is discordant, 25 feet thick, and at least 130 feet long; it strikes N. $40^{\circ} \mathrm{W}$. and dips $60^{\circ} \mathrm{SW}$. It consists of a wall zone of fine- to medium-grained quartz-perthite-plagioclase pegmatite and segments of a discontinuous core of quartz-perthite-muscovite pegmatite containing accessory beryl (12.8 percent $\mathrm{BeO})$. The beryl content of the entire pegmatite is 0.05 percent. Possible products are feldspar, scrap mica, and beryl of milling grade. A small quantity of sheet mica could be recovered from the core.

\section{PEGMATITE 27}

Pegmatite 27 is an irregular body exposed on the face of a cliff. It is about 50 feet long and 2 to 4 feet thick and is concordant with bedding that strikes N. $45^{\circ} \mathrm{W}$. and dips $45^{\circ} \mathrm{NE}$. It is near the crest of a small anticline that plunges eastward at about $40^{\circ}$. It is an unzoned body that consists of irregular masses of quartz and medium-grained intergrowths of quartz and perthite. A few radiating groups of elongate black crystals of allanite (?) are in the quartz-perthite aggregates.

\section{PEGMATITE 28}

Pegmatite 28, also an irregular body, is exposed on a steep hillside. It strikes about N. $65^{\circ} \mathrm{W}$, dips $40^{\circ}$ NE., and has a maximum exposed thickness of 20 feet. It is concordant to the structure of the contorted wallrock. It is an unzoned body of fine- to medium-grained plagioclase-perthite-quartz pegmatite. Irregular patches of very fine grained aplitic material are exposed near the base of the hill. Garnet and white beryl (13.0 percent $\mathrm{BeO}$ ) are minor accessory minerals in and adjacent to the aplitic aggregates.

\section{PEGMATITE 29}

Pegmatite 29 is an outcrop or large boulder 10 by 25 feet in size that is in the floor of the stream valley below pegmatites 27 and 28 . No contacts are exposed. It consists chiefly of plagioclase-perthite-quartz pegmatite with accessory muscovite. A fracture-controlled quartz body 6 to 8 inches thick strikes N. $35^{\circ} \mathrm{W}$. and dips $40^{\circ}$ NE. Beryl (13.0 percent $\mathrm{BeO})$ is a minor accessory mineral of this unit. 


\section{Pegmatite 30}

Pegmatite 30 is 5 to 15 feet wide and crops out almost continuously for 200 feet N. $35^{\circ} \mathrm{W}$. No contacts are exposed, but the trend is discordant to foliation in the nearest wallrock exposures. Several schist inclusions are present. It is an unzoned body of fine- to medium-grained plagioclase-quartz-perthite pegmatite containing minor accessory muscovite. Possible products are milling-grade feldspar and scrap mica.

\section{PEGMATITE 31}

Pegmatite 31 is a concordant body at least 20 feet long and as much as 8 feet wide. It strikes N. $45^{\circ} \mathrm{E}$. and dips steeply northwestward. The pegmatite consists of a thin border zone of very fine grained perthitequartz-muscovite pegmatite, a wall zone of the same composition but fine to medium grained, and a core of coarse-grained perthite-quartz pegmatite. Beryl (13.1 percent $\mathrm{BeO}$ ) is a minor accessory mineral in the wall zone.

\section{PEgMatite 32}

Pegmatite 32 has been stripped for a length of at least 45 feet, and a width of 8 feet. It is discordant; no contacts were seen, but the trend of exposures is $\mathrm{N}$. $5^{\circ}$ E. Poorly developed units include a wall zone of fine-grained quartz-plagioclase-muscovite pegmatite and a core of medium-grained quartz-perthite pegmatite. Beryl (13.1 to 13.5 percent $\mathrm{BeO}$ ) is a minor accessory mineral in the core and wall zone.

\section{PEGMATITE 38}

Pegmatite 33 is discordant, unzoned, at least 125 feet long, and as much at 25 feet thick. It strikes N. $65^{\circ}$ W. and dips steeply southwestward. The rock is medium- to coarse-grained quartz-perthite-plagioclase pegmatite containing muscovite and minor quantities of beryl. Possible products are milling-grade feldspar and scrap mica.

\section{PEgMatite 34}

Pegmatite 34, a very small irregular discordant body, is 2 feet long and 6 inches thick. It strikes east, dips $70^{\circ} \mathrm{N}$., and consists principally of white perthite.

\section{PEGMATITE 35}

Pegmatite 35 is a discordant body 25 feet thick, exposed for 20 feet $\mathrm{N}$. $45^{\circ} \mathrm{W}$. along its strike. It dips steeply northeastward. There is no apparent zoning although graphic granite is abundant for 8 feet inward from the footwall; otherwise the body is quartz-perthite-muscovite pegmatite. Beryl and garnet are minor accessory minerals.

\section{PEGMATITE 36}

Pegmatite 36 is represented by boulders and small outcrops trending $\mathrm{N} .65^{\circ} \mathrm{W}$. for 100 feet. No contacts were seen, but the pegmatite probably is discordant. It is an unzoned fine- to medium-grained quartz-perthiteplagioclase pegmatite with accessory muscovite. Possible products are milling-grade feldspar and scrap mica.

\section{PEGMATITE 37}

Pegmatite 37 is 3.15 miles S. $44^{\circ} \mathrm{W}$. of Raymond village. Although it never has been mined, the Whitehall Co., Inc., stripped part of the overburden in 1947 while prospecting for feldspar in the Raymond district.

As mapped, the pegmatite is roughly rectangular ( $\mathrm{pl}$. 9 ). It is about 350 feet long and has an average width of 170 feet. Contacts with quartz-mica schist are very poorly exposed at two places. Near the northwest corner of the pegmatite, the strike is north, and the dip ranges from $25^{\circ}$ to $60^{\circ} \mathrm{E}$. The pegmatite seems to be concordant on the northwest and southeast sides and discordant elsewhere. Although pegmatite 38 is only 25 feet from the southeast corner of pegmatite 37 , there is no evidence that the two are connected. A plunge of $15^{\circ}$ to $20^{\circ} \mathrm{NE}$. is suggested by the structure of the intermediate zone around the core and by the direction and angle of plunge of minor folds in the wallrock.

The pegmatite is poorly exposed except in those places where the overburden has recently been removed during prospecting. Four units, of which three have been mapped (pl. 9) can be distinguished in these exposures. Possibly the present land surface truncates only the upper part of outer units of the pegmatite, and more zones are present at depth. The border zone is very fine grained quartz-muscovite-plagioclase pegmatite present at the few places where the contact is exposed. It is about one-half inch thick, and thus cannot be shown on plate 9 .

The wall zone consists of fine- to medium-grained plagioclase-quartz-perthite pegmatite with accessory muscovite, garnet, and minor accessory apatite and biotite. The average composition is 40 percent plagioclase, 30 percent quartz, 25 percent perthite, and 5 percent accessory minerals. Plagioclase and quartz-muscovite intergrowths form a matrix for the coarser grained perthite crystals. The average thickness of the zone is unknown. The broad areas of wall zone shown on plate 9 may be a thin cover above inner zones.

The intermediate zone is a discontinuous unit of fineto medium-grained quartz-perthite-plagioclase pegmatite exposed around the northeast end of the core. This unit is less than 10 feet thick and pinches out southwestward. The average composition is 40 percent quartz, 30 percent perthite, 25 percent plagioclase, and 5 percent accessory minerals. It contains the same 
accessory minerals as the wall zone, and in addition, beryl. Mineral measurements indicate a beryl content of 0.04 percent, but beryl is more abundant immediately adjacent to the core.

The core is medium- to coarse-grained perthitequartz-plagioclase pegmatite in which graphic granite is abundant, especially in the exposure near the northwest corner of the pegmatite. The average composition is 55 percent perthite, 30 percent quartz, 10 percent plagioclase, and 5 percent accessory minerals. The accessory minerals are muscovite, garnet, cleavelandite, and beryl. The beryl consisted of one crystal, found near the intermediate zone. The exposures of the core shown on plate 9 are probably parts of a single unit that has been only partly uncovered by erosion. The core may be nearer the footwall than the hanging wall.

Beryl occurs as small crystals in the intermediate zone, and is most abundant adjacent to the core. Mineral measurements show that the grade of this zone is 0.04 percent, but these crystals are too small to recover by hand-cobbing. One crystal 5 by 7 inches is in the core adjacent to the intermediate zone.

Pegmatite 37 is one of the few in the Raymond district that offers possibilities for the recovery of potassic feldspar by hand-cobbing. Coarse-grained perthite in the core is associated with only minor amounts of garnet and graphic quartz. The entire pegmatite has a composition and size that would make it a logical source of millfeed if a mill were established in the area.

Plagioclase is most abundant in the wall zone, and would be recoverable only with perthite through milling that would separate feldspar from the other minerals.

Muscovite is most abundant in the wall and intermediate zones, although it is also an accessory mineral in the core. Almost all books are less than 1 inch in diameter, and could be recovered only by milling methods. All the mica is of scrap quality.

\section{PEgMatite 38}

Pegmatite 38 is represented by outcrops and blocks extending N. $30^{\circ} \mathrm{W}$. for 750 feet. The pegmatite is at least 60 feet thick, and dips $45^{\circ} \mathrm{NE}$; it is generally concordant. The rock is fine- to medium-grained quartz-perthite-plagioclase pegmatite containing accessory muscovite. Possible products are milling-grade feldspar and scrap mica.

\section{PEGMATITE 39}

Pegmatite 39 is a generally concordant unzoned body 50 feet thick and 150 feet long that strikes N. $40^{\circ}$ W. and probably dips northeastward. It has fine- to medium-grained quartz-perthite-plagioclase pegmatite with accessory muscovite, as well as minor amounts of beryl and garnet. The beryl content of the entire pegmatite is 0.0035 percent. Crystals associated with irregular quartz bodies contain 12.8 to 12.85 percent $\mathrm{BeO}$; other crystals contain 13.0 to 13.2 percent $\mathrm{BeO}$. Possible products are milling-grade feldspar and scrap mica.

PEgMatiTe 40

Pegmatite 40 is marked by outcrops and blocks, extending N. $20^{\circ} \mathrm{W}$. for 800 feet, that are probably parts of a single discordant body. The maximum width is less than 100 feet. The dip ranges from $70^{\circ} \mathrm{NE}$. near the northwest end to $10^{\circ} \mathrm{E}$. near the center of the pegmatite. The rock is fine- to medium-grained quartz-plagioclase-perthite pegmatite containing accessory muscovite. Green (12.9 percent $\mathrm{BeO})$ and white (13.1 to 13.2 percent $\mathrm{BeO}$ ) beryl are minor accessory minerals. The beryl content of the entire pegmatite is approximately 0.0006 percent. Possible products are milling-grade feldspar and scrap mica.

\section{PEgmatite 41}

Pegmatite 41 is represented by boulders and small outcrops extending 35 feet $\mathrm{N}$. $35^{\circ} \mathrm{W}$. The pegmatite probably is discordant, and dips northeastward at a low angle. It has fine- to medium-grained plagioclasequartz-muscovite pegmatite that is cut by fracturecontrolled quartz bodies 2 inches thick.

\section{PEGMATITE 42}

Pegmatite 42 is a discordant pegmatite 700 feet long and as much as 100 feet thick; it has a strike ranging from almost north at the southeast end to northwest at the northwest end. The average dip is $80^{\circ} \mathrm{SW}$. Two small feldspar prospect pits were opened by the Whitehall Co., Inc., in the bulbous northwest end. The zones, observed only near the pits, include a wall zone, 5 to 15 feet thick, of fine- to medium-grained plagioclase-quartz-perthite pegmatite that thickens to the southeast until it is the only unit present; an intermediate zone, 6 to 25 feet thick, of medium-grained plagioclase-perthite-quartz-muscovite and biotite pegmatite present only along the footwall side; a coremargin zone, 2 to 3 feet thick, of medium-grained plagioclase-quartz-perthite-muscovite pegmatite intermittently exposed between the first intermediate zone and the core; and a core of perthite-quartz-plagioclase pegmatite. Small parts of the core contain graphic granite. Muscovite occurs in all units. Beryl is a minor accessory mineral in the first intermediate zone, which has a beryl content of 0.06 percent. A specimen of stained beryl from this unit contains 12.9 percent $\mathrm{BeO}$, and another of fresh green beryl contains 13.1 
percent $\mathrm{BeO}$. Near the prospect pits, possible products are hand-cobbed perthite and mica of milling grade.

\section{PEGMATITE 48}

Pegmatite 43 is at a locality that contains two concordant pegmatites 5 to 6 inches thick exposed for 8 to 12 feet N. $65^{\circ}$ E. along their strike. Both are fine grained. One is an unzoned quartz-plagioclase-muscovite pegmatite with accessory beryl (13.9 percent $\mathrm{BeO})$; the other has a 2 -inch zone of perthite and quartz along the footwall, a 2-inch core of quartzmuscovite pegmatite, and a 2 -inch zone of quartz-muscovite-plagioclase pegmatite along the hanging wall.

\section{PEgMatite 44}

Pegmatite 44 is concordant, 375 feet long, and is exposed over a width of 25 feet. The pegmatite strikes N. $60^{\circ}$ E. and dips $35^{\circ} \mathrm{NW}$. It consists of a wall zone of fine- to medium-grained quartz-perthiteplagioclase pegmatite and a core of medium-grained material of similar composition. Muscovite is an accessory mineral in both units, and beryl (11.6 percent $\mathrm{BeO}$ ) is a minor accessory mineral in the wall zone. A small prospect pit was opened by the Whitehall Co., Inc. Possible products are milling-grade feldspar and scrap mica.

\section{PEGMATITE 45, SMITH NO. 2 PROSPECT}

Pegmatite 45 is a discordant body that crops out intermittently for 1,200 feet along a trend of N. $60^{\circ} \mathrm{W}$. Although the contacts are poorly exposed, the maximum thickness probably is about 75 feet. The dip is $80^{\circ} \mathrm{SW}$. Two small prospect pits were opened for feldspar near the northwest end by the Whitehall Co., Inc. In these pits the pegmatite consists of a wall zone of fine- to medium-grained quartz-plagioclaseperthite-muscovite pegmatite with minor accessory beryl (11.6 percent $\mathrm{BeO}$ ), and a core of perthitecleavelandite-muscovite pegmatite with accessory garnet and pyrite. The core locally extends to the wall of the pegmatite. Zoning is not distinguishable southeast of the pits, where the pegmatite consists of quartz, perthite, and plagioclase. Possible products are handcobbed perthite containing pyrite and garnet impurities, and feldspar and scrap mica of milling grade.

\section{PEGMATITE 46}

Pegmatite 46 is marked by scattered pegmatite blocks and outcrops extending 130 feet N. $5^{\circ} \mathrm{W}$. The exposure ranges from 5 to 25 feet in width, and the dip is unknown. This is a discordant pegmatite consisting of 2 units of about equal size; 1 contains fineto medium-grained quartz-plagioclase-perthite pegmatite and the other contains medium-grained perthite- quartz pegmatite. Either of the two units may be adjacent to wallrock. Accessory minerals include muscovite, minor amounts of beryl (13.0 percent $\mathrm{BeO})$, and black tourmaline. Albite $\left(\mathrm{An}_{9-10}\right)$ is an accessory mineral in perthite-quartz pegmatite. The beryl content of the quartz-plagioclase-perthite pegmatite is 0.038 percent. Possible products are milling-grade feldspar and scrap mica.

\section{PEGMATITE 47}

Pegmatite 47 is represented by scattered blocks and outcrops extending 125 feet N. $40^{\circ}$ E. The maximum exposed width is 4 feet. No contacts were seen, but the pegmatite seems to be concordant. It contains a wall zone, 1 foot thick, of fine-grained quartz-muscovite-plagioclase pegmatite and an inner unit of perthiteplagioclase $\left(\mathrm{An}_{2-4}\right)$-quartz pegmatite. White beryl $(13.2$ percent $\mathrm{BeO})$ is a minor accessory mineral in the wall zone.

\section{PEGMATITE 48}

Pegmatite 48 crops out in the road, strikes N. $65^{\circ}$ E., dips $80^{\circ} \mathrm{SE}$., and is concordant. It is 3 feet thick and at least 25 feet long. It contains a 2 -inch border zone of very fine grained plagioclase-quartz-muscovite pegmatite, a wall zone of fine-grained quartz-plagioclase-muscovite pegmatite, and a core of very fine grained sugary-textured plagioclase $\left(\mathrm{An}_{6}\right)$-quartz pegmatite. There are streaks of very fine grained garnet in the sugary-textured rock. Beryl (13.4 percent $\mathrm{BeO}$ ) is a minor accessory mineral in the wall zone.

\section{PEGMATITE 49, SMTTH NO. 3 PROSPECT}

The Smith No. 3 feldspar prospect is 3.3 miles $\mathrm{S}$. $50^{\circ} \mathrm{W}$. of Raymond village. In 1947, the Whitehall Co., Inc. removed the overburden from the pegmatite and opened a small prospect pit to test for feldspar.

The pegmatite consists of three connected podlike bodies (pl. 10) that trend eastward for 200 feet. These irregular bodies range in size from about 20 by 50 to 50 by 50 feet. At the northwest corner, tabular apophyses extend northeastward and southwestward. The southwest apophysis, ranging from $11 / 2$ to 5 feet in thickness, can be traced for at least 120 feet S. $70^{\circ}$ W. The northeast apophysis shown on plate 10 extends for 170 feet N. $55^{\circ}$ E. and can be traced for an additional 350 feet $\mathrm{N}$. $70^{\circ} \mathrm{E}$. There is no evidence that these tabular bodies are of different age than the main pegmatite, and they seem to have been injected along bedding planes of the wallrock at the same time that the generally discordant main pegmatite was injected. The apophyses dip steeply southeastward; the contacts of the main pegmatite dip either vertically or steeply 
away from the center, indicating enlargement of the pegmatite at depth.

A thin border zone, a wall zone, and a discontinuous core can be distinguished in this pegmatite. The border zone consists of very fine grained quartz-muscoviteplagioclase pegmatite. The maximum thickness is 12 inches, but it commonly is less than 1 inch thick, and thus is too thin to be shown on plate 10.

The wall zone is fine-grained plagioclase-quartzperthite pegmatite. The average composition of this unit is $\mathbf{5 5}$ percent plagioclase, 30 percent quartz, 10 percent perthite, and 5 percent accessory minerals including muscovite, garnet, biotite, and beryl.

The core is medium- to coarse-grained perthitequartz-plagioclase pegmatite. Cleavelandite and muscovite are accessory minerals; garnet and beryl are minor accessory minerals. Small masses of cleavelandite-quartz-muscovite-perthite pegmatite occurs in the unit, but these are probably local variations in the composition of the core rather than a separate unit. Fine-grained graphic granite is particularly abundant in the eastern part of the main body of pegmatite.

Mineral measurements indicate that the beryl content of the entire pegmatite is about 0.0036 percent. Most of the crystals are too small to be recovered by hand-cobbing.

Perhaps 30 percent of the perthite in the core could be recovered by hand-cobbing, but the only economically important production would come through milling the entire pegmatite. Plagioclase, because of its small grain size, could be recovered only by mechanical means, and in most present-day processes would be recovered with the perthite. The small size of the pegmatite does not favor its use as millfeed except in combination with other pegmatites in the area.

No muscovite of sheet quality was observed. Scrap mica forms only about 2 percent of the entire pegmatite.

\section{PEGMatite 50}

Pegmatite 50 is discordant, 4 feet thick, and exposed for 20 feet along its strike of N. $40^{\circ} \mathrm{W}$.; it dips $80^{\circ} \mathrm{SW}$. It consists of a hanging-wall unit of fine-grained plagioclase-quartz-muscovite pegmatite, a core of coarsegrained quartz-perthite pegmatite, and a footwall unit of fine-grained plagioclase-quartz-perthite pegmatite. Muscovite is an accessory mineral, and beryl is a minor accessory mineral in all units. Beryl from the hangingwall unit contains 13.4 percent $\mathrm{BeO}$.

\section{PEGMATITE 51}

Pegmatite 51 is represented by scattered pegmatite blocks extending 80 feet N. $50^{\circ} \mathrm{W}$.; there are no definite outcrops. The thickness and dip are unknown, but the pegmatite is probably discordant. Possible zones con- sist of a thin border unit of very fine grained muscovitequartz-plagioclase pegmatite and a core of fine-grained quartz-plagioclase pegmatite containing accessory muscovite and perthite. Beryl (13.4 percent $\mathrm{BeO}$ ) is a minor accessory mineral in both units; the beryl content of the entire pegmatite is 0.02 percent.

\section{PEGMATITE 52}

Pegmatite 52 is a large poorly exposed concordant pegmatite 1,000 feet long and possibly 200 feet thick. The average strike is about N. $60^{\circ} \mathrm{E}$., but the dip is unknown. The pegmatite is poorly zoned, and consists mostly of fine- to medium-grained quartz, plagioclase, and perthite, although there are small masses of coarsegrained perthite and quartz. Muscovite is an accessory mineral in the finer grained unit, and columbite is a minor accessory mineral of the coarser grained unit. Possible products are hand-cobbable perthite, and feldspar and scrap mica of milling grade.

\section{PEGMATITE 53}

Pegmatite 53 crops out along a trend of N. $70^{\circ}$ E. No contacts were exposed, but its dimensions may be as much as 400 feet by 100 feet. The dip is unknown, and the trend of the pegmatite suggests that it is probably concordant. It consists of quartz-plagioclase-perthite pegmatite with accessory muscovite. The plagioclase is partly cleavelandite $\left(\mathrm{An}_{0-2}\right)$.

\section{PEGMATITE 54}

Pegmatite 54, a discordant pegmatite at least 60 feet long and 20 feet thick, strikes N. $15^{\circ}$ E. and dips $75^{\circ}$ E. It consists of a wall zone of fine- to medium-grained plagioclase-quartz-perthite pegmatite and a thin core, 3 to 7 feet thick, of medium- to coarse-grained perthitequartz pegmatite. Muscovite and beryl are accessory minerals. A fracture-controlled body 4 inches thick cuts the wall zone. This body contains quartz, muscovite, beryl, and minor amounts of plagioclase $\left(\mathrm{An}_{1_{-2}}\right)$. The beryl content of the entire pegmatite is 0.02 percent. The beryl in the wall zone has 13.2 percent $\mathrm{BeO}$; that in the fracture-controlled body contains 13.1 percent $\mathrm{BeO}$. Possible products are milling-grade feldspar and scrap mica.

\section{PEGMATITE 55}

The trend of pegmatite 55 is indicated by outcrops and blocks extending N. $40^{\circ} \mathrm{W}$. for 100 feet. The pegmatite is discordant and unzoned. The width of exposure ranges from 2 to 20 feet, and the dip of the pegmatite is $80^{\circ} \mathrm{NE}$. The rock is fine- to medium-grained quartz-plagioclase $\left(\mathrm{An}_{5-6}\right)$-perthite pegmatite with accessory muscovite and beryl. Beryl (13.0 percent $\mathrm{BeO})$ 
content of the entire pegmatite is 0.135 percent. Possible products are milling-grade feldspar and scrap mica.

PEGMATITE 66, BLAKE (MAFERA) MINE

The Blake feldspar mine (pl. 11) is 3.6 miles $\mathrm{S} .49^{\circ}$ W. of Raymond village. It was opened in 1945 and was operated by the Whitehall Co., Inc., until 1947 when it was closed reportedly because of litigation concerning ownership. It was worked from an opencut 100 feet long, 15 to 60 feet wide, and as much as 35 feet deep at the north end. The cut is filled with water to an average depth of 15 feet.

The pegmatite is about 130 feet long and as much as 70 feet thick. The average strike is N. $30^{\circ} \mathrm{E}$., which is roughly concordant with the bedding of the enclosing mica-quartz schist, and the dip is steep to the northwest. The plunge of the pegmatite might be about $45^{\circ} \mathrm{SW}$., but no accurate measurements of the angle and direction of plunge could be made. At the southwest corner of the opencut, an offshoot from the main body can be traced for 50 feet $\mathrm{N}$. $70^{\circ} \mathrm{W}$. It is as much as 15 feet thick.

The border zone is very fine grained quartz-muscovite pegmatite with accessory plagioclase, garnet, and beryl. This unit is not everywhere present at the contact and is nowhere more than 1 inch thick.

The wall zone is fine- to medium-grained quartzmuscovite-plagioclase pegmatite, and is exposed only at the south end of the opencut. The average composition is 40 percent quartz, 30 percent muscovite, 25 percent plagioclase, and 5 percent accessory minerals. It is 2 feet thick where exposed.

The first intermediate zone consists of fine- to medium-grained quartz-plagioclase pegmatite. In some places it is adjacent to the schist contact, and the outer two zones are absent. The average composition is 65 percent quartz, 30 percent plagioclase, and 5 percent accessory perthite and muscovite and minor accessory garnet, beryl, and apatite. The pegmatite offshoot at the southwest corner of the opencut is composed of a variety of this zone in which plagioclase is nearly as abundant as quartz, and perthite forms more than 5 percent of the rock.

The largest unit is medium- to coarse-grained perthite-quartz-plagioclase pegmatite, from which most of the perthite was mined. The average composition is 55 percent perthite, 30 percent quartz, 10 percent plagioclase, and 5 percent accessory minerals. The accessory minerals are chiefly muscovite and cleavelandite, but also include garnet and apatite. Columbite and beryl are reported to have been recovered from this unit.

The core-margin unit, or third intermediate zone, consists of medium-grained plagioclase-muscovitequartz-perthite pegmatite. It is exposed only on the east side of a small segment of the quartz-perthite pegmatite of the core, where it is less than 2 feet thick. The average composition is 40 percent plagioclase, 30 percent muscovite, 15 percent quartz, 10 percent perthite, and 5 percent accessory minerals. About one-half the plagioclase is cleavelandite.

Small discontinuous segments of the coarse-grained quartz-perthite core are exposed. Larger segments may be in the floor of the water-filled opencut. The average composition of the core is 70 percent quartz and 30 percent perthite. Minor accessory minerals include sphalerite, chalcopyrite, covellite, and löllingite. Columbite has been reported from this unit.

Beryl is present in the first intermediate and border zones. Mineral measurements made on the east wall of the opencut indicate a beryl content of 0.148 percent in the first intermediate zone, and this is in close accord with recovery data. Four mineral measurements, however, randomly selected on the surface of the dump, indicated a beryl content of 0.37 percent. This increase was partly caused by the residual concentration of beryl in the dump material from which large tonnages of feldspar were removed, and perhaps partly by carelessness in cobbing. The largest crystal reported by the operator was 2 by 4 feet, but the average size of the crystals measured was 2 by 4 inches. With careful hand-cobbing, 75 percent of the beryl might be recovered.

The largest reserves of potassic feldspar are in the second intermediate zone and core, the same units that produced this mineral in the past. The size of perthite crystals in these units is large enough to permit the recovery of at least 60 percent by hand-cobbing.

The Blake pegmatite is one of the few in the Raymond district that could yield small amounts of sheet mica. The wall zone at the south end of the opencut contains an estimated 30 percent muscovite of which perhaps 1 percent is of sheet size and quality. The extent of this unit downdip is unknown, and it is exposed along its strike for only 15 feet. The muscovite is greenish-rum colored and clear, but most of the books are badly fractured. The largest sheets that could be trimmed from books observed in this unit were about $11 / 2$ by 2 inches. A few muscovite books from the core-margin zone also may contain small sheets of flat mica. Scrap mica could be recovered by hand-cobbing only from the wall and core-margin zones. More than a third of the total muscovite in these units could be recovered by this method. Milling of the entire pegmatite, which has an estimated muscovite content of 2 percent, would permit a much larger recovery.

Columbite was reported by workmen to have occurred throughout the pegmatite and it is probable that 
most was recovered from the inner units. The average size of the plates seen was 1 inch long, one-half inch wide, and one-fourth inch thick, but larger crystals have been reported by the former operator. The pegmatite is estimated to contain about one-third of a pound of columbite per ton of rock.

\section{PEgMatite 57, IANE PROSPECT}

The Lane prospect contains two small pits opened by the Whitehall Co., Inc., for feldspar near the southeast end of a discordant pegmatite 750 feet long and as much as 50 feet thick. The average strike is $\mathrm{N}$. $55^{\circ}$ $\mathrm{W}$., and the dip is $80^{\circ} \mathrm{SW}$. The thicker southeast end consists of a wall zone of fine-to medium-grained plagioclase-quartz-perthite-muscovite pegmatite, a coremargin zone of medium- to coarse-grained perthitequartz-muscovite pegmatite, and a core of quartz pegmatite. Minor accessory minerals are biotite, beryl, garnet, black tourmaline, and apatite. Northwestward from the prospect pits, the pegmatite thins and has only a wall zone of quartz-plagioclase $\left(\mathrm{An}_{4-5}\right)$-perthitemuscovite pegmatite ranging from 4 to 5 feet in thickness and a core of quartz-perthite pegmatite. The beryl content is 0.03 percent in the southeastern part of the pegmatite; the mineral is commonly stained and has a $\mathrm{BeO}$ content of 12.5 to 12.8 percent. In the northwestern part, beryl is less abundant $(0.014$ percent) and has a $\mathrm{BeO}$ content ranging from 12.8 percent in a specimen from midway between the ends of the pegmatite, to 13.2 percent in a specimen from the northwest end. Possible products are hand-cobbed perthite and milling-grade feldspar, scrap mica, and beryl.

\section{PEgMatiTe 58}

Pegmatite 58, a poorly exposed body, is at least 140 feet long and 20 feet thick. It strikes N. $55^{\circ} \mathrm{W}$., dips $75^{\circ} \mathrm{SW}$, and is discordant. It constits of fineto medium-grained quartz-plagioclase $\left(\mathrm{An}_{8-9}\right)$-perthite pegmatite. Muscovite and cleavelandite $\left(\mathrm{An}_{2-3}\right)$ are the chief accessory minerals; biotite, beryl (12.9-13.0 percent $\mathrm{BeO}$ ), and garnet are minor accessory minerals. The beryl content of the entire pegmatite is 0.01 percent. Possible products are milling-grade feldspar and scrap mica.

\section{PEGMATITE 59}

Pegmatite 59, from 6 to 12 inches thick and 10 feet long, strikes N. $60^{\circ} \mathrm{E}$. parallel to foliation of the wallrock. It dips steeply northwestward across the dip of the foliation. It is an unzoned quartz-plagioclase pegmatite with accessory muscovite.

\section{PEGMATITE 60}

Pegmatite 60, a concordant pegmatite from 2 to $31 / 2$ feet thick, is exposed intermittently for 40 feet along 681919-62_4 a strike of $\mathrm{N} .65^{\circ} \mathrm{E}$; it dips $70^{\circ} \mathrm{NW}$. It contains a wall zone of fine-grained muscovite-quartz-plagioclase $\left(\mathrm{An}_{15}\right)$ pegmatite, a core-margin zone of mediumgrained plagioclase-quartz-perthite pegmatite, and a core of massive quartz. Beryl is a minor accessory mineral in the wall zone (13.1 percent $\mathrm{BeO})$ and in the core-margin zone.

\section{PEGMATITE 61}

Pegmatite 61 is unzoned and small, not more than 2 feet thick. It is very irregular and both concordant and locally discordant to the foliation of the enclosing wallrock. The dip is probably vertical. It is quartzplagioclase-perthite pegmatite with accessory muscovite and beryl.

\section{PEGMATITE 62, WELCH MINE}

The Welch feldspar mine is 3.6 miles S. $45^{\circ} \mathrm{W}$. of Raymond village. It was operated intermittently from 1943 until 1947; the most recent work was done by the Whitehall Co., Inc. The overburden has been stripped from much of the pegmatite. The larger working is an opencut 100 feet long, as much as 40 feet wide and 20 feet deep, that was driven northeastward into the pegmatite. A smaller opencut was started near the northwest corner of the pegmatite.

The contact between pegmatite and wallrock is nowhere exposed, although the enclosing rocks are probably no more than a few feet beyond the pegmatite outcrops (pl. 12). The pegmatite is exposed for 320 feet N. $35^{\circ} \mathrm{W}$. and has a maximum exposed width of 85 feet. The strike is probably nearly the same as the trend of the outcrops, and the dip appears to be $60^{\circ}$ SW. The plunge of the pegmatite is unknown, but the alinement of quartz masses, probably discontinuous segments of the core, indicates a plunge of $50^{\circ} \mathrm{S}$.

The southeastern half of the Welch pegmatite consists of well-developed zones; the northwestern half, however, contains only units that seem to be of replacement origin, and well-arranged zones are not present. The change between the two halves of the pegmatite is at or near the fault exposed in the opencut. The fault plane strikes N. $60^{\circ}$ E. and dips $50^{\circ} \mathrm{SE}$., and although its displacement is not known, it is not necessarily large. The fault gouge may have acted as an impermeable barrier that permitted alteration of pre-existing pegmatite northwest of the fault by later sodic-rich pegmatite solutions. If this were true, the fault must be later than the consolidation of the zoned pegmatite but earlier than the last stage of pegmatitic activity in the whole body.

In the southeast half of the pegmatite the outer unit, probably the wall zone although no contacts with wallrock were seen, is fine- to medium-grained plagioclase- 
quartz-perthite pegmatite. The average composition is 35 percent plagioclase, 30 percent quartz, 30 percent perthite, and 5 percent accessory minerals. Muscovite is a common accessory mineral, and garnet and beryl are minor accessory minerals. Plagioclase and quartz are finer grained than the perthite, and are interstitial to it. The unit thickens at the southeast end of the pegmatite exposure but thins northwestward.

The first intermediate zone is characterized by aggregates of very fine grained granitic material. The average composition is 30 percent perthite, 20 percent plagioclase, 15 percent quartz, 30 percent granitic material, and 5 percent accessory minerals. Muscovite and cleavelandite are the chief accessory minerals, and garnet, apatite, and beryl are minor accessory minerals. Graphic granite is more abundant in this unit than elsewhere in the pegmatite.

Pods of granitic materials, consisting of plagioclase, quartz, perthite, and minor muscovite and garnet, are scattered at random throughout the zone. Grains are commonly less than one-quarter inch in diameter, but some of the perthite is 1 inch long. The very fine grained areas grade into the coarser grained perthiteplagioclase-quartz pegmatite. The granitic material has corroded large perthite crystals, and single cleavage faces of perthite can be traced into the finer grained material. The gradation in texture between fine- and coarse-grained parts of the zone, its regular occurrence in the zonal sequence, and its similarity in extent to other zones indicate that the very fine grained material is virtually contemporaneous with other material of the zone. Therefore it has corroded only those crystals that had developed in the earliest consolidation stages of the unit.

The second intermediate zone is a medium- to coarsegrained perthite-quartz-plagioclase pegmatite that has been the major source of potassic feldspar recovered at the mine. The average composition is 50 percent perthite, 30 pereent quartz, 15 percent plagioclase, and 5 percent accessory minerals. Muscovite and cleavelandite are the most abundant accessory minerals, and garnet, beryl, columbite, and apatite are minor accessory minerals.

The third intermediate zone consists of fine- to medium-grained quartz-plagioclase pegmatite. The average composition is 65 percent quartz, 30 percent plagioclase, and about 5 percent accessory minerals. Muscovite and beryl are the major and minor accessory minerals, respectively. About half of the plagioclase is cleavelandite. This unit crops out near the center of the pegmatite southeast of the fault and in the main opencut.
The core is fine- to coarse-grained perthite-quartzmuscovite-cleavelandite pegmatite. The average composition is 40 percent perthite, 35 percent quartz, 15 percent muscovite, and 10 percent cleavelandite, but in any single exposure of the unit, one or more of these minerals may be absent. The muscovite is fine grained, yellowish green, and is the typical "burr" mica often associated with cleavelandite. The core is discontinuous, consisting of several segments near the center of the pegmatite.

The replaced northwest part of the pegmatite consists mostly of medium- to coarse-grained perthiteplagioclase-muscovite pegmatite with accessory garnet and pyrite, chalcopyrite, sphalerite, and other sulfides. The average composition is 45 percent perthite, 40 percent plagioclase, 10 percent muscovite, and 5 percent accessory minerals. Locally the muscovite content increases to 40 percent of the unit. Although in most places the fault acts as a sharply defined contact with zoned pegmatite, a few small muscovite-rich pods occur southeast of the fault. These appear to have been superimposed on the normal pegmatite of the zones and may be at places where solutions passed through the generally impermeable barrier along the fault. The muscovite books and flakes northwest of the fault are commonly less than one-half inch in maximum dimension and are green, yellowish-green, or greenishrum. In the pegmatite especially rich in muscovite, the books are larger and mostly greenish-rum. The small pods southeast of the fault contain fine-grained yellowish-green flakes and very small books of muscovite. The feldspars of the unit are commonly stained by iron oxide, and the plagioclase characteristically is vuggy.

The unit northwest of the fault is characterized by an extremely low percentage of quartz, probably less than 1 percent of the rock. Most quartz occurs as small crystals lining vugs surrounded by feldspar, and only rarely does it occur in irregular intergrowths with plagioclase typical of the zones. Many of the vugs in the plagioclase appear to have the characteristic shape and size of quartz in the pegmatite of the second intermediate zone southeast of the fault. In one place, quartz in vugs in perthite has the same arrangement and size as the quartz in typical graphic granite. These features suggest that quartz has been removed by solutions acting on perthite-quartz-plagioclase pegmatite of the second intermediate zone.

The second unit distinguished northwest of the fault is similar in texture and composition to the one described above except that muscovite forms less than 5 percent of the unit. 
Thus the textures and the different mineralogy suggest that the northwest part of this pegmatite consists of material formed by replacement of previously solidified zones. The subdivision into two units may reflect differences in the composition of zones before the replacement stage. It is not clear whether the fault is prereplacement, and thus was a barrier to the fluids, or postreplacement, and caused juxtaposition of unlike rocks.

Beryl is present only in the zoned pegmatite southeast of the fault, where it has been found in all zones. Mineral measurements indicate the beryl content of this part of the pegmatite to be about 0.04 percent. The third intermediate zone contains the largest beryl concentrations. Measurements made at random on the surface of the dumps indicate a grade of 0.03 percent. The average crystals have an exposed surface area of 3.3 square inches, and 50 percent probably could be recovered by hand cobbing.

Potassic feldspar resources are in all zones southeast of the fault, except the third intermediate zone. The average perthite content of this part of the pegmatite is about 40 percent, and recovery by hand-cobbing is possible in both the second intermediate zone and the core. Northwest of the fault, the average perthite content is about 50 percent, and three-fourths of it could be recovered by hand-cobbing. Much of this feldspar is stained by iron oxides.

Sodic feldspar comprises 20 percent of the pegmatite southeast of the fault and 45 percent northwest of it. Southeast of the fault the grain size is too small to permit recovery by hand-cobbing, and only an estimated 25 percent of the total sodic feldspar northwest of the fault could be recovered by this method. This feldspar is stained by iron oxides. Recovery of sodic feldspar by milling would be much greater than by hand methods, but the product would be combined with potassic feldspar.

Muscovite in the Welch deposit could be used for scrap purposes, but only a very few small books contain material of sheet quality. About 75 percent of the muscovite in the richest areas northwest of the fault could be recovered by hand-cobbing, but in other places recovery by this method would be very low. The average grade of the entire pegmatite northwest of the fault is estimated to be 5 percent; southeast of the fault it is 3 percent.

A few plates of columbite occur in the zoned pegmatite. The largest specimen seen on the dump was 3 inches long, 1 inch wide, and one-half inch thick.

PEGMATITE 68

Pegmatite 63, 31/2 feet thick, is exposed for 8 feet along its strike of N. $45^{\circ} \mathrm{E}$. It dips $80^{\circ} \mathrm{SE}$. and is nearly concordant. It is quartz-perthite-plagioclase $\left(\mathrm{An}_{6}\right)$-muscovite pegmatite with accessory garnet.

\section{PEgMaTITE 64}

Pegmatite 64, a discordant body, is at least 500 feet long and 10 to 50 feet thick; it strikes N. $45^{\circ}$ W., and dips $70^{\circ} \mathrm{SW}$. Zoning consists of a 6 -inch wall zone of fine-grained quartz-muscovite-plagioclase pegmatite and a fine- to medium-grained core of quartz, plagioclase (locally $A n_{1}$ ), and perthite. White beryl is a minor accessory mineral in both units; in the wall zone it contains 13.1 percent $\mathrm{BeO}$, in the core 12.8 to 13.0 percent $\mathrm{BeO}$. The beryl content of the entire pegmatite is 0.003 percent. Possible products are millinggrade feldspar and scrap mica.

\section{PEgmatite 65, MILIS PROSPECT}

Pegmatite 65 is at least 250 feet long and as much as 60 feet thick. It is discordant, strikes N. $45^{\circ} \mathrm{W}$., and probably dips $75^{\circ} \mathrm{NE}$. Three small prospect pits have been opened for feldspar. The body consists of a wall zone of fine- to medium-grained quartz-perthiteplagioclase $\left(\mathrm{An}_{4-6}\right)$-muscovite pegmatite, a core-margin zone of medium- to coarse-grained perthite-quartz pegmatite, and segments of a discontinuous core of quartz. Beryl (12.9 to 13.0 percent $\mathrm{BeO}$ ) is a minor accessory mineral in the wall zone and in the core. The beryl content of the wall zone is 0.04 percent. Possible products are hand-cobbed perthite and milling-grade feldspar, scrap mica, and beryl.

\section{PEgMatite 66}

Pegmatite 66 is intermittently exposed for 200 feet along its strike of $\mathrm{N} .65^{\circ} \mathrm{E}$., and it dips $65^{\circ} \mathrm{NW}$. It is 15 to 20 feet thick and concordant. The poor exposures show a border zone of fine-grained quartz-muscovite-plagioclase pegmatite less than 1 inch thick, a wall zone of fine- to medium-grained quartz-plagioclase-perthite pegmatite, and segments of a discontinuous quartz-pegmatite core. Muscovite is an accessory mineral in the wall zone and in the core. Possible products are milling-grade feldspar and scrap mica.

\section{PEGMATITE 67}

Pegmatite 67, a discordant, irregular pegmatite, is about 3 feet thick and is exposed for 20 feet downdip. It probably strikes N. $20^{\circ} \mathrm{W}$. and dips $20^{\circ} \mathrm{E}$. It is unzoned, and consists of fine- to medium-grained quartz-plagioclase $\left(\mathrm{An}_{21}\right)$ pegmatite with accessory perthite, muscovite, and biotite.

\section{PEGMATITE 68}

Pegmatite 68 is at a locality that contains two small irregular pegmatites that are discordant to the folia- 
tion of the wallrock. The larger is exposed for about 10 feet on the face of a cliff, where it strikes N. $40^{\circ}$ W. and dips $80^{\circ} \mathrm{NE}$. The smaller body strikes N. $10^{\circ}$ E. and dips $65^{\circ}$ E. Both are unzoned, and consist of plagioclase-quartz pegmatite with accessory muscovite and biotite.

\section{PEGMATITES 69 TO 73}

Pegmatites 69 to 73 are 3.6 miles S. $43^{\circ}$ W. of Raymond village, and have not been prospected. Plate 13 shows the very irregular shape of the pegmatites, and the characteristically poor bedrock exposures in this area.

Pegmatite 69, the largest, probably is 850 feet long and as much as 250 feet wide. It is thickest near the southwest end, and four narrow fingerlike bodies extend northeastward from it. The average strike is N. $65^{\circ} \mathrm{E}$. parallel to the foliation of the gneissic granite wallrock. The average dip is $50^{\circ} \mathrm{NW}$, at a lower angle than the dip of foliation, which averages $70^{\circ} \mathrm{NW}$. The direction or angle of plunge could not be determined, but the shape of the pegmatite and its relation to topography suggest a westward plunge. Under this interpretation, the fingers are roots extending downward from the bulbous part of the body, and the small patch of wallrock near the southwest end is a remnant of the cap over the top of the body.

The largest pegmatite (No. 69) consists of perthite, plagioclase, and quartz with accessory muscovite, biotite, garnet, beryl, and columbite. The pegmatite is poorly zoned, and the exposures are so scattered and small that no attempt was made to map the units. At least two zones are present, a wall zone of fine- to medium-grained plagioclase-quartz-perthite pegmatite, and a medium- to coarse-grained core of perthitequartz-plagioclase pegmatite. The average composition of the wall zone is 50 percent plagioclase, 35 percent quartz, 10 percent perthite, and 5 percent accessory minerals such as muscovite, biotite, garnet, and beryl. The average composition of the core is 45 percent perthite, 30 percent quartz, 20 percent plagioclase, and 5 percent accessory minerals such as muscovite, garnet, and some beryl. The wall zone may be 10 to 20 feet thick; it is the only unit present in some of the fingers that extend northeastward. The core is exposed in the thicker parts of the pegmatite; podlike masses of coarse-grained quartz, perthite, and muscovite are in the perthite-rich core.

A few thin, fracture-controlled units cut the wall zone along the hanging-wall side of the pegmatite, and one extends into wallrock. These are commonly from 5 to 10 feet long, as much as 3 feet thick, and are about normal to the contact. Most of these units consist of quartz pegmatite, and have sharply defined contacts.
Two of them, however, are of medium-grained quartzperthite pegmatite with accessory muscovite and beryl, and have gradational contacts with the earlier formed pegmatite.

Pegmatites 70, 71, and 72 are smaller lenticular or tabular bodies exposed near pegmatite 69. Pegmatite 73 , a tabular body at least 200 feet long and 15 feet thick, strikes N. $70^{\circ}$ E. and dips $40^{\circ} \mathrm{NW}$. A small outcrop of pegmatite in the hanging-wall granite about 25 feet north of the most northeastern pegmatite exposure of pegmatite 73 may be a fracture-controlled extension of this pegmatite that strikes $\mathrm{N} .55^{\circ} \mathrm{W}$., but its junction with the main pegmatite is not exposed.

Pegmatites 70, 71, and 72 consist of plagioclasequartz-perthite pegmatite with accessory muscovite and garnet. The rock is mostly fine grained. Pegmatite 73 has a similar composition but contains very fine grained beryl as a minor accessory mineral. Mineral measurements in one outcrop indicated that 155 beryl crystals had a total exposed area of 7.4 square inches; of this total, 2.4 square inches were in one crystal and most of the others were 0.1 by 0.1 inch. Beryl may be more abundant than the 0.0085 percent indicated by the mineral measurements, because the crystals are so extremely small that they could be seen only in fresh exposures, and there may be other crystals that were not observed.

Products of possible economic value from pegmatites 69 and 73 are milling-grade feldspar, scrap mica, and beryl. Although perthite crystals as much as 1 foot in diameter occur most are less than 4 inches across, and are so surrounded by finer grained quartz, plagioclase, and muscovite that they would be very difficult to recover by hand-cobbing. Muscovite commonly occurs in books or flakes less than 1 inch in diameter. The beryl content of pegmatite 69 , except for the two central fingers that contain no distinguishable beryl, is about 0.03 percent. The crystals are small, the average area exposed is 0.8 square inch, and they could be recovered only by milling. The beryl content of pegmatite 73 is 0.0085 percent, and the crystals are extremely fine grained.

\section{PEGMATITE 74}

Exposures of pegmatite 74 extent intermittently for at least 360 feet $\mathrm{N} .65^{\circ} \mathrm{E}$. The average exposure width is about 25 feet. The dip at the southwest end is $60^{\circ}$ NW., and the body is concordant. The pegmatite contains 4 fracture-filled units, 3 of which extend into wallrock; the first strikes N. $15^{\circ} \mathrm{W}$., is 15 feet long, and 3 feet thick; the second strikes N. $35^{\circ} \mathrm{W}$., is 50 feet long, and 12 feet thick; the third strikes north, is 35 feet long, and 11 feet thick; and the fourth is wholly in pegmatite, strikes N. $45^{\circ}$ W., is 5 feet long, and 1 
foot thick. All dip vertically. Junctions of the first three with the main pegmatite are not exposed. The main pegmatite is chiefly unzoned, containing fine- to medium-grained perthite, quartz, and plagioclase $\left(A n_{5}\right)$, and muscovite and beryl (12.8 to 12.9 percent $\mathrm{BeO}$ ) as minor accessory minerals. The beryl content of the entire pegmatite, including the fracture-controlled bodies, is 0.0125 percent. The fracture-controlled bodies are zoned, especially the one to the southwest, where a wall zone of fine-grained plagioclase-perthite-quartz pegmatite contains minor accessory beryl ( 13.0 percent $\mathrm{BeO})$, and the core consists of fine- to medium-grained quartz-perthite pegmatite. Possible products of this pegmatite are milling-grade feldspar, scrap mica, and beryl.

\section{PEGMATITE 75}

Pegmatite 75 is unzoned, discordant, and 3 feet thick, and exposed for 10 feet along its strike of N. $10^{\circ} \mathrm{W}$.; it dips $80^{\circ} \mathrm{W}$. It consists of fine- to medium-grained quartz-plagioclase $\left(\mathrm{An}_{5}\right)$-perthite pegmatite with muscovite and beryl (13.0 percent $\mathrm{BeO}$ ) as minor accessory minerals.

\section{PEgMATITE 76}

Pegmatite 76 is at a locality that contains a group of concordant pegmatite lenses and tabular bodies exposed near the contact of foliated granite with micaquartz schist. Many quartz bodies are associated with the pegmatitic material; some of them plunge $20^{\circ} \mathrm{N}$. $55^{\circ} \mathrm{E}$. The largest pegmatite is an unzoned body 50 feet long and 3 feet thick; it is perthite-plagioclasequartz pegmatite with minor accessory beryl (13.1 percent $\mathrm{BeO}$ ) and muscovite.

\section{PEGMATITE 77}

Pegmatite 77 is concordant, and is at least 170 feet long and from 3 to 15 feet thick. It strikes N. $60^{\circ}$ E. and dips $50^{\circ} \mathrm{NW}$. It is an unzoned fine- to mediumgrained perthite-plagioclase-quartz pegmatite with minor accessory muscovite and beryl (12.9 percent $\mathrm{BeO}$ ). The beryl content of the entire pegmatite is 0.019 percent. Possible products are milling-grade feldspar and scrap mica.

\section{PEGMATITE 78}

Pegmatite 78 is exposed intermittently for 105 feet along its strike of $\mathrm{N} .65^{\circ} \mathrm{E}$. The average exposed thickness is 4 feet, and the dip is unknown. It probably is concordant. Although poorly zoned, it has a finegrained wall zone of quartz-muscovite-plagioclase pegmatite and a core of fine- to medium-grained perthiteplagioclase-quartz pegmatite containing accessory muscovite and minor accessory beryl (13.0 percent $\mathrm{BeO})$.
The beryl content of the entire pegmatite is 0.015 percent.

\section{PEGMATITE 79}

Pegmatite 79 is 10 inches thick and is exposed for only $2 \frac{1}{2}$ feet along its strike of N. $55^{\circ}$ E.; it dips $80^{\circ}$ $\mathrm{NW}$., concordant with the schist. It is fine-grained quartz-muscovite-plagioclase $\left(\mathrm{An}_{14}\right)$ pegmatite.

\section{PEGMATITE 80}

Pegmatite 80 is 1 foot thick and is exposed intermittently for 20 feet along its strike of N. $60^{\circ}$ E.; it dips $85^{\circ} \mathrm{NW}$. It is concordant, unzoned, and consists of fine-grained quartz-plagioclase $\left(\mathrm{An}_{3-4}\right)$ pegmatite with accessory muscovite.

\section{PEgMATITE 81}

Pegmatite 81 is 1 foot thick, is exposed intermittently for 60 feet along its strike of N. $60^{\circ}$ E., and dips $80^{\circ}$ NW. It is concordant, unzoned, and contains finegrained quartz-plagioclase pegmatite with accessory muscovite.

\section{PEGMATITE 82}

Pegmatite 82, a concordant body at least 280 feet long and from 10 to 15 feet thick, strikes N. $65^{\circ}$ E. and dips $65^{\circ} \mathrm{NW}$. It contains a wall zone of fine- to medium-grained plagioclase-quartz-perthite pegmatite and segments of a discontinuous core of mediumgrained quartz-plagioclase-perthite pegmatite. Plagioclase in the wall zone ranges in composition from $\mathrm{An}_{1}$, where associated with quartz near the core, through $\mathrm{An}_{3-4}$, also near the core, to $\mathrm{An}_{6-7}$ near the hanging wall, and to $\mathrm{An}_{12}$ where associated with minor accessory columbite near the hanging wall. Beryl is a minor accessory mineral of both the core and the wall zone, and ranges in composition from 12.7 to 12.9 percent $\mathrm{BeO}$ in the core, to 12.9 to 13.1 percent $\mathrm{BeO}$ in the wall zone. The beryl content of the entire pegmatite is 0.127 percent. Muscovite is an accessory mineral of both units. Possible products are milling-grade feldspar, scrap mica, and beryl.

\section{PEGMATITE 83, GILIINGHAM PROSPECT}

The Gillingham prospect is an unzoned pegmatite opened for feldspar by the Whitehall Co., Inc. The pegmatite is 15 feet thick and at least 60 feet long. It strikes eastward, dips $75^{\circ} \mathrm{S}$., and the east end terminates in a blunt nose. It is medium- to coarsegrained perthite-quartz-plagioclase-muscovite pegmatite. Black tourmaline and apatite are accessory minerals, and beryl (13.0 to 13.1 percent $\mathrm{BeO}$ ) is a minor accessory mineral. Plagioclase $\left(\mathrm{An}_{1-3}\right)$ veinlets from the finer grained matrix cut perthite. The beryl content of the entire pegmatite is 0.088 percent. Pos- 
sible products are hand-cobbed perthite and feldspar, and scrap mica of milling grade.

\section{PEGMATITES 84 TO 86, HURLET PROSPECT}

The three pegmatites at the Hurley prospect are 4.2 miles S. $52^{\circ}$ W. of Raymond village. In 1947 the overburden was removed from most of the central and western pegmatites and two small cuts were opened by the Whitehall Co., Inc.

The easternmost pegmatite, No. 84 (pl. 14), is at least 120 feet long and as much as 45 feet thick. It strikes about N. $40^{\circ} \mathrm{W}$. and dips $80^{\circ} \mathrm{NE}$. The central pegmatite, No. 85 , is also at least 120 feet long and as much as 45 feet thick; it strikes about N. $35^{\circ} \mathrm{W}$. and probably dips steeply northeastward. A roll on the footwall contact plunges $60^{\circ} \mathrm{S} .55^{\circ} \mathrm{E}$. The westernmost and largest pegmatite, No. 86 , strikes about $\mathrm{N}$. $60^{\circ} \mathrm{W}$., and where the contact is exposed, dips $65^{\circ} \mathrm{NE}$.

Pegmatites 84 and 85 are separated by a northwestward-trending band of schist probably ranging from 8 to 10 feet in thickness; the schist separating pegmatites 85 and 86 is 2 to 18 feet thick. Schist is exposed in the southeast corner of the main opencut, and its probable relation to pegmatite 86 is shown in plate 14, section $A-A^{\prime}$. The attitude of bedding in the narrow schist bands between the pegmatite bodies is similar to that in schist some distance from the contact. The outcrop pattern indicates that the pegmatite exposures may be parts of a single body, only partly exposed by erosion, which strikes about N. $80^{\circ} \mathrm{W}$. and dips northward. The diagonal bands of wallrock are most likely uneroded remnants of the original cap of this body. Furthermore, the three pegmatites are similar in composition.

The border zone consists of very fine grained quartzmuscovite pegmatite that is not everywhere exposed along the contact. It is rarely more than one-half inch thick.

The wall zone is medium-grained plagioclase-quartzperthite pegmatite with accessory muscovite, biotite, black tourmaline, garnet, and sulfides. The average composition is about 45 percent plagioclase, 25 percent quartz, 25 percent perthite, and 5 percent accessory minerals. Locally, the perthite content may increase to 50 percent, and some is in graphic intergrowth with quartz. Plagioclase near the inner edge of the unit is partly cleavelandite. Much of the feldspar is stained by iron oxides along cleavages and fractures. The wall zone is the largest unit exposed, and is the only unit exposed in the easternmost pegmatite.

The intermediate zone contains the same minerals as the wall zone plus strips of intergrown biotite and muscovite. The average composition is $\mathbf{4 5}$ percent plagioclase, 30 percent quartz, 10 percent perthite, 10 percent intergrown biotite and muscovite, and 5 percent accessory minerals. The biotite is partly chloritized. The biotite-muscovite intergrowths occur as strips as much as 11/2 feet long, 3 inches wide, and onehalf inch thick. Cleavelandite is more abundant in pegmatite of this zone than in the wall zone, and comprises about 25 percent of the plagioclase. The intermediate zone completely encloses 1 of the 3 exposures of the core, partly surrounds the second, but is not exposed in the vicinity of the third.

The core is coarse-grained perthite-quartz pegmatite. Some of the exposures of this unit shown on the map (pl. 14) are very quartz rich, and others are perthite rich, but all are probably parts of a single central unit of the pegmatite. Accessory minerals are plagioclase (commonly cleavelandite), muscovite, minor biotite, black tourmaline, beryl, columbite, and löllingite. The composition ranges from about 85 percent perthite and 15 percent quartz on the east wall of the larger opencut to 65 percent quartz, 20 percent perthite, 10 percent plagioclase, and 5 percent accessory minerals in the exposure east of the north end of the larger opencut. At the exposure south of the larger cut, the composition is 75 percent quartz and 25 percent perthite with minor amounts of accessory minerals. In the perthiterich areas, the feldspar is slightly stained by iron $o x-$ ides. In the quartz-rich areas, perthite occurs as large euhedral crystals in the quartz. The quartz of the unit ranges from gray to pink to white, and there are small areas of clear, highly fractured, colorless quartz.

Resources of potassic feldspar recoverable by handcobbing occur only in the core. Present exposures of this unit are small, but if the three pegmatites are connected at depth, the size of the core would be increased with a proportional increase in resources of hand-cobbable perthite.

Sodic feldspar is too fine grained to be recovered by hand-cobbing. The use of the entire pegmatite for millfeed would permit the recovery of much of the plagioclase as well as much of the perthite. The presence of biotite, garnet, and black tourmaline in the different units would require additional equipment for removing iron-bearing minerals.

Some small sheets of hard flat clear ruby mica as much as 2 by 2 inches in diameter could be obtained from muscovite-biotite intergrowths of the intermediate zone, but economically important quantities of sheet mica could not be produced. Scrap mica could be recovered by milling methods because muscovite is a constituent of each unit of the pegmatite, although the size of most of the books is too small for hand-cobbing. Biotite is a contaminant that might have to be removed. 


\section{PEGMATITE 8\%}

Pegmatite 87 is a poorly exposed unzoned body that extends for 40 feet $\mathrm{N}$. $50^{\circ} \mathrm{W}$. Its maximum thickness probably is less than 20 feet. It is perthite-plagioclasequartz pegmatite with minor accessory muscovite. Possible products are milling-grade feldspar and scrap mica.

\section{MINOR DISTRICTS}

Although many pegmatites occur in scattered areas remote from the well-known pegmatite mining districts of Grafton and Keene, few of economic interest have not been studied. Of the two pegmatites selected for careful study, one was developed after World War II, and the other has been prospected since last described in 1943.

\section{MILLARD CHANDLER MINE}

The Millard Chandler (North Star) feldspar mine is in the town of Chatham, Carroll County, and is 1.15 miles N. $7^{\circ} \mathrm{E}$. of the village of North Chatham. It is on a steep hillside about one-quarter mile west of the Evans Notch Road at a point about one-half mile west of the New Hampshire-Maine boundary. The mine was worked for feldspar before World War II by the Whitehall Co., Inc. An opencut 70 feet long, 50 feet wide, and as much as 45 feet deep has been driven westward into the pegmatite (pl.15).

The pegmatite is exposed for 360 feet along its strike. Near the opencut it is about 60 feet thick, but it thins southward and thickens northward. It strikes about north and dips from $10^{\circ}$ to $35^{\circ} \mathrm{W}$. The steeper dips are on the footwall contact, but these may represent only a local steepening of a generally low dip to the west. The pegmatite is slightly discordant to the structure of the wallrock, which strikes from N. $5^{\circ}$ to $40^{\circ} \mathrm{E}$., averaging $\mathrm{N} .20^{\circ} \mathrm{E}$., and dips from $10^{\circ}$ to $35^{\circ} \mathrm{W}$., averaging about $15^{\circ} \mathrm{W}$. The wallrock is a mediumgrained granite gneiss formed by the introduction of granitic, and locally pegmatitic, material into biotite schist. Four mafic dikes, ranging from 6 inches to 2 feet in thickness, cut pegmatite and wallrock in and north of the opencut. Most of these strike N. $30^{\circ} \mathrm{E}$. and $\operatorname{dip} 70^{\circ}$ to $75^{\circ} \mathrm{SE}$. Two additional mafic dikes south of the opencut are from 4 to 6 feet thick, strike more eastward than the others, and dip from $65^{\circ}$ to $75^{\circ} \mathrm{S}$. These dikes have sharp but irregular contacts with pegmatite and wallrock, and in detail are seen to have many small apophyses extending into the surrounding rock. Five units have been distinguished at the mine. Contacts between the units are gradational and very irregular, and the contacts shown on plate 15 are generalized.

The narrow border zone is fine-grained quartz, plagioclase $\left(A n_{10}\right)$, perthite, and muscovite with acces- sory biotite and garnet. It is similar to the gneissic bands of the granitic and pegmatitic material in the wallrock, and for this reason the actual contact of the pegmatite is difficult to distinguish. The accessory biotite and garnet may contain material derived from the wallrock.

The wall zone is fine- to medium-grained plagioclasequartz pegmatite. About 50 percent of the unit is plagioclase $\left(\mathrm{An}_{6}\right), 30$ to 45 percent is quartz, and 5 to 15 percent is perthite. Muscovite is commonly present, and biotite, garnet, and apatite are minor accessory minerals. The wall zone is thickest on the footwall side of the pegmatite.

The core-margin or intermediate zone is the most irregular. The average composition is 40 percent perthite and graphic granite, 35 percent plagiocase, and 25 percent quartz. The coarse-grained perthite and graphic-granite masses are surrounded by fine- to medium-grained plagioclase-quartz pegmatite of a composition similar to the wall zone and to small areas surrounding perthite in the core. Perthite occurs mostly as graphic granite in which the quartz intergrowths are less angular and less regular in spacing than in typical graphic granite. Potassic feldspar increases in abundance toward the core. Beryl and scrap muscovite are present adjacent to the core, particularly in areas of plagioclase and quartz between the graphic granite masses. Locally, there are many small vugs in the plagioclase $\left(A n_{6}\right)$. Some beryl crystals are rimmed and cut by veinlets of cleavelandite; one of these veinlets contains plagioclase of higher sodic content $\left(\mathrm{An}_{3}\right)$ than the normal type in the zone. A few books of scrap muscovite as large as 4 by 3 by 1 inches occur adjacent to the core.

The core consists of coarse-grained quartz and perthite with small areas of medium-grained plagioclasequartz-muscovite pegmatite. Perthite crystals are as large as $31 / 2$ by 6 by 2 feet, and aggregates of crystals are even larger. Locally, the unit may consist entirely of either quartz or perthite, but the average content ranges from 55 to 60 percent quartz, and 40 to 45 percent perthite. The core is discontinuous in surface exposures, but appears to thin southward and thicken northward, as does the pegmatite. Lollingite and sulfides are minor accessory minerals in this unit.

A very fine grained sugary-textured plagioclase-rich unit is south of the opencut. It is exposed for a length of 35 feet and a width of 5 feet, and its location in the sequence of pegmatite units suggests that a section of the core of the body has been replaced by plagioclaserich material. This unit consists of 80 to 90 percent plagioclase $\left(\mathrm{An}_{6}\right)$ with minor quartz and greenish muscovite. Garnet is a rare accessory mineral. 
Beryl occurs in the intermediate zone adjacent to the core. It is in blue-green to light-green crystals as large as 6 by 15 inches. Some crystals contain veinlets of, and are rimmed with, cleavelandite. Mineral measurements indicate a beryl content of about 0.10 percent, of which 80 percent could be recovered by hand-cobbing. The beryl contains from 13.5 to 13.7 percent $\mathrm{BeO}$.

Potassic feldspar is economically the most important mineral in the pegmatite. The largest reserves are in the core and intermediate zone. Most of the perthite in the core and perhaps one-half of it in the intermediate zone could be recovered by hand-cobbing. In the intermediate zone, however, the product would be quartz rich because of the high proportion of graphic granite. There are no iron-bearing minerals in the pegmatite to contaminate a mill product, but the mafic dikes would cause contamination in any large-scale operation.

No sheet mica was seen at the mine. Scrap mica could be recovered from all units by milling, but the mica content of this pegmatite is small. Some books of scrap mica in the intermediate zone adjacent to the core could be recovered by hand-cobbing.

\section{PaRker Mountain Mine}

The Parker Mountain (Foss, Foss Ledge) mine is in the town of Strafford, 2.4 miles N. $46^{\circ} \mathrm{W}$. of Center Strafford village, Strafford County. The pegmatite has been described by Sterrett (1923, p. 156-158), Switzer (1938), and most recently by Stewart (in Cameron and others, 1954, p. 270-271). In 1947, the Whitehall Co., Inc., removed the overburden from pegmatite at the southeast end of the opencut while prospecting for feldspar. This permitted a more extensive study of the internal structure of the pegmatite than was possible in 1943 when Stewart did his work. Although his map is used as a base for plate 16, minor changes were necessary to bring it up to date and to show the slightly different interpretation of the internal structure.

The old working at the Parker Mountain mine is an opencut 100 feet long, from 10 to 75 feet wide, and as much as 40 wide deep. Narrow inclined stopes extend for an undetermined distance below the present floor of the cut along the hanging wall of the pegmatite. These stopes are now filled with waste rock and water. The mine was last operated in 1936-38 by A. E. Buzzo of Center Strafford, who worked it for feldspar (Cameron and others, 1954, p. 270-271). Although the mine was prospected by the Whitehall Co., Inc., in 1947 , no production was reported.
The wallrock of the pegmatite is fine-grained massive aplite consisting of quartz, microcline, albite $\left(\mathrm{An}_{6}\right)$, muscovite, and minor amounts of tourmaline, biotite, and apatite (Cameron and others, 1954, p. 270271). The aplite body trends N. $25^{\circ} \mathrm{E}$., is at least 130 feet wide, and is in quartz-mica schist that strikes about north and dips $40^{\circ}$ to $60^{\circ} \mathrm{W}$.

The pegmatite apparently was emplaced along a fracture in the massive aplite body. The pegmatite strikes N. $40^{\circ} \mathrm{W}$, dips $70^{\circ}$ to $80^{\circ} \mathrm{NE}$., and extends diagonally across the entire width of the aplite body. It is lenticular and has a miximum thickness of 40 feet.

Four internal structural units have been mapped in the Parker Mountain pegmatite. These are similar to the ones described by Stewart (in Cameron and others, 1954, p. 270-271) but differ slightly because of the relations and compositions shown in new exposures southeast of the opencut.

The border zone consists of fine-grained perthite and quartz in graphic granite. The thickness ranges from 1 inch to 3 feet, and is commonly too thin to show on the map and section. This unit is most prominent along the hanging-wall contact, but is absent in many places elsewhere.

The wall zone is medium-grained perthite-cleavelandite-quartz-muscovite pegmatite with minor accessory beryl, black tourmaline, and apatite. It is a discontinuous unit as much as 5 feet thick on the hanging-wall side; most exposures are remnants left on the hanging-wall and footwall sides of the opencut.

The first intermediate zone is medium-grained perthite-cleavelandite-quartz pegmatite of a texture and composition similar to the wall zone except that muscovite is only an accessory mineral. The unit is discontinuous; it is most conspicuous on the footwall side of the pegmatite, and extends entirely across the pegmatite southeast of the opencut where it seems to form a cap over the core.

The core consists of coarse-grained quartz-perthite pegmatite with accessory cleavelandite and muscovite and minor quantities of accessory beryl, garnet, apatite, triphylite, spodumene, and other minerals. The average composition is 50 percent quartz, 40 percent perthite, and 10 percent accessory minerals. Quartz is intergrown with perthite and also occurs as individual bodies as much as 5 feet wide and 25 feet long. Most of the quartz is gray, but colorless and dark smoky quartz also are present. The core is as much as 20 feet thick.

A pipelike body of medium-grained muscovite-perthite-quartz-cleavelandite pegmatite is centrally located in the core near the northwest end of the opencut. It is as much as 6 feet across but its length is unknown. 
Beryl occurs in the wall and first intermediate zones and in the core. The beryl content of the core in the outcrop southeast of the opencut is 0.22 percent. The average crystal has an exposed area of 7 square inches, and most of the beryl could be recovered by hand-cobbing. The wall zone on the southwest side of the opencut contains 0.89 percent beryl; the average crystal has an area of 5 square inches, and much of this beryl also could be recovered by hand-cobbing. No beryl was seen in the hanging-wall part of the wall zone. The beryl of the core is blue green and is associated chiefly with the larger quartz bodies. Beryl from the wall zone is light green and is associated with muscovite.

Most of the resources of potassic feldspar are in the core below the level of present exposures and below the waste rock in the floor of the opencut. Most perthite in the core could be recovered by hand-cobbing. Perthite also is in the other units of the pegmatite but could be recovered from them only by milling.

Sodic feldspar, mostly cleavelandite, is in every unit, but the grains are too small to permit economic recovery by hand-cobbing. The use of the entire pegmatite for millfeed would result in the recovery of the plagioclase in addition to the potassic feldspar.

Sheet mica has been recovered from the wall zone of the pegmatite, particularly on the hanging-wall side, and reserves of sheet mica probably are in this unit below the old workings. Scrap-mica reserves are most abundant in the pipelike unit of muscovite-rich pegmatite. About 80 percent of the unit is muscovite, most of which is recoverable by hand cobbing. Muscovite is also in the other units but except in the sheet-micabearing wall zone, would be recoverable only by milling.

The pegmatite also contains columbite, spodumene, and triphylite, and according to Switzer (1938, p. 811820 ), it contains amblygonite, cassiterite, and autunite. The quantities of these minerals available at the Parker Mountain mine are too small to be of value under present economic conditions (1957).

\section{RECONNAISSANCE OF OTHER AREAS}

\section{ALTON QUADRANGLE}

Three pegmatites have been worked or prospected in the Alton quadrangle, all of them in the town of Strafford. The largest working is at the Parker Mountain (Foss, Foss Ledge) mine previously described. The John Felker mica prospect, the Ashton Rollins prospect, and from 20 to 25 other pegmatites on the Rollins property also have been described by Stewart (in Cameron and others, 1954 , p. 270-274). With the exception of the Parker Mountain pegmatite, none of these seems to offer economic possibilities for future production of sheet or scrap mica, feldspar, or beryl.

Five other small pegmatites, also in Strafford, were studied in 1949 during the short time spent on reconnaissance in this quadrangle. The largest one is about one-fourth of a mile north of the road intersection east of the Blue Hills School. This pegmatite is exposed for nearly 100 feet in the bed of a stream, strikes $\mathrm{N}$. $45^{\circ}$ E., dips $60^{\circ}$ SE., and is 20 feet thick. An 8-inch border zone of fine-grained, quartz-muscovite pegmatite and a core of perthite-quartz pegmatite are the only internal units exposed. Lath-shaped perthite crystals in quartz of the core commonly have their long axes oriented normal to the contact. Accessory black tourmaline crystals have a similar orientation. The other pegmatites visited are very small and are unzoned.

\section{GORHAM QUADRANGLE}

Two pegmatites have been worked or prospected in the Gorham quadrangle. The Millard Chandler (North Star) mine is in the town of Chatham. It was operated for feldspar by the Whitehall Co., Inc. in 1940. A study of this mine was undertaken in August 1949, and the results are discussed on pages 43-44. The deposit has small reserves of feldspar, scrap mica, and beryl. The Fischer mica prospect is in the town of Shelburne and has been described by Larrabee (in Cameron and others, 1954, p. 139). This property has never been worked and does not seem to offer any possibilities for the production of economic pegmatite minerals.

The results of a brief reconnaissance in 1949 indicate that this quandrangle is unfavorable for the production of pegmatite minerals. Large parts of the quadrangle are comparatively inaccessible, and the transportation difficulties in these areas would be great. For this reason, the reconnaissance was confined to a few of the more accessible areas adjacent to the Wild River in Beans Purchase, the Androscoggin River in Shelburne, and the Peabody River in Pinkham Notch. The pegmatites examined represent only a very small fraction of the actual number in the area. The pegmatites are small, rarely more than 5 feet thick or 50 feet long, and most are tabular or lenticular. They are commonly concordant to the foliation of the enclosing quartzmica schist and gneiss. Locally, the pegmatites seem to have filled openings between blocks of a coarse breccia and are very irregular and variable in size. They are principally unzoned bodies of fine- to medium-grained perthite-plagioclase-quartz pegmatite. Accessory minerals are muscovite, biotite, black tourmaline, and garnet. No beryl was seen. Commercial quantities of feldspar are lacking, and only a few small books of sheet mica were seen. 


\section{MOUNT PAWTUCKAWAT QUADRANGLE}

Reconnaissance in the Mount Pawtuckaway quadrangle was a logical outgrowth of detailed mapping in the Raymond pegmatite district. The results of the Raymond district study were sufficiently favorable to warrant an investigation of adjoining areas in search of pegmatites of possible economic interest. A reconnaissance was made in the Mount Pawtuckaway quadrangle northeastward from the Raymond pegmatite district to near the village of Nottingham Square. A smaller pegmatite district was studied in the towns of Deerfield and Northwood, mainly between Deerfield Center and Coffeetown School, and scattered pegmatite outcrops were seen elsewhere in the quadrangle. In addition, areas were examined south, southwest, and west of the Mount Pawtuckaway quadrangle in the Hampstead, Manchester, and Suncook quadrangles, respectively, but only a fow pegmatites were seen.

Bedrock exposures are sparse in large parts of the Mount Pawtuckaway quadrangle, and pegmatites occur in only a few of these exposures. Except in the Raymond district, where nearly every pegmatite outcrop was examined, the reconnaissance nature of the work resulted in the study of only those pegmatites that were seen along traverse lines and in road cuts.

The geology of the Mount Pawtuckaway quadrangle has been mapped and described by Freedman (1950, p. 449-491). The petrology of the igneous complex in the Pawtuckaway Mountains has been described by Roy and Freedman (1944, p. 905-919).

Freedman (1950, p. 449-491) shows that metamorphosed sedimentary rocks trend northeastward across the southeast half of the quadrangle. They form the steeply dipping southeast limb of a syncline that probably plunges northeastward and includes the Eliot formation (probably Ordovician and Silurian) consisting of phyllite, quartz-mica schist, quartzite, and lime-silicate rock; the Berwick formation (probably Ordovician and Silurian) also consisting of phyllite, quartzite, quartz-mica schist, and lime-silicate rock; and the Littleton formation (Lower Devonian) consisting of quartzite, mica-schist, mica-garnet schist, mica-staurolite schist, and mica-sillimanite schist. Rocks of the New Hampshire plutonic series (Upper Devonian?) are widespread in the northwest half of the quadrangle, where they consist of quartz diorite, quartz monzonite, binary granite, and microcline granite. Quartz monzonite is the most abundant rock unit of the series and is discordant to the Littleton formation that adjoins it on the southeast; offshoots of the quartz monzonite locally extend across the Littleton into the Berwick formation. Rocks of the White Mountain plutonic-volcanic series (Mississippian?), ranging in composition from monzonite to gabbro, are best exposed in the Pawtuckaway Mountains, where they were emplaced in quartz monzonite of the New Hampshire plutonic series by forceful injection and cauldron subsidence. Metamorphism decreases southeastward and northwestward from the granitic rocks of the New Hampshire plutonic series. The pegmatites of the quadrangle are associated with rocks of the New Hampshire plutonic series and are not found with younger rocks.

In addition to the 87 pegmatites of the Raymond district described elsewhere in this report, 4, the Corson, McMullen, McGall, and Vatcher pegmatites are described in the section on detailed studies of individual mines in the Raymond region. In the Mount Pawtuckaway quadrangle 85 other pegmatites or groups of pegmatites were investigated. Of these, 61 are in the metamorphic rocks and in small associated bodies of igneous rocks between the Raymond district and the village of Nottingham Square. In the towns of Deerfield and Northwood 24 were visited; most of these are between the village of Deerfield Center and the Coffeetown School.

Mica schist is the wallrock of most of the pegmatites in the towns of Raymond, Nottingham, and Epping. A few pegmatites are in small bodies of schist surrounded by granitic rocks; others are in small granite bodies in metamorphic rocks. In the Raymond district, the pegmatites are in the Littleton formation, $11 / 2$ to 2 miles southeast of its contact with granitic rocks. The McGall, Vatcher, and Corson pegmatites and the pegmatite area near Nottingham Square are at or near the contact of the Littleton and Berwick formations. With the exception of the McGall pegmatite, these are about 11/2 miles from the main granitic rocks. The pegmatites in the towns of Deerfield and Northwood are in igneous rocks or in metamorphic rocks included in, or adjacent to, the igneous rocks.

Most of the pegmatites are thin tabular or lenticular bodies that range from 5 to 1,000 feet in length and from a few inches to 300 feet in thickness; the average body is exposed for about 50 feet along its strike and is about 10 feet thick. The attitudes of many pegmatites are difficult or impossible to determine because of the absence of exposures showing contacts with wallrock. Nearly half of those in the Raymond district are concordant to the bedding of the enclosing wallrock, as are about two-thirds of those between the Raymond district and Nottingham Square. In the Deerfield area, more than half are concordant.

Internal structural units were not distinguishable in many pegmatites because of the poor exposures. The best examples of zoning are at mines or prospects where 
small opencuts have been developed or where the overburden has been removed. Many other pegmatites would show internal structural units if better exposures were available.

The upper surfaces of many of the pegmatites seem to have been uncovered by erosion recently during the geologic history of the district. Small patches of schist and border-zone material occur on the upper surfaces of several outcrops. The dips of contacts indicate that some pegmatites thicken at depth, suggesting that only their tops have been uncovered. At several of the mines and prospects, a greater variety of zones is found in the walls and floors of the opencuts than is exposed at the surface, and wall zones can be seen to form a capping over other zones. Although many of the other pegmatites seem to consist of only two units-a thin border zone and an apparent core that has the composition and texture of typical wall zones-if erosion had extended to slightly greater depths additional zones might have been exposed. When further prospecting is done in the district, it should be confined to the thicker bulbous parts of the pegmatites in which unexposed inner zones are most likely to be found.

No zoned pegmatites were seen in the Deerfield area, but elsewhere 2 to 5 zones were recognized in pegmatites observed during the reconnaissance study. A border zone is commonly adjacent to the wallrock, and consists of very fine grained quartz-muscovite pegmatite with or without plagioclase; it is rarely more than 1 inch thick, and in many places less than one-quarter inch thick. The wall zone, the unit next inside the border zone, may be the only other unit exposed, and thus is an apparent core. It normally has a fine- to mediumgrained texture and consists of plagioclase, quartz, and perthite with accessory muscovite. The first intermediate zone, where present, consists of perthite, quartz, and plagioclase. It is coarser grained and contains more perthite and less plagioclase than the wall zone. The second intermediate zone, or core-margin zone, is 1 to 2 feet thick and consists of perthite, quartz, and muscovite. This zone surrounds a quartz core or small quartz bodies that are segments of a discontinuous core. These quartz bodies, however, should not be confused with quartz pods that are randomly distributed throughout many unzoned pegmatites.

The only other internal structural units are fracturecontrolled bodies that are either crosscutting or parallel with the zones. These commonly are a few inches thick, less than 10 feet long, and consist chiefly of quartz. One pegmatite in the Nottingham Square area contains fracture-controlled bodies ranging from 5 to 10 feet in length and as much as 3 feet in width; these consist of quartz-perthite-muscovite pegmatite with accessory beryl in crystals as large as 3 by 6 inches.

Fifteen pegmatites, excluding those previously described, contain visually distinguishable beryl, but none has a grade or tonnage sufficiently high to warrant commercial operations. The richest pegmatite has a beryl content of 0.124 percent and inferred beryl reserves of about 3 tons. The pegmatite area near Nottingham Square has a higher proportion of beryl-bearing pegmatites than any other area except the Raymond district.

Muscovite is a characteristic mineral of every pegmatite, but it is rarely of sufficient size or quality to be used for sheet mica. Three pegmatites contain minor quantities of sheet mica, and in each the mica is in a different unit. One has sheet mica in a wall zone of cleavelandite-quartz pegmatite, another in a coremargin zone of perthite-quartz pegmatite, and the third in a fracture-controlled unit of quartz-perthitemuscovite pegmatite. Many of the pegmatites contain an estimated 2 to 5 percent muscovite suitable for scrap mica, but the books are so small that milling would be required for economical recovery.

Reserves of potassic feldspar recoverable by handcobbing are small. One characteristic that might favor the use of these pegmatites for milling is the comparative absence of iron-bearing minerals such as biotite, black tourmaline, or garnet.

Production of economically important quantities of pegmatite minerals in the Mount Pawtuckaway quadrangle and adjacent areas will probably be slight; the most favorable deposits are confined almost exclusively to the Raymond district itself. The writers found no new pegmatite deposits of value under present (1957) economic conditions in their reconnaissance of selected pegmatite districts. Further work does not seem to be justified in the Raymond region until other districts in New Hampshire have been more thoroughly examined and their resources have been evaluated. If interest in the pegmatites of this region develops in the future, the most favorable location for further work is between the Raymond district and Nottingham Square.

\section{MOUNT WASHINGTON QUADRANGLE}

In 1949 , a brief reconnaissance was made of the pegmatites on the north flank of Mount Adams, in the town of Randolph, and in Low and Burbanks Grant. The locations of several pegmatites are shown on a geologic map of the quadrangle prepared by M. P. Billings and others (1946).

Three pegmatites in this area were examined, and two others represented only by loose blocks were ob- 
served. The pegmatites are poorly exposed but seem to be discordant bodies of plagioclase, quartz, and perthite in feldspathic quartz-mica gneiss. They are fine- to medium-grained and are chiefly unzoned. The best exposures are of a pegmatite in Spur Brook, Low and Burbanks Grant. The average grain size of this pegmatite is less than 1 inch in greatest dimension but locally perthite crystals are as much as 10 inches long and quartz pods are as much as 4 feet long and 1 foot wide. Small books of greenish muscovite ranging from one-half to 2 inches in diameter are most abundant near the gray quartz pods. None of these pegmatites has reserves of sheet mica or visually distinguishable beryl, and the small resources of millinggrade perthite are not of commercial value.

Pegmatites are present on Mount Washington and Mount Madison, but the comparative inaccessability of all except one located on the Carriage Road on Mount Washington would limit future development to small-scale operations. The pegmatite on the Carriage Road is not suitable for economic development.

\section{PLYMOUTH QUADRANGLE}

The Plymouth quadrangle was selected for reconnaissance in 1949 because of its location east of the northern limit of the productive Grafton district and because of the similarity of rock types. The locations of many of the pegmatites are shown on the geologic map prepared by C. B. Moke (1946). Three mica mines were operated in this quadrangle during 194244: the two Crystal mines in Campton, and the White Mountain Mica Co. (Thornton Hill) mine in Thornton (Cameron and others, 1954, p. 160-162, 259-261). Although the White Mountain Mica Co. mine and one of the pegmatites at the Crystal mines do not contain economically important quantities of sheet mica, the "Upper" Crystal mine has possibilities for future production of this mineral.

During reconnaissance, 30 pegmatites or groups of pegmatites along the valley walls of the Pemigewasset River and its tributaries were examined. Sixteen pegmatites are in quartz-mica schists of the Littleton formation, 13 in Kinsman quartz monzonite, and 1 in Concord granite. The attitude of 28 of the bodies could be determined, and 15 of these are discordant to the structure of the enclosing rock.

Most of the pegmatites are small. Few are exposed for more than 20 feet along their strike, and they range from a few inches to a maximum of 35 feet in thickness, averaging about 5 feet. Eleven pegmatites show a crude zoning; most of them consist of a very thin border zone of quartz-muscovite-plagioclase pegmatite, a wall zone of plagioclase-quartz-perthite pegmatite, and a thin intermediate (core-margin) zone of muscovite pegmatite around small quartz pods that form a discontinuous core. Zoned pegmatites are almost twice as abundant in the quartz-mica schists as in the quartz monzonite. There is no apparent relation between the size of the pegmatite and the presence of zoning.

The pegmatites are fine- to medium-grained, with an average grain diameter of less than 2 inches. Perthite crystals as large as 8 by 12 inches are present in a beryl-bearing pegmatite that crops out in West Branch Brook, on the Campton-Thornton town line. Muscovite books range from one-half to 2 inches in diameter. Strips of intergrown biotite and muscovite as much as 2 by 4 inches and less than one-fourth inch thick were seen in one exposure. Minor accessory garnet, beryl, and black tourmaline occur as small euhedral crystals.

None of the pegmatites seem to contain any mineral or group of minerals in sufficient quantity to warrant their commercial development under present (1957) economic conditions or under those during 1942-45. None is large enough to support the operation of a flotation mill for the recovery of feldspar, and no single area has a reserve tonnage sufficient for such an operation.

The best feldspar and beryl prospect is in West Branch Brook, 3.05 miles N. $39^{\circ} \mathrm{W}$. of West Campton village, on the Campton-Thornton town line. This pegmatite is at least 100 feet long and as much as 25 feet wide. Although very irregular, it is generally concordant to the foliation of the wallrock. Poor exposures and indistinct zoning make any estimation of resources questionable. Perthite crystals as large as 8 by 12 inches form about 30 percent of the plagioclaseperthite-quartz pegmatite of the wall zone. About 25 percent could be recovered by hand-cobbing. Fortyone beryl crystals measured in quartz-muscovite pegmatite of the core-margin zone indicate that the eastern half of the exposure contains about 0.3 percent beryl.

\section{LITERATURE CITED}

Bannerman, H. M., 1943, Structural and economic features of some New Hampshire pegmatites: New Hampshire Plan. and Devel. Comm., Mineral Resources Survey, pt. 7, 22 p.

Bannerman, H. M., and Cameron, E. N., 1946, The New England mica industry: Am. Inst. Mining Metall. Engineers Tech. Pub. 2024, 8 p.

Berman, Harry, 1927, Graftonite from a new locality in New Hampshire: Am. Mineralogist, v. 12, no. 4, p. 170-172.

Billings, M. P., Fowler-Billings, Katherine, Chapman, C. A., and Goldthwait, R. P., 1946, The geology of the Mount Washington quadrangle, New Hampshire: New Hampshire Plan. and Devel. Comm., 56 p.; Geol. Soc. America Bull., v. 57, no. 3, p. 261-273.

Blondel, F., and Lasky, S. G., 1956, Mineral reserves and mineral resources : Econ. Geology, v. 51, no. 7, p. 686-697. 
Cameron, E. N., Jahns, R. H., McNair, A. H., and Page, L. R., 1949, Internal structure of granitic pegmatites: Econ. Geology, Mon. 2, p. 61, 65.

Cameron, E. N., Larrabee, D. M., McNair, A. H., and others, 1954, Pegmatite investigations, 1942-45, New England: U.S. Geol. Survey Prof. Paper 255, 352 p.

Fleischer, Michael, and Cameron, E. N., 1946, Geochemistry of beryllium [report to Manhattan Project 1945, revised as MDDC-643, 1946] ; 1955, p. 80-92, in Quill, L. L., ed., The chemistry and metallurgy of miscellaneous materials: U.S. Atomic Energy Comm. TID-5212, U.S. Atomic Energy Comm. Tech. Inf. Service, Oak Ridge, Tenn.

Freedman, Jacob, 1950, Stratigraphy and structure of the Mt. Pawtuckaway quadrangle, southeastern New Hampshire: Geol. Soc. America Bull., v. 61, no. 5, p. 449-492.

Frondel, Clifford, 1941, Whitlockite; a new calcium phosphate, $\mathrm{Ca}_{3}\left(\mathrm{PO}_{4}\right)_{2}$ : Am. Mineralogist, v. 26, no. 3, p. 145-152.

Frondel, Clifford, and Lindberg, M. L., 1948, Second occurrence of brazilianite : Am. Mineralogist, v. 33, no. 3-4, p. 135-141.

Holden, E. F., 1918, Famous mineral localities; Beryl Mountain, Acworth, New Hampshire: Am. Mineralogist, v. 3, p. 199200.

Jackson, C. T., 1844, Final report on the geology and mineralogy of the State of New Hampshire: Concord, $376 \mathrm{p}$.

Jahns, R. H., 1955, The study of pegmatites: Econ. Geology, 50th Anniversary Volume, p. 1025-1130.

Levin, S. B., 1948, Beryl Mountain, Sullivan County, N. H.: U.S. Bur. Mines Rept. Inv. 4216, 3 p.

Meyers, T. R., 1941, New Hampshire minerals and mines: New Hampshire Plan. and Devel. Comm., Mineral Resources Rept., $49 \mathrm{p}$.

Moke, C. B., 1946, The geology of the Plymouth quadrangle, New Hampshire: New Hampshire Plan. and Devel. Comm., 21 p.

Norton, J. J., Griffitts, W. R., and Wilmarth, V. R., 1958, Geology and resources of beryllium in the United States: Internat. Conf. on the Peaceful Uses of Atomic Energy, 2d, Geneva, Proc., v. 2, p. 21-34.

Norton, J.J., and Page, L. R., 1956, Methods used to determine grade and reserves of pegmatites: Mining Eng., v. 8, no. 4, p. 401-414; Am. Inst. Mining and Metall. Engineers Trans., v. 205 , p. $401-414$.
Olson, J. C., 1950, Feldspar and associated pegmatite minerals in New Hampshire: New Hampshire Plan. and Devel. Comm., Mineral Resources Survey, pt. 14, 50 p.

Page, L. R., 1950, Uranium in pegmatites: Econ. Geology, v. 45, no. 1, p. 28 .

Page, L. R., and others, 1953, Pegmatite investigations 19421945, Black Hills, South Dakota: U.S. Geol. Survey Prof. Paper 247, 228 p.

Reno, Horace T., 1956, Beryllium, in U.S. Bureau of Mines, Mineral facts and problems: U.S. Bur. Mines Bull. 556, p. 95-101.

Roy, C. J., and Freedman, Jacob, 1944, Petrology of the Pawtuckaway Mountains, New Hampshire: Geol. Soc. America Bull., v. 55, no. 7, p. 905-919.

Shepard, C. U., 1830, Mineralogical journey in the northern parts of New England: Am. Jour. Sci., 1st ser., v. 17, p. 353-360; v. 18, p. 289-303.

Sterrett, D. B., 1915, Some deposits of mica in the United States: U.S. Geol. Survey Bull. 580, p. 72-74.

- 1923, Mica deposits of the United States: U.S. Geol. Survey Bull. 740, p. 130-133.

Switzer, George, 1938, The paragenesis of the Center Strafford, New Hampshire, pegmatite: Am. Mineralogist, v. 23, no. 11 p. 811-820.

Teschemacher, J. E., 1844, On the beryl from Acworth, New Hampshire: Boston Soc. Nat. History, Proc. v. 1, p. 191192.

1847 , On the occurrence of uranium in the beryl locality at Acworth, New Hampshire: Boston Jour. Nat. History, v. 5, p. 87-89.

U.S. Bureau of Mines, 1939-55, Beryllium, in Minerals Yearbook.

1953, Materials survey, beryllium: Rept. compiled for Natl. Security Resources Board by U.S. Bur. Mines with the cooperation of the U.S. Geol. Survey.

Verrow, H. J., 1940, New Hampshire pegmatites productive: Mineralogist, v. 8, no. 8, p. 329-330.

1941, Pegmatite minerals of the Palermo quarry, North Groton, N.H. : Rocks and Minerals, v. 16, no. 6, p. 208-211. 
. 
. 
